\title{
Alfred FORKE
}

\section{Introduction and Appendixes to}

\author{
WANG CH'UNG'S \\ LUN-HÊNG
}

Dans le cadre de la collection : "Les classiques des sciences sociales" fondée et dirigée par Jean-Marie Tremblay,

$$
\text { http://classiques.uqac.ca }
$$

Une collection développée en collaboration avec la Bibliothèque Paul-Émile Boulet de I'Université du Québec à Chicoutimi.

http://bibliotheque.uqac.ca 


\section{Lun-hêng}

\section{Politique d'utilisation de la bibliothèque des Classiques}

Toute reproduction et rediffusion de nos fichiers est interdite, même avec la mention de leur provenance, sans l'autorisation formelle, écrite, du fondateur des Classiques des sciences sociales, Jean-Marie Tremblay, sociologue.

Les fichiers des Classiques des sciences sociales ne peuvent sans autorisation formelle :

- être hébergés (en fichier ou page web, en totalité ou en partie) sur un serveur autre que celui des Classiques.

- servir de base de travail à un autre fichier modifié ensuite par tout autre moyen (couleur, police, mise en page, extraits, support, etc...),

Les fichiers (.html,.doc,.pdf.,.rtf,.jpg,.gif) disponibles sur le site Les Classiques des sciences sociales sont la propriété des Classiques des sciences sociales, un organisme à but non lucratif composé exclusivement de bénévoles.

Ils sont disponibles pour une utilisation intellectuelle et personnelle et, en aucun cas, commerciale. Toute utilisation à des fins commerciales des fichiers sur ce site est strictement interdite et toute rediffusion est également strictement interdite.

\section{L'accès à notre travail est libre et gratuit à tous les utilisateurs. C'est notre mission.}

Jean-Marie Tremblay, sociologue

Fondateur et Président-directeur général, LES CLASSIQUES DES SCIENCES SOCIALES. 
A. Forke, Introduction and Appendixes to Wang Ch'ung's

\section{Lun-hêng}

Un document produit en version numérique par Pierre Palpant, collaborateur bénévole,

Courriel : ppalpant@uqac.ca

à partir de :

LUN-HÊNG

Philosophical and miscellaneous essays of WANG CH'UNG,

[WANG CHONG, LUNHENG]

Traduits et annotés par Alfred FORKE (1867-1944)

Volume I, pages 1-64, 576-577; volume II, pages 419-498, de la réimpression par Paragon Book Gallery, New York, 1962. Premières éditions : vol. I : Leipzig 1906, Londres 1907 ; vol. II : Berlin, Londres 1911.

Police de caractères utilisée : Verdana, 10 et 9 points.

Mise en page sur papier format Lettre (US letter), $8.5^{\prime \prime} \times 11^{\prime \prime}$.

Édition complétée le 5 janvier 2008 à Chicoutimi, Québec. 
A. Forke, Introduction and Appendixes to Wang Ch'ung's

\section{Lun-hêng}

\section{O}

Preface

\section{Introduction}

1. The Life of Wang Ch'ung.

2. The Works of Wang Ch'ung.

3. Wang Ch'ung's Philosophy : Metaphysics - Physics - Ethics - Critique : Philosophers, Historians - Religion and Folklore.

4. Table of Contents of the Lun-hêng.

\section{Appendixes}

I. The Theory of the Five Elements and the Classifications based thereon, A Sketch of Chinese Natural Philosophy.

II. The Cycle of the Twelve Animals.

III. On some implements mentioned by Wang Ch'ung : Fans - Chopsticks Burning glasses and moon mirrors.

Comparative table of contents

Vol. I, Table of contents - Additional note

Vol. II, Table of contents - Postcript

Quotations 


\section{A. Forke, Introduction and Appendixes to Wang Ch'ung's \\ Lun-hêng}

\section{PREFACE}

p1.001 On the two principal philosophical Chinese systems, Confucianism and Taoism we are tolerably well informed by translations of the leading works and by systematical treatises. These two branches may be regarded as the most important, but it would be impossible to write a history of Chinese philosophy without paying special attention to the various heterodox philosophers, whose views do not agree with the current ideas of either Confucianists or Taoists. For that very reason they are often more interesting than the latter, living original thinkers, who disdain to resign themselves to merely iterating old stereotyped formulæ. Many of their tenets remind us of similar arguments propounded by various philosophical schools of the West. I have called attention to the Epicurean Yang Chu and to the Chinese Sophists (vid. Journ. of Peking Orient. Soc., vol. III, p. 203 and Journ. of China Branch of Royal Asiat. Soc., vol. XXXIV, p. 1) and now beg to place before the public a translation of the philosophical essays of Wang Ch'ung, whom we may well call a Materialist. As a first instalment I published, some years ago, a paper treating of Wang Ch'ung's ideas on Death and Immortality (Journ. of China Branch of Royal Asiat. Soc., vol. XXXI, p. 40). My lecture on the Metaphysics of Wang Ch'ung, held in 1899 before the East Asiatic of the Congress of Orientalists at Rome, has not been printed, the manuscript having been lost by the secretaries of the Section.

Although he has much in common with the Confucianists and still more with the Taoists, Wang Ch'ung's philosophy does not lack originality. He is an Eclectic, and takes his materials from wherever it suits him, but he has worked it into an elaborate system such as did not exist before Chu Hsi. Like a true philosopher he has reduced the multiplicity of things to some few fundamental principles, by which he explains every phenomenon. One or two leading ideas pervade his philosophy as 'Leitmotives'.

p1.002 The Lun-hêng is not a systematic digest of Wang Ch'ung's philosophy. Chinese philosophers like the Greeks before Aristotle have not yet learned the art of connecting their thoughts so as to form a complete system, 


\section{A. Forke, Introduction and Appendixes to Wang Ch'ung's \\ Lun-hêng}

in which each chapter is the logical sequence of the preceding one. But Wang Ch'ung has already made one step in this direction. Whereas the Analects and the works of Mencius, Lieh Tse and Chuang Tse are hardly anything else than collections of detached aphorisms, each chapter embracing the most heterogeneous subjects, each chapter of the Lun-hêng is a real essay, the theme of which is given first and adhered to throughout. But there is not much connection between the separate essays.

These essays are not all of equal value. Some may perhaps interest a Chinese, but are not calculated to enlist our interest. For this reason I have not translated the whole work, but made a selection. It comprises the philosophical essays, and of the others the most characteristic, enabling the reader to form an adequate idea of the author and his peculiarities. My chief aim has been to set forth Wang Ch'ung's philosophy. The introduction contains a sketch of his system, which I have attempted to abstract from his writings.

Of the 84 essays of the Lun-hêng I have translated 44. I have taken the liberty of arranging them more systematically than is done in the original, classing them under several heads as metaphysical, physical, critical, religious, and folklore. The division is not a strict one, because with many chapters it is doubtful, to which class they belong. Especially between metaphysics and physics it is difficult to draw a distinction, since purely physical questions are often treated metaphysically. From a table of contents of the Lun-hêng in its entirety the reader will learn the subject of those essays, which have not been translated, and by its help he can easily find the place, which each chapter takes in the original.

With the exception of the Autobiography and the two chapters on Confucius and Mencius translated by Hutchinson (China Review, vol. VII and VIII) the essays of Wang Ch'ung have not been put into any European language before. A Chinese commentary to the Lun-hêng does not exist. I hope that my translation may prove trustworthy. For any misunderstandings, which in Chinese and philosophical works particularly are unavoidable, I count upon the indulgence of my critics.

As far as lay in my power, I have endeavoured to trace the sources from 


\section{A. Forke, Introduction and Appendixes to Wang Ch'ung's Lun-hêng}

which Wang Ch'ung has quoted, which has not been 1.003 an easy task, and I have added such explanatory notes as to enable even persons not knowing Chinese to understand the text. For the many proper names the index at the end of the volume will be of advantage.

To my thinking, Wang Ch'ung is one of the most ingenious Chinese writers, a satirist like Lucien and an esprit fort like Voltaire, whose Lun-hêng well deserves the widest publicity. 


\section{A. Forke, Introduction and Appendixes to Wang Ch'ung's \\ Lun-hêng}

\section{INTRODUCTION}

\section{The Life of Wang Ch'ung}

p1.004 The principal data of Wang Ch'ung's life are furnished by his autobiography and by the biographical notice in chapter 79 p. 1 of the Hou Han-shu, the History of the Later Han Dynasty, which was written by Fan Yeh in the 5th cent. A. D. and commented on by Prince Chang Huai Hsien of the T'ang dynasty. There we read :

«Wang Ch'ung, whose style was Chung Jên, was a native of Shang-yü in Kuei-chi. His forefathers had immigrated from YuanCh'êng in the Wei circuit. As a boy he lost his father and was commended in his village for his filial piety. Subsequently he repaired to the capital, where he studied at the academy.

The book of Yuan Shan Sung says that Wang Ch'ung was a very precocious youth. After having entered the academy, he composed an essay on six scholars on the occasion of the emperor visiting the Imperial College.

His teacher was Pan Piao from Fu-fêng. He was very fond of extensive reading, but did not trouble much about paragraphs or sentences. His family being poor, he possessed no books. Therefore he used to stroll about the market-place and the shops in Loyang and read the books exposed there for sale. That which he had once read, he was able to remember and to repeat. Thus he had acquired a vast knowledge of the tenets of the various schools and systems. Having returned to his native place, he led a very solitary life as a teacher. Then he took office in the prefecture and was appointed secretary, but in consequence of frequent remonstrances with his superiors, disputes, and dissensions with his colleagues, he had to quit the service.

Wang Ch'ung had a strong penchant for discussions. At the outset, his arguments would often appear rather queer, but his p1.005 final conclusions were true and reasonable. Being convinced that the 


\section{A. Forke, Introduction and Appendixes to Wang Ch'ung's Lun-hêng}

ordinary savants stuck too much to the letter, and thus would mostly lose the true meaning, he shut himself up for meditation, and no longer observed the ceremonies of congratulation or condolence. Everywhere near the door, the windows, and on the walls he had his knives and pens placed, with which he wrote the Lun-hêng in 85 chapters containing over 200,000 words.

Yuan Shan Sung says in his book that at first the Lun-hêng written by Wang Ch'ung was not current in the central provinces. When T'sai Yung came to $W u$, he discovered it there, and used to read it secretly as a help to conversation. Afterwards Wang Lang became prefect of Kuei-chi, and likewise got into possession of the book. On his return to Hsü-hsia his contemporaries were struck with the great improvement of his abilities. Some one remarked that, unless he had met with some extraordinary person, he must have found some extraordinary book. They made investigations, and found out that in fact it was from the Lun-hêng that he had derived this advantage. Thereupon the Lun-hêng came into vogue. Pao $P^{\prime} u$ Tse relates that his contemporaries grudged T'sai Yung the possession of a rare book. Somebody searched for it in the hiding place behind his curtains, and there in fact found the Lun-hêng. He folded some chapters together in order to take them away, when T'sai Yung proposed to him that they should both keep the book, but not divulge its contents.

He explained the similarities and the diversities of the different classes of things, and settled the common doubts and errors of the time.

The governor Tung Ch'in made him assistant-magistrate. Later on he rose to the rank of a sub-prefect. Then he retired and returned home. A friend and fellow-countryman of his Hsieh I Wu addressed a memorial to the throne, in which he recommended Wang Ch'ung for his talents and learning.

In the book of Hsieh Ch'êng it is stated that in recommending Wang Ch'ung, Hsieh I Wu said that his genius was a natural gift and not acquired by learning. Even Mencius and Sun Ching in former times, or Yang Hsiung, Liu Hsiang, or Sse ma Chien more recently in the Han epoch could not surpass him.

Su Tung commanded a chamberlain to summon Wang Ch'ung into his presence, but owing to sickness, he could not go. When he was nearly seventy years of age, his powers began to decline. Then he wrote a book on 'Macrobiotics' in 16 chapters, and refraining from all desires and propensities, and avoiding all emotions, he kept himself alive, until in the middle of the Yung-yuan period, when he died of an illness at his home. 


\section{A. Forke, Introduction and Appendixes to Wang Ch'ung's \\ Lun-hêng}

p1.006 By his own testimony Wang Ch'ung was born in the third of the Chien-wu cycle, i. e. in A. D. 27, in Shang-yü-hsien, the present Shao-hsingfu of the province of Chekiang. His family had originally been residing in Yuan-ch'êng=Ta-ming-fu in Chihli. His father's name was Wang Sung. Owing to their violent temper his ancestors had several times been implicated in local feuds, which are still now of frequent occurrence in Fukien and Chekiang, and were compelled to change their domicile. Wang Ch'ung's critics are scandalized at his coolly telling us that his great-grandfather behaved like a ruffian during a famine, killing and wounding his fellow-people.

If Wang Ch'ung's own description be true, he must have been a paragon in his youth. He never needed any correction neither at the hands of his parents nor of his teachers. For his age he was exceptionally sedate and serious. When he was six years old, he received his first instruction, and at the age of 8 he was sent to a public school. There the teacher explained to him the Analects and the Shuking, and he read 1,000 characters every day. When he had mastered the Classics, one was astonished at the progress he made, so he naïvely informs us. Of his other attainments he speaks in the same strain and with the same conceit. The Hou Han-shu confirms that he was a good son.

Having lost his father very early, he entered the Imperial College at Loyang, then the capital of China. His principal teacher was the historian Pan Piao, the father of Pan $K u$, author of the History of the Former Han dynasty. In Loyang he laid the foundation of the vast amount of knowledge by which he distinguished himself later on, and became acquainted with the theories of the various schools of thought, many of which he vigorously attacks in his writings. His aim was to grasp the general gist of what he read, and he did not care so much for minor details. The majority of the scholars of his time conversely would cling to the words and sentences and over these minutiæ quite forget the whole. Being too poor to buy all the books required to satiate his hunger for knowledge, he would saunter about in the market-place and book-shops, and peruse the books exposed there for sale, having probably made some sort of agreement with the book-sellers, who may have taken an 


\section{A. Forke, Introduction and Appendixes to Wang Ch'ung's \\ Lun-hêng}

interest in the ardent student. His excellent memory was of great service to him, for he could remember, even repeat what he had once read. At the same time his critical genius developed. He liked to argue a point, and though his views often seemed paradoxical, his opponents could not but admit the justness of his arguments.

p1.007 Having completed his studies, Wang Ch'ung returned to his native place, where he became a teacher and lived a very quiet life. Subsequently he took office and secured a small position as a secretary of a district, a post which he also filled under a military governor and a prefect. At last he was promoted to be assistant-magistrate of a department. He would have us believe that he was a very good official, and that his relations to his colleagues were excellent. The Hou Han-shu, on the other hand, tells us that he remonstrated so much with his superiors and was so quarrelsome, that he had to leave the service. This version seems the more probable of the two. Wang Ch'ung was much too independent, much too outspoken, and too clever to do the routine business well, which requires clerks and secretaries of moderate abilities, or to serve under superiors, whom he surpassed by his talents. So he devoted himself exclusively to his studies. He lived in rather straitened circumstances, but supported his embarassments with philosophical equanimity and cheerfulness.

«Although he was poor and had not an acre to dwell upon, his mind was freer than that of kings and dukes, and though he had no emoluments counted by pecks and bushels, he felt, as if he had ten thousand chung to live upon. He enjoyed a tranquil happiness, but his desires did not run riot, and though he was living in a state of poverty, his energy was not broken. The study of ancient literature was his debauchery, and strange stories his relish.

He had a great admiration for superior men, and liked to associate with people rising above mediocrity. As long as he was in office and well off, he had many friends, but most of them abandoned him, when he had retired into private life.

In A. D. 86 Wang Ch'ung emigrated into the province of Anhui, where he was appointed sub-prefect, the highest post which he held, but two years 


\section{A. Forke, Introduction and Appendixes to Wang Ch'ung's \\ Lun-hêng}

only, for in 88 he gave up his official career, which had not been a brilliant one. The reason of his resignation this time seems to have been ill health.

So far Wang Ch'ung had not succeeded in attracting the attention of the emperor. An essay which he had composed, when the emperor had visited the college of Loyang, had passed unnoticed. In the year 76, when parts of Honan were suffering from great dearth, Wang Ch'ung presented a memorial to the Emperor Chang $\mathrm{Ti}$ in which he proposed measures to prohibit dissipation and extravagancies, and to provide for the time of need, but his suggestions were not accepted. He did not fare better with another antialcoholic memorial, in which he advocated the prohibition of p1.008 the use of spirits. When finally the Emperor became aware of Wang Ch'ung, it was too late. A friend and a countryman of his, Hsieh I Wu recommended him to the throne for his talents and great learning, saying that neither Mencius or Hsün Tse nor in the Han time Yang Hsiung, Liu Hsiang or Sse Ma Ch'ien could outshine him. The Emperor Chang Ti (76-88 A. D.) summoned him to his presence, but owing to his ill-health Wang Ch'ung had to decline the honour. His state had impaired so much, that already in 89 he thought that his end had come. But the next two years passed, and he did not die. He found even the time to write a book on 'Macrobiotics', which he put into practice himself, observing a strict diet and avoiding all agitations in order to keep his vital fluid intact, until he expired in the middle of the Yung-yuan period (89-104) about the year 97 . The exact year is not known.

\section{The Works of Wang Ch'ung.}

Wang Ch'ung's last work, the Yang-hsing-shu or Macrobiotics in 16 chapters, which he wrote some years before his death, has been mentioned. His first productions were the Chi-su-chieh-yi 'Censures on Common Morals' in 12 chapters and the Chêng-wu, a book on Government, both preceding his principal work, the Lun-hêng, in which they are several times referred to in the two biographical chapters.

Wang Ch'ung wrote his 'Censures' as a protest against the manners of his 


\section{A. Forke, Introduction and Appendixes to Wang Ch'ung's \\ Lun-hêng}

time with a view to rouse the public conscience. He was prompted to write this work by the heartlessness of his former friends, who abandoned him, when he was poor, and of the world in general. To be read and understood by the people, not the literati only, he adopted an easy and popular style. This appears to have been contrary to custom, for he thought it necessary to justify himself (p. 1.071).

The work on government owes its origin to the vain efforts of the Imperial Government of his time to administer the Empire. They did not see their way, being ignorant of the fundamental principles (p. 1.070). From the Chêng-wu the territorial officials were to learn what they needed most in their administration, and the people should be induced

« to reform and gratefully acknowledge the kindness of the government (p. 1.090).

p1.009 These three works : the Macrobiotics, the Censures on Morals, and the work on Government have all been lost, and solely the Lun-hêng has come down to us. Whereas the Chi-su-chieh-yi censures the common morals, the Lun-hêng=Disquisitions tests and criticises the common errors and superstitions, the former being more ethical, the latter speculative. Many of these errors are derived from the current literature, classical as well as popular. Wang Ch'ung takes up these books and points out where they are wrong. He avoids all wild speculations, which he condemns in others, so he says (p. 1.091). The Lun-hêng is not professedly a philosophical work, intended to set forth a philosophical system, but in confuting and contesting the views of others, Wang Ch'ung incidentally develops his own philosophy. In this respect there is a certain resemblance with the Theodicee of Leibniz, which, strictly speaking, is a polemic against Bayle. Wang Ch'ung's aim in writing the Lun-hêng was purely practical, as becomes plain from some of his utterances.

«The nine chapters of the Lun-hêng on Inventions, and the three chapters of the Lun-hêng on Exaggerations, says he, are intended to impress people, that they must strive for truthfulness.

Even such high metaphysical problems as that of immortality he regards from a practical point of view. Otherwise he would not write, as he does : 
A. Forke, Introduction and Appendixes to Wang Ch'ung's

\section{Lun-hêng}

«I have written the essays on Death and on the False Reports about Death to show that the deceased have no consciousness, and cannot become ghosts, hoping that, as soon as my readers have grasped this, they will restrain the extravagance of the burials and become economical (p. 1.090).

From a passage (Chap. XXXVIII) to the effect that the reigning sovereign was continuing the prosperity of Kuang Wu Ti (25-57 A. D.) and Ming Ti (5875) it appears that the Lun-hêng was written under the reign of the Emperor Chang Ti viz. between 76 and 89 A. D. From another remark that in the Chiang-jui chapter (XXX) the auspicious portents, of the Yuan-ho and Changho epochs (84-86 and 87-88) could not be mentioned, because of its being already completed, we may infer that the whole work was finished before 84 . Thus it must date from the years 76-84 A. D.

The Lun-hêng in its present form consists of 30 books comprising 85 chapters or separate essays. Ch'ien Lung's Catalogue (Sse-k'u-chüan-shuTsung-mu chap. 120 p. 1) shows that we do not possess the Lun-hêng in its entirety. In his autobiography Wang Ch'ung states that his work contains more than a hundred chapters (p. 1.078), consequently a number of chapters must have been lost. The 85 chapters mentioned above are enumerated in the index ${ }_{\text {p1.010 }}$ preceding the text, but of the 44th chapter 'Chao-chih' we have merely the title, but not the text so that the number of chapters really existing is reduced to 84 . The chapters exceeding 85 must have already been lost in the first centuries, for we read in the Hou Han-shu of the 5th cent. A. D. that Wang Ch'ung wrote the Lun-hêng in 85 chapters.

Some interesting data about the history of the text are furnished in another History of the Later Han Dynasty, the Hou Han-shu of Yuan Shan Sung of the Chin epoch (265-419 A. D.), who lived anterior to Fan Yeh, the author of the officially recognised History of the Later Han. Yuan Shan Sung's History was in 100 books (cf. Li tai ming hsien lieh nü shih hsing p'u chap. 44, p. 35 v.), but it has not been incorporated into the Twenty-four dynastic Histories. Yuan Shan Sung, whose work is quoted by several critics, informs us that at first the Lun-hêng was only current in the southern provinces of China where Wang Ch'ung had lived. There it was discovered by T'sai Yung 


\section{A. Forke, Introduction and Appendixes to Wang Ch'ung's \\ Lun-hêng}

(133-192 A. D.) a scholar of note from the north, but instead of communicating it to others, he kept it for himself, reading it secretly 'as a help to conversation' $i$. e. he plundered the Lun-hêng to be able to shine in conversation. Another scholar, Wang Lang of the 2 nd and $3 d$ cent. A. D. is reported to have behaved in a similar way, when he became prefect of Kueichi, where he found the Lun-hêng. His friends suspected him of having come into possession of an extraordinary book, whence he took his wisdom. They searched for it and found the Lun-hêng, which subsequently became universally known. The Taoist writer Ko Hung of the 4th cent. A. D., known as Pao P'u Tse, recounts that the Lun-hêng concealed by T'sai Yung was discovered in the same way. At all events T'sai Yung and Wang Lang seem to have been instrumental in preserving and transmitting the Lun-hêng.

In the History of the Sui dynasty (580-618 A. D.), Sui-shu chap. 34 p. $7 \mathrm{v}$., an edition of the Lun-hêng in 29 books is mentioned, whereas we have 30 books now. The commentary to this passage observes that under the Liang dynasty (502-556 A. D.) there was the Tung-Hsü in 9 books and 1 book of Remarks written by Ying Fêng, but that both works are lost. They seem to have been treatises on the Lun-hêng, of which there are none now left. The Catalogue of the Books in the History of the T'ang dynasty (Ch'ien T'ang-shu chap. 47 p. 8) has the entry : 'Lun-hêng 30 books'.

At present the Lun-hêng forms part of the well known collection of works of the Han and Wei times, the Han Wei ts'ung-shu dating from the Ming dynasty. The text of the Lun-hêng ${ }_{\mathrm{p} 1.011}$ contained in the large collection of philosophical works, the Tse shu po chia, is only a reprint from the Han Wei Tsung-shu. In his useful little biographical index, Shu-mu ta-wên, Chang Chih Tung records a separate edition of the Lun-hêng printed under the Ming dynasty. I have not seen it and do not know, whether it is still to be found in the book-shops, and whether it differs from the current text. In the many quotations from the Lun-hêng of the T'ai p'ing Yü lan (9th cent. A. D.) there is hardly any divergence from the reading of our text. A commentary to the Lun-hêng has not been written.

In the appreciation of his countrymen Wang Ch'ung does not rank very high. Chao Kung Wu (12th cent. A. D.) opines that the Lun-hêng falls short of 


\section{A. Forke, Introduction and Appendixes to Wang Ch'ung's \\ Lun-hêng}

the elegant productions of the Former Han epoch. Another critic of the 12th cent., Kao Sse Sun is still more severe in his judgrnent. He declares the Lunhêng to be a medley of heterogeneous masses, written in a bad style, in which morality does not take the place it ought. After his view the Lun-hêng would have no intrinsic value, being nothing more than a 'help to conversation'. Wang Po Hou and others condemn the Lun-hêng on account of the author's impious utterances regarding his ancestors and his attacks upon the Sage Confucius. That he criticised Mencius might be excused, but to dare to find fault with Confucius is an unpardonable crime. That mars the whole work.

In modern times a change of opinion in favour of Wang Ch'ung seems to have taken place. In his Prefatory Notice to the Lun-hêng, Yu Chun Hsi pours down unrestricted praise upon him.

« People of the Han period, he remarks, were fond of fictions and fallacies. Wang Ch'ung pointed out whatever was wrong; in all his arguments he used a strict and thorough method, and paid special attention to meanings. Rejecting erroneous notions he came near the truth. Nor was he afraid of disagreeing with the worthies of old. Thus he furthered the laws of the State, and opened the eyes and ears of the scholars. People reading his books felt a chill at first, but then they repudiated all falsehood, and became just and good. They were set right, and discarded all crooked doctrines. It is as if somebody amidst a clamouring crowd in the market-place lifts the scale : then the weights and prices of wares are equitably determined, and every strife ceases.

To a certain extent at least the Ch'ien Lung Catalogue does him justice, while characterising his strictures on Confucius and Mencius and his disrespect towards his forefathers as wicked and perverse, its critics still admit that in exposing falsehoods and denouncing what is base and low he generally hits the truth, and 1.012 that by his investigations he has done much for the furtherance of culture and civilization. They conclude by saying that, although Wang Ch'ung be impugned by many, he will always have admirers. 


\section{A. Forke, Introduction and Appendixes to Wang Ch'ung's \\ Lun-hêng}

I presume that most Europeans, untramelled by Chinese moral prejudices, will rather be among his admirers, and fall in with Mayers speaking of Wang Ch'ung as 'a philosopher, perhaps the most original and judicious among all the metaphysicians China has produced,... who in the writings derived from his pen, forming a work in thirty books, entitled Critical Disquisitions 'Lunhêng', handles mental and physical problems in a style and with a boldness unparallelled in Chinese literature' (Reader's Manual N. 795).

The first translator of the two chapters on Confucius and Mencius and of the autobiography, Hutchinson, says of the Lun-hêng:

« The whole book will repay perusal, treating as it does of a wide Tange of subjects, enabling us to form some idea of the state of the Chinese mind at the commencement of the Christian era.

The subjects (treated) are well calculated to enlist the interest of the student and would most probably shed much light upon the history of Chinese Metaphysics (China Review vol. VII, p. 40).

In my opinion Wang Ch'ung is one of the greatest Chinese thinkers. As a speculative philosopher he leaves Confucius and Mencius, who are only moralists, far behind. He is much more judicious than Lao Tse, Chuang Tse, or Mê Ti. We might perhaps place him on a level with Chu Hsi, the great philosopher of the Sung time, in point of abilities at least, for their philosophies differ very much.

In most Chinese works Wang Ch'ung is placed among the Miscellaneous Writers or the Eclectics 'Tsa Chia', who do not belong to one single school, Confucianism, Mêhism, or Taoism, but combine the doctrines of various schools. Wang Ch'ung is treated as an Eclectic in the histories of the Sui dynasty and the T'ang dynasty, in Ch'ien Lung's Catalogue, and in the Tseshu po-chia. Chang Chih Tung, however, enumerates him among the Confucianists, and so does Faber (Doctrines of Confucius p.31). Although he has not been the founder of a school, I would rather assign to him a place apart, to which his importance as a philosopher entitles him. It matters not that his influence has been very slight, and that the Chinese know so little of him. His work is hardly read, but is extensively quoted in dictionaries and cyclopedias. At any rate Wang Ch'ung is more of an Eclectic than a 


\section{A. Forke, Introduction and Appendixes to Wang Ch'ung's \\ Lun-hêng}

Confucianist. The Chinese p1.013 qualify as 'Tsa Chia' all those original writers whom they cannot place under any other head. Wang Ch'ung seems to regard himself as a Confucianist. No other philosopher is more frequently mentioned by him than Confucius, who, though he finds fault with him here and there, is still, in his eyes, the Sage. Wang Ch'ung is most happy, when he can prove an assertion by quoting the authority of Confucius. This explains how he came to be classed by others with the Confucianists.

\section{Wang Ch'ung's Philosophy}

At first sight Wang Ch'ung's philosophy might seem dualistic, for he recognises two principles, which are to a certain extent opposed to each other, the Yang and the Yin fluid. But, although the former, which is conceived as forming heaven as well as the human mind, be more subtle than the latter, from which the earth has been created, yet it is by no means immaterial. Both these principles have been evolved from Chaos, when the original fluid became differentiated and split into two substances, a finer one, Yang, and a coarser one, Yin. We do not find a purely spiritual or transcendent correlate to these two substances such e. g. as Tao, the allembracing mystical force of the Taoists, or Li 'Reason', which in Chu Hsi's system rules over Matter ' $C h^{\prime} i$ ', and thus makes this system truly dualistic. Even Fate, which takes such a prominent place in Wang Ch'ung's philosophy, has been materialised by him, and it is hardly anything more than a sort of a natural law. We cannot be far wrong, if we characterise his philosophy as a materialistic monism.

Compared with western thought Wang Ch'ung's system bears some resemblance to the natural philosophy of Epicurus and Lucretius. In the East we find some kindred traits among the Indian materialists, the Chârvâkas.

Epicurus attaches great importance to physics. The knowledge of the natural causes of things shall be an antidote against superstitions. Wang Ch'ung likewise takes a lively interest in all physical problems, and tries to base his arguments on experience, as far as possible. He wishes to explain all 


\section{A. Forke, Introduction and Appendixes to Wang Ch'ung's \\ Lun-hêng}

natural phenomena by natural causes. His method is quite modern. If he often falls into error nevertheless, it is not so much owing to bad reasoning as to the p1.014 poor state of Chinese science at his time. He regards many things as proved by experience, which are not, and in spite of his radicalism has still too much veneration for the sayings of old classical authors.

Wang Ch'ung's views agree, in many respects, with the Epicurean Physics, but not with its Eudæmonology and Sensualism, his Ethics being totally different. Ethical Epicureanism has its representative in China in the preChristian philosopher Yang Chu, who seems to have concerned himself with Ethics exclusively, whereas Wang Ch'ung has especially devoted himself to the study of metaphysical and physical questions. The professed aim of the philosophy of Epicurus is human happiness. By delivering them from errors and superstitions he intends to render people happy. Wang Ch'ung likewise hopes to do away with all inventions, fictions, and falsehoods, but in doing so he has truth, and not so much happiness in view.

a) Metaphysics.

The pivots of Wang Ch'ung's philosophy are Heaven and Earth, which have been formed of the two fluids, Yang and Yin.

« The fluids of the Yin and Yang, he says, are the fluids of Heaven and Earth (Chap. XXX).

These two principles are not of Wang Ch'ung's invention, they are met with in ancient Chinese literature, in the Yiking and the Liki for instance (see Tchou $\mathrm{Hi}$, Sa Doctrine et son influence, par S. Le Gall, Chang-hai 1894, p. 35).

Earth is known to us, it has a material body like man (p. 1.093), but what are we to understand by Heaven ? Is it a spirit, the Spirit of Heaven or God, or merely an expanse of air, the Blue Empyrean, or a substance similar to that of Earth ? Wang Ch'ung considers all these possibilities and decides in favour of the last.

«Men are created by heaven, why then grudge it a body ? he asks. 


\section{A. Forke, Introduction and Appendixes to Wang Ch'ung's \\ Lun-hêng}

« Heaven is not air, but has a body on high and far from men (Chap. XIX).

« To him who considers the question, as we have done, it becomes evident that heaven cannot be something diffuse and vague.

His reasons are that heaven has a certain distance from earth, which by Chinese mathematicians has been calculated at upwards of $60,000 \mathrm{Li}$, and that the constellations known as the solar mansions are attached to it. These arguments seem strange to us now, but we must bear in mind that the Greeks, the Babylonians, and the Jews held quite similar views, regarding heaven as an iron or a brazen vault, the 'firmament' to which the sun, the moon, and the stars were fixed, or supposing even quite a number of celestial spheres one above the other, as Aristotle does.

p1.015 With regard to the origin of the universe Wang Ch'ung simply adopts the old creation theory, on which he writes as follows :

«The commentators of the Yiking say that previous to the separation of the primogenial vapours, there was a chaotic and uniform mass, and the books of the Literati speak of a wild medley, and of air not yet separated. When it came to be separated, the pure elements formed heaven, and the impure ones, earth. According to the expositors of the Yiking and the writings of the Literati the bodies of heaven and earth, when they first became separated, were still small, and they were not far distant from each other (loc. cit.).

In conformity with this view Heaven and Earth were originally one viz. air or vapour. This theory must be very old, for it is already alluded to in the Liki, and the Taoist philosopher Lieh Tse of the 5th cent. B. C., who gives the best exposition of it, seems to refer it to the sages of former times. The passage is so interesting, that I may be permitted to quote it in full :

« The teacher Lieh Tse said : The sages of old held that the Yang and the Yin govern heaven and earth. Now, form being born out of the formless, from what do heaven and earth take their origin ? It is said: There was a great evolution, a great inception, a great 


\section{A. Forke, Introduction and Appendixes to Wang Ch'ung's \\ Lun-hêng}

beginning, and a great homogeneity. During the great evolution, Vapours were still imperceptible, in the great inception Vapours originate, in the great beginning Forms appear, and during the great homogeneity Substances are produced.

The state when Vapours, Forms, and Substances though existing were still undivided, is called Chaos, which designates the conglomeration and inseparability of things. 'They could not be seen though looked at, not be heard though listened to, and not be attained though grasped at', therefore one speaks of (incessant) evolution. Evolution is not bound to any forms or limits.

Evolution in its transformations produces one, the changes of one produce seven, the changes of seven produce nine. Nine is the climax, it changes again, and becomes one. With one forms begin to change.

The pure and light matter becomes the heaven above, the turbid and heavy matter forms the earth below. The mixture of their fluids gives birth to man, and the vitalizing principle of heaven and earth creates all beings (Lieh Tse I, 2).

In the Liki we read :

« Propriety must have sprung from the Great One. This by division became Heaven and Earth, and by transformation the Yin and the Yang (Legge's Liki, Vol. I, p. 386).

p1.016 It is curious to note the similarity of the Epicurean cosmogony with that of the ancient Chinese. Lucretius sings :

«Quippe etenim primum terrai corpora quæque, propterea quod erant gravia et perplexa, coibant in medio atque imas capiebant omnia sedes; quæ quanto magis inter se perplexa coibant, tam magis expressere ea quæ mare sidera solem lunamque efficerent et magni mœnia mundi : omnia enim magis hæc e levibus atque rotundis seminibus multoque minoribus sunt elementis 


\section{A. Forke, Introduction and Appendixes to Wang Ch'ung's \\ Lun-hêng}

quam tellus, ideo, per rara foramina, terræ partibus erumpens primus se sustulit æther ignifer et multos secum levis abstulit ignis.

and further on :

« Sic igitur terræ concreto corpore pondus constitit, atque omnis mundi quasi limus in imum confluxit gravis et subsedit funditus ut fæx ; inde mare, inde aër, inde æther ignifer ipse corporibus liquidis sunt omnia pura relicta et leviora aliis alia, et liquidissimus æther atque levissimus aërias super influit auras, nec liquidum corpus turbantibus aëris auris commiscet.

$$
\text { (Lucr. V, 439-449; 485-493.) }
$$

The principle of division is the same : the light primary bodies Wang Ch'ung and the Chinese cosmogonists term Yang, the heavy ones they designate by Yin. Only in respect of the line of demarcation the Epicureans and the Chinese differ, for, whereas the former regard earth alone as heavy and water, air and ether as light matter, the Chinese comprise earth and water under the term Yin, and air and fiery ether under Yang. From various utterances of Wang Ch'ung it would appear that he conceives the Yang as a fiery and the Yin as a watery element, in short that Yang is fire and Yin water. This would tolerably well account for the formation of the universe. Fire forms the sun, the moon, and the other luminaries of Heaven, while from water and its sediments Earth, the oceans, and the atmosphere are developed.

«The solar fluid is identical with the heavenly fluid (Chap. XVIII), says Wang Ch'ung,

and :

« Rain is Yin, and brightness Yang, and conversely cold is Yin, and warmth is Yang' (Chap. XXI).

The other attributes given by Wang Ch'ung to the Yang and the Yin principles are merely the qualities of fire and water. The ${ }_{\mathrm{p} 1.017}$ Yang, the fiery ether or the solar fluid, is bright, i. e. light (Chap. XX), warm (Chap. XXI), dry 


\section{A. Forke, Introduction and Appendixes to Wang Ch'ung's \\ Lun-hêng}

(Chap. XVIII), vivifying, and creative (Chap. XXI). The Yin, rain or water, is dark, cold, wet, and destructive (p. 1.111). By itself water possesses neither light nor warmth, and may well be called dark and cold.

There is not a strict separation of the fluids of Heaven and Earth, they often mix and permeate one another. Heaven as well as Earth enclose air (Chap. XIX). The immense mass of air forming the gaseous part of Heaven, which, as we have seen, is credited with a body, is called sky (p. 1.113).

Now, whereas Earth rests motionless in the centre of the world, Heaven revolves around it, turning from east to west. This movement is explained as the emission of the heavenly fluid which, however, takes place spontaneously. Spontaneity is another corner-stone of Wang Ch'ung's system. It means that this movement is not governed by any intelligence or subservient to the purposes of any spiritus rector, but is solely regulated by its own inherent natural laws. The same idea is expressed in Mâdhavâcharya's Sarva-Darśana Sangraha :

« The fire is hot, the water cold, refreshing cool the breeze of morn). By whom came this variety ? From their own nature was it born.

(Sarva-Darśana Sangraha, translated by E. B. Cowell and A. E. Gough, London 1882, p. 10.)

Wang Ch'ung admits that he has adopted the principle of spontaneity from the Taoists, who however, have not sufficiently substantiated it by proofs ( $p$. 1.097). He shows that Heaven cannot display a conscious activity like man, because such activity is evoked by desires and impulses, which require organs: the eye, the mouth, etc. The heavenly fluid is not a human body with eyes and ears, but a formless and insensible mass (p. 1.093). The observation of the natural growth of plants and of the regularity of other natural phenomena precluding the idea of special designed acts, has confirmed our philosopher in his belief in spontaneity.

« The principle of Heaven is inaction, he says. Accordingly in spring it does not do the germinating, in summer the growing, in autumn the ripening, or in winter the hiding of the seeds. When the Yang 


\section{A. Forke, Introduction and Appendixes to Wang Ch'ung's \\ Lun-hêng}

fluid comes forth spontaneously, plants will germinate and grow of themselves and, when the Yin fluid rises, they ripen and disappear of their own accord (p. 1.099).

The movement of the Yin fluid is spontaneous likewise.

« Heaven and Earth cannot act, nor do they possess any p1.018 knowledge (p. 1.101).

They are not inert, but their activity is unintentional and purposeless. Thus spontaneity is the law of nature.

From this point of view Wang Ch'ung characterises the fluid of Heaven as

«placid, tranquil, desireless, inactive, and unbusied (p. 1.093),

all attributes ascribed by the Taoists to their Mundane Soul, Tao.

At all times Heaven has been personified and deified. With the Chinese as well as with us Heaven has become a synonym for God. Wang Ch'ung notices that human qualities have been attributed to him. We see in him the Father of Mankind, the Chinese an emperor, the 'Supreme Ruler', Shang Ti. He lives in heaven like a king in his palace, and governs the world (Chap. XXII) meting out rewards and punishments to mankind, rewarding the virtuous (p. 1.160), and punishing the wicked (p. 1.134). He reprimands the sovereigns on earth for their misrule by means of extraordinary natural phenomena, and, unless they reform, visits them and their people with misfortune (p. 1.126). Thunder is his angry voice, and with his thunderbolt he strikes the guilty (Chap. XXII).

Regarding Heaven as nothing else than a substance, a pure and tenuous fluid without a mind, Wang Ch'ung cannot but reject these anthropomorphisms. Heaven has no mouth, no eyes ; it does not speak nor act (p. 1.183), it is not affected by men (p. 1.110), does not listen to their prayers ( $p .1 .113$ ), and does not reply to the questions addressed to it ( $p$. $1.184)$.

By a fusion of the fluids of Heaven and Earth all the organisms on earth have been produced (p. 1.104). Man does not make an exception. In this respect Heaven and Earth are like husband and wife, and can be regarded as the father and the mother of mankind (Chap. XX). The same idea has been 


\section{A. Forke, Introduction and Appendixes to Wang Ch'ung's \\ Lun-hêng}

enunciated by Lucretius :

« Postremo pereunt imbres, ubi eos pater æther

in gremium matris terrai præcipitavit :

at nitidæ surgunt fruges, ramique virescunt

arboribus, crescunt ipsæ fetuque gravantur.

(Lucr. I, 250-253.)

and further on :

« Denique cælesti sumus omnes semine oriundi :

omnibus ille idem pater est, onde alma liquentis

umoris guttas mater cum terra recepit,

feta parit nitidas fruges arbustaque læta,

et genus humanum parit, omnia sæcula ferarum,

pabula cran præbet, quibus omnes corpora pascunt

et dulcem ducunt vitam prolemque propagant ;

quapropter merito maternum nomen adeptast'.

(Lucr. II, 988-995.)

p1.019 Wang Ch'ung compares the creation of man to the freezing of ice. He is the produce of the mixture and concretion or crystallization of the two primary fluids :

« During the chilly winter months the cold air prevails, and water turns into ice. At the approach of spring, the air becomes warm, and the ice melts to mater. Man is born in the universe, as ice is produced so to speak. The Yang and the Yin fluids crystallize, and produce man. When his years are completed, and his span of life comes to its end, he dies and reverts to those fluids (p. 1.196).

The Yin forms the body, and the Yang produces the vital spirit and the mind. Both are identical, Wang Ch'ung does not discriminate between the anima and the animus :

« That by which man is born are the Yang and the Yin fluids; the Yin fluid produces his bones and flesh, the Yang fluid the vital spirit. While man is alive, the Yang and Yin fluids are in order. Hence bones and flesh are strong, and the vital force is full of 


\section{A. Forke, Introduction and Appendixes to Wang Ch'ung's \\ Lun-hêng}

vigour. Through the vital force he has knowledge, and with his bones and flesh he displays strength. The vital spirit can speak, the body continues strong and robust. While bones and flesh and the vital spirit are entwined and linked together, they are always visible and do not perish (Chap. XVIII).

Man is imbued with the heavenly or vital fluid at his birth. It is a formless mass like the yolk of an egg, before it is hatched, showing in this respect the nature of the primogenial vapours, from which it has been derived (p. 1.199). There is no difference between the vital forces of man and animals. They have the same origin. The vital fluid resides in the blood and the arteries, and is nourished and developed by eating and drinking (p. 1.194). It has to fulfil two difficult functions, to animate the body and keep it alive, and to form its mind. All sensations are caused by the vital fluid :

«When the vital fluid is thinking or meditating, it flows into the eyes, the mouth or the ears. When it flows into the eyes, the eyes see shapes, when it flows into the ears. the ears hear sounds, and, when it flows into the mouth, the mouth speaks something (Chap. XVIII).

Wang Ch'ung imagines that all sensations are produced in their organs by the vital fluid, which must be the mental power as well, since it thinks and meditates. Insanity is defined as a disturbance of the vital force (eod.). There are no supernatural mental faculties and no prophets or sages knowing the future or possessing a special knowledge derived from any other source than the vital force ( $p .1 .061$ ). It is also the will, which causes the mouth to speak. As such it determines the character, p1.020 which in Wang Ch'ung's belief depends upon its quantity (Chap. XXXI). As vital energy it modifies the length of human life, which ceases, as soon as this energy is used up (Chap. XXVII).

From what our author says about ghosts and spirits in particular, which consist of the Yang fluid alone without any Yin, we can infer that he conceived of the human soul also as an aura, a warm breath identical to a certain extent with the solar fluid.

It is easy to see, how the Chinese came to denote the body as Yin and the soul as Yang - I believe that these notions were already current at Wang 


\section{A. Forke, Introduction and Appendixes to Wang Ch'ung's \\ Lun-hêng}

Ch'ung's time, who only took them up. The body is formed of a much coarser stuff than the soul, consisting as it does of solid and liquid matter. Therefore they presume that it must have been produced from the heavier and grosser substance, the Yin, while the purer and lighter Yang formed the soul. A living body is warm, warmth is a quality of the Yang fluid, consequently the vital force must be Yang. The mind enlightens the body, the Yang fluid is light as well, ergo the mind is the Yang fluid. The last conclusion is not correct, the mind not being a material light, but a Chinese would not hesitate to use such an analogy; their philosophy abounds with such symbolism.

The ideas of the Epicureans on the nature of the soul agree very well with Wang Ch'ung's views. According to Epicurus the soul is a tenuous substance resembling a breath with an admixture of some warmth, dispersed through the whole organism :

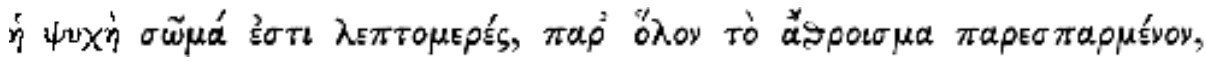

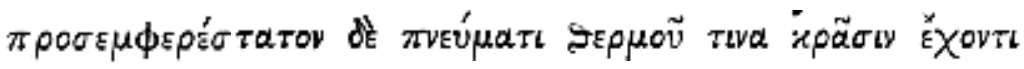

(Diog. Laert. X, 63).

Elsewhere the soul is described as a mixture of four substances : a fiery, an aeriform, a pneumatical, and a nameless one, which latter is said to cause sensations :

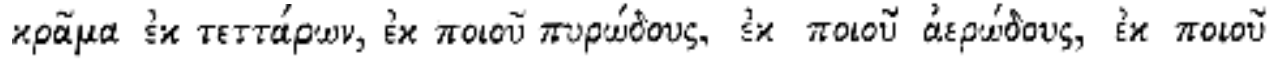

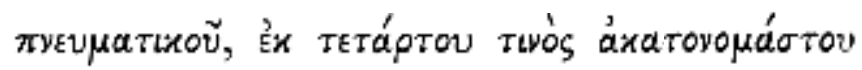

(Plut. Plac. IV, 3).

Lucretius says that the soul consists of much finer atoms than those of water, mist or smoke, and that it is produced, grows, and ages together with the body (Lucr. III, 425-427, 444-445). When a man dies, a fine, warm, aura leaves his body (III, 232).

As regards man's position in nature Wang Ch'ung asserts that he is the noblest and most intelligent creature, in which the mind of Heaven and Earth reach their highest development (Chap. XLIII); still he is a creature like others, and there exists no fundamental difference between him and other animals (p. 1.202). Wang Ch'ung likes to insist upon the utter insignificance of man, when compared with the immense grandeur of Heaven and Earth. It 


\section{A. Forke, Introduction and Appendixes to Wang Ch'ung's \\ Lun-hêng}

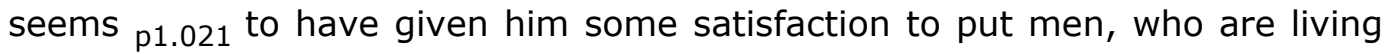
on Earth, on a level with fleas and lice feeding upon the human body, for we find this drastic simile, which cannot have failed to hurt the feelings of many of his self-sufficient countrymen, repeated several times (p. 1.183, Chap. XXVI). In short, according to Wang Ch'ung man does not occupy the exceptional position in the world which he uses to vindicate for himself. He has not been created on purpose, as nothing else has, the principle of nature being chance and spontaneity (p. 1.103). The world has not been created for the sake of man.

«Some people, remarks Wang Ch'ung, are of opinion that Heaven produces grain for the purpose of feeding mankind, and silk and hemp to clothe them. That would be tantamount to making Heaven the farmer of man or his mulberry girl, it would not be in accordance with spontaneity (p. 1.092).

As an argument against the common belief that Heaven produces his creatures on purpose, he adduces the struggle for existence, for says Wang Ch'ung :

« If Heaven had produced its creatures on purpose, he ought to have taught them to love each other, and not to prey upon and destroy one another. One might object that such is the nature of the five elements that, when Heaven creates all things, it imbues them with the fluids of the five elements, and that these fight together and destroy one another. But then Heaven ought to have filled its creatures with the fluid of one element only, and taught them mutual love, not permitting the fluids of the five elements to resort to strife and mutual destruction (p.104).

Here again Wang Ch'ung is in perfect accord with the Epicureans. Epicurus asserts that nothing could be more preposterous than the idea that nature has been regulated with a view to the well-being of mankind or with any purpose at all. The world is not as it ought to be, if it had been created for the sake of man, for how could Providence produce a world so full of evil, where the virtuous so often are maltreated and the wicked triumph? (Zeller, Philosophie der Griechen, III. Teil, I. Abt., 1880, pp. 398 seq. and 428.) 


\section{A. Forke, Introduction and Appendixes to Wang Ch'ung's \\ Lun-hêng}

The same sentiment finds expression in the following verses of the Epicurean poet :

Nam quamvis rerum ignorem primordia quæ sint, hoc tamen ex ipsis cæli rationibus ausim confirmare aliisque ex rebus reddere multis, nequaquam nobis divinitus esse creatam naturam mundi : tanta stat prædita culpa.

(Lucr. II, 177-181 and V, 185-189.)

p1.022 Although man owes his existence to the Yang and the Yin fluids, as we have seen, he is naturally born by propagation from his own species. Heaven does not specially come down to generate him. All the stories of supernatural births recorded in the Classics, where women were specially fecundated by the Spirit of Heaven, are inventions (p. 1.048). Human life lasts a certain time, a hundred years at most, then man dies (p. 1.046). A prolongation of life is impossible, and man cannot obtain immortality ( $p$. 1.050) :

«Of all the beings with blood in their veins, says our philosopher, there are none but are born, and of those endowed with life there are none but die. From the fact that they were born, one knows that they must die. Heaven and Earth were not born, therefore they do not die. Death is the correlate of birth, and birth the counterpart of death. That which has a beginning must have an end, and that which has an end, must necessarily have a beginning. Only that which is without beginning or end, lives for ever and never dies (Chap. XXVIII).

To show that the human soul is not immortal and does not possess any personal existence alter death Wang Ch'ung reasons as follows : During life the Yang fluid, $i$. e. the vital spirit or the soul, adheres to the body, by death it is dispersed and lost. By its own nature this fluid is neither conscious, nor intelligent, it has no will and does not act, for the principle of the Yang or the heavenly fluid is unconsciousness, inaction, and spontaneity. But it acquires mental faculties and becomes a soul by its temporary connection with a body. The body is the necessary substratum of intelligence, just as a fire requires a 


\section{A. Forke, Introduction and Appendixes to Wang Ch'ung's \\ Lun-hêng}

substance to burn. By death

« that which harbours intelligence is destroyed, and that which is called intelligence disappears. The body requires the fluid for its maintenance, and the fluid the body to become conscious. There is no fire in the world burning quite of itself, how could there be an essence without a body, but conscious of itself ( $p .1 .195$ ).

The state of the soul after death is the same as that before birth.

«Before their birth men have no consciousness. Before they are born, they form part of the primogenial fluid, and when they die, they revert to it. This primogenial fluid is vague and diffuse, and the human fluid a part of it. Anterior to his birth, man is devoid of consciousness, and at his death he returns to this original state of unconsciousness, for how should he be conscious ? (p. 1.194.)

Wang Ch'ung puts forward a number of arguments against immortality. If there were spirits of the dead, they would certainly manifest themselves. They never do, consequently there are none p1.023 (p. 1.193). Other animals do not become spirits after death, wherefore should man alone be immortal, for though the most highly organised creature, still he is a creature and falls under the general laws (p. 1.191). The vital spirit or soul is affected by external influences, it grows by nourishment, relaxes, and becomes uncouscious by sleep, is deranged and partly destroyed by sickness, and the climax of sickness, death, which dissolves the body, should not affect it at all ? (p. 1.196.)

At all times the dogma of immortality has been negatived by materialistic philosophers. The line of arguments of the Greek as well as the Indian materialists is very much akin to that of Wang Ch'ung.

Epicurus maintains that, when the body decays, the soul becomes scattered, and loses its faculties, which cannot be exercised in default of a body :

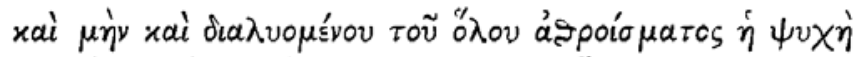

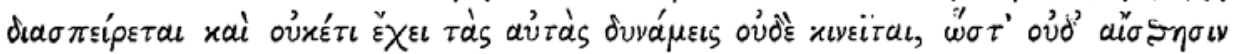

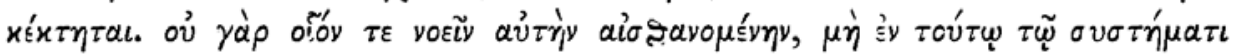

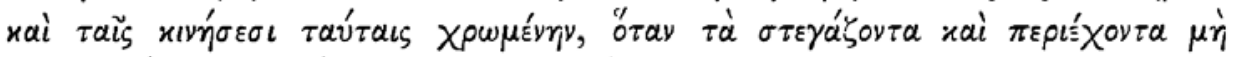

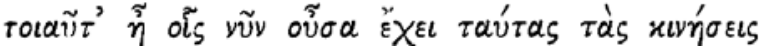




\section{A. Forke, Introduction and Appendixes to Wang Ch'ung's \\ Lun-hêng}

(Diog. Laert. X, 65-66)

He adds that an immaterial essence can neither act nor suffer, and that it is foolish to say that the soul is incorporeal :

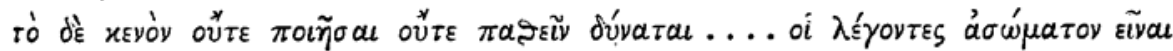

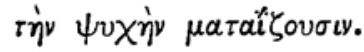

From the fact that the vital fluid is born with the body, that it grows, develops, and declines along with it, Lucretius infers that the fluid must also be dissolved simultaneously with the body, scattered into the air like smoke :

« ergo dissolvi quoque convenit omnem animai

naturam, ceu fumus, in altas aëris auras ;

quandoquidem gigni pariter pariterque videmus

crescere et, ut docui, simul ævo fessa fatisci'.

(Lucr. III, 455-458.)

What Wang Ch'ung asserts about the influence of sickness on the soul ( $p$. 1.196), Lucretius expresses in the following pathetic verses:

«Quin etiam morbis in corporis avius errat sæpe animus : dementit enim deliraque fatur, interdumque gravi lethargo fertur in altum æternumque soporem oculis nutuque cadenti ; unde neque exaudit votes nec noscere voltus illorum potis est, ad vitam qui revocantes circum stant lacrimis rorantes ora genasque, quare animum quoque dissolvi fateare necessest, quandoquidem penetrant in eum contagia morbi.

(Lucr. III, 463-471.)

p1.024 The interaction of body and mind, which thrive only, as long as they are joined together, and both decay, when they have been separated, the poet describes as follows :

«Denique corporis atque animi vivata potestas inter se coniuncta valent vitaque fruuntur : nec sine corpore enim vitalis edere motus sola potest animi per se natura nec autem cassum animi corpus durare et sensibus uti. 


\section{A. Forke, Introduction and Appendixes to Wang Ch'ung's \\ Lun-hêng}

(Lucr. III, 556-560.)

As the tree does not grow in the sky, as fish do not live on the fields, and as blood does not run in wood, thus the soul cannot reside anywhere else than in the body, not in the clods of earth, or in the fire of the sun, or in the water, or in the air (Lucr. V, 133-134) and, when the body dies, it must become annihilated likewise.

« Denique in æthere non arbor, non æquore salso

nubes esse queunt, nec pistes vivere in arvis,

nec cruor in lignis neque saxis sucus inesse.

certum ac dispositumst ubi quicquid crescat et insit.

sic animi natura nequit sine corpore oriri

sola neque a nervis et sanguine longiter esse.

(Lucr. III, 781-786.)

« quare, corpus ubi interiit, periisse necessest

confiteare animam distractam in corpore toto.

(Loc. cit. 795-796.)

Of the Chârvâkas it is said by Sankara that

« seeing no soul, but body, they maintain the non-existence of soul other than body.

«Thought, knowledge, recollection, etc. perceptible only where organic body is, are properties of an organized frame, not appartaining to exterior substances, or earth and other elements simple or aggregate, unless formed into such a frame.

While there is body, there is thought, and sense of pleasure and pain, none when body is not, and hence, as well as from selfconsciousness it is concluded that self and body are identical. (H. T. Colebroke, Miscellaneous Essays, vol. II, p. 428 seq.)

The dictum that everyone is the child of his time applies to Wang Ch'ung also, free-thinker though he be. He has thrown over board a great many popular beliefs and superstitions, but he could not get rid of all, and keeps a good deal. His veneration of antiquity and the sages of old is not unlimited, but it exists and induces him to accept many of their ideas, which his 


\section{A. Forke, Introduction and Appendixes to Wang Ch'ung's \\ Lun-hêng}

unbiassed critical genius would probably have rejected. Like the majority p1.025 of his countrymen he believes in Fate and Predestination. However, his Fate is not Providence, for he does not recognise any Superior Being governing the world, and it has been considerably materialised. On a rather vague utterance of Tse Hsia, a disciple of Confucius, who probably never thought of the interpretation it would receive at the hands of Wang Ch'ung, he builds his theory :

« Life and death depend on Destiny, wealth and honour come from Heaven (Analects XII, 5).

The destiny, says Wang Ch'ung, which fixes the duration of human life, is the heavenly fluid, $i$. e. the vital force, with which man is imbued at his birth. This fluid forms his constitution. It can be exuberant, then the constitution is strong, and life lasts long ; or it is scanty, then the body becomes delicate, and death ensues early. This kind of Fate is after all nothing else than the bodily constitution (pp. 1.138 and 1.046). In a like manner is wealth and honour, prosperity and unhappiness transmitted in the stary fluid, with which men are likewise filled at their birth.

« Just as Heaven emits its fluid, the stars send forth their effluence, winch keeps amidst the heavenly fluid. Imbibing this fluid men are born, and live, as long as they keep it. If they obtain a fine one, they become men of rank, if a common one, common people. Their position may be higher or lower, and their wealth bigger or smaller (p. 1.138).

Consequently this sort of Fate determining the amount of happiness which falls to man's share during his life-time, depends on the star or the stars under which he has been born, and can be calculated by the astrologers. This science was flourishing at Wang Ch'ung's time and officially recognised. On all important occasions the court astrologers were consulted.

Now, Fate, whether it be the result of the vital force or of the stary fluid, is not always definitive. It may be altered or modified by various circumstances, and only remains unchanged, if it be stronger than all antagonistic forces. As a rule 
A. Forke, Introduction and Appendixes to Wang Ch'ung's

\section{Lun-hêng}

« the destiny regulating man's life-time is more powerful, than the one presiding over his prosperity (p. 1.137).

If a man dies suddenly, it is of no use that the stary fluid had still much happiness in store for him. Moreover

« the destiny of a State is stronger than that of individuals (Ioc. cit.).

Many persons are involved in the disaster of their country, who by Heaven were predetermined for a long and prosperous life.

The circumstances modifying man's original fate are often denoted as Time. Besides Wang Ch'ung distinguishes Contingencies, Chances, and Incidents, different names for almost the same idea (p. 1.142). These incidents may be happy or unhappy, they may p1.026 tally with the original destiny or disagree with it, completely change it, or be repulsed. If an innocent man be thrown into jail, but is released again, this unlucky contingency was powerless against his favourable destiny; whereas, when hundreds or thousands perish together in a catastrophe

« the disaster they met with was so paramount that their good fate and thriving luck could not ward it off (eod.).

We see Wang Ch'ung's Fate is not the inexorable decree of Heaven, the

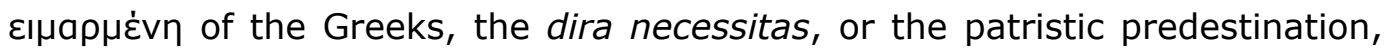
being partly natural (vital fluid), partly supernatural (stary fluid), and partly chance.

Epicurus impugns fatalism, and so does Mê $\mathrm{Ti}$ and his school on the ground that fatalism paralyzes human activity and is subvertive of morality. There were scholars at Wang Ch'ung's time who attempted to mitigate the rigid fatalism by a compromise with self-determination. They distinguished three kinds of destiny: the natural, the concomitant, and the adverse. Natural destiny is a destiny not interfered with by human activity. The concomitant destiny is a combination of destiny and activity both working in the same direction, either for the good or for the bad of the individual, whereas in the adverse destiny the two forces work in opposite directions, but destiny gets the upper hand (p. 1.138). 


\section{A. Forke, Introduction and Appendixes to Wang Ch'ung's \\ Lun-hêng}

Wang Ch'ung repudiates this scholastic distinction, urging that virtue and wisdom, in short that human activity has no influence whatever on fate, a blind force set already in motion before the newborn begins to act (p. 1.141). There is no connection and no harmony between human actions and fate. Happiness is not a reward for virtue, or unhappiness a punishment for crimes. Wang Ch'ung adduces abundance of instances to show, how often the wise and the virtuous are miserable and tormented, while scoundrels thrive and flourish (Chap. XII). Therefore a wise man should lead a tranquil and quiet life, placidly awaiting his fate, and enduring what cannot be changed ( $p$. 1.145).

In the matter of Fate Wang Ch'ung shares all the common prejudices of his countrymen. Fate, he thinks, can be ascertained by astrology and it can be foreseen from physiognomies, omens, dreams, and apparitions of ghosts and spirits. There are special soi-disant sciences for all these branches: anthroposcopy, divination, oneiromancy, necromancy, etc.

Anthroposcopy pretends to know the fate not only from man's features and the lines of his skin (p. 1.047), but also from the osseous structure of the body and particularly from bodily abnormities p1.027 (Chap. XXIV). Many such instances have been recorded in ancient Chinese books. Of features the physiognomists used to distinguish 70 different classes (p. 1.072). In accordance with this theory Wang Ch'ung opines that the vital fluid, the bearer of destiny, finds expression in the forms and features of the body, and can be read by the soothsayers. He remarks that a person's character may likewise be determined from his features, but that no regular science for this purpose has been developed (Chap. XXIV).

Of Omens or Portents there are auspicious and inauspicious ones, lucky or unlucky auguries. Freaks of nature, and rare specimens, sometimes only existing in imagination, are considered auspicious e. $g$. sweet dew and wine springs believed to appear in very propitious times, in the vegetable kingdom : the purple boletus, and auspicious grass, in the animal kingdom : the phœnix, the unicorn, the dragon, the tortoise, and other fabulous animals (p. 1.056). Wang Ch'ung discourses at great length on the nature and the form of these auguries. They are believed to be forebodings of the rise of a 


\section{A. Forke, Introduction and Appendixes to Wang Ch'ung's \\ Lun-hêng}

wise emperor or of the birth of a sage, and harbingers of a time of universal peace. Those Sages are oftentimes distinguishable by a halo or an aureole above their heads. The Chinese historical works are full of such wonderful signs. But all these omens are by no means intentionally sent by Heaven, nor responses to questions addressed to it by man. They happen spontaneously and by chance (p. 1.186), simultaneously with those lucky events, which they are believed to indicate. There exists, as it were, a certain natural harmony between human life and the forces of nature, manifested by those omens.

«Dreams, says Wang Ch'ung, are visions. When good or bad luck are impending, the mind shapes these visions (p. 1.215).

He also declares that dreams are produced by the vital spirit (p. 1.200), which amounts to the same, for the mind is the vital fluid. In Wang Ch'ung's time there already existed the theory still held at present by many Chinese that during a dream the vital spirit leaves the body, and communicates with the outer world, and that it is not before the awakening that it returns into the spiritless body. Wang Ch'ung combats this view, showing that dreams are images only, which have no reality. He further observes that there are direct: and indirect dreams. The former directly show a future event, the latter are symbolical, and must be explained by the oneirocritics.

Wang Ch'ung denies the immortality of the soul, but at the same time he believes in Ghosts and Spirits. His ghosts, however, p1.028 are very poor figures, phantoms and semblances still less substantial than the Shades of Hades. They are unembodied apparitions, have no consciousness (p. 1.194), feel neither joy nor pain, and can cause neither good nor evil (Chap. XLII). They have human shape or are like mist and smoke (Chap. XLIV). The origin of ghosts and spirits is the same as that of the other manifestations of fate : features, omens, and dreams, namely the solar fluid and the vital force or Yang.

«When the solar fluid is powerful, but devoid of the Yin, it can merely produce a semblance, but no body. Being nothing but the vital fluid without bones or flesh, it is vague and diffuse, and when it appears, it is soon extinguished again (Chap. XVIII).

Consequently ghosts and spirits possess the attributes of the solar fluid : 


\section{A. Forke, Introduction and Appendixes to Wang Ch'ung's \\ Lun-hêng}

«The fluid of fire flickers up and down, and so phantoms are at one time visible, and another, not. A dragon is an animal resorting from the Yang principle, therefore it can always change. A ghost is the Yang fluid, therefore it now appears and then absconds. The Yang fluid is red, hence the ghosts seen by people, have all uniform crimson colour. Flying demons are Yang, which is fire. Consequently flying demons shine like fire. Fire is hot and burning, hence the branches and leaves of trees, on which these demons alight, wither and die (eod.).

The solar fluid is sometimes poisonous, therefore a ghost being burning poison, may eventually kill somebody (Chap. XXIII).

Many other theories on ghosts were current at Wang Ch'ung's time, one of which very well agrees with his system, to wit that in many cases ghosts are visions or hallucinations of sick people. Others were of opinion that ghosts are apparitions of the fluid of sickness, some held that they are the essence of old creatures. Another idea was that ghosts originally live in men, and at their deaths are transformed, or that they are spiritual beings not much different from man. According to one theory they would be the spirits of cyclical signs (Chap. XVIII).

According to Wang Ch'ung's idea ghosts and spirits are only one class of the many wonders and miracles happening between heaven and earth.

«Between heaven and earth, he says, there are many wonders in words, in sound, and in writing. Either the miraculous fluid assumes a human shape, or a man has it in himself, and performs the miracles. The ghosts, which appear, are all apparitions in human shape. Men doing wonders with the fluid in them, are sorcerers. Real sorcerers have no basis for what they say, and yet their lucky or unlucky prophecies fall from their lips spontaneously like the quaint sayings of boys. The mouth of boys p1.029 utters those quaint sayings spontaneously, and the idea of their oration comes to wizards spontaneously. The mouth speaks of itself, and the idea comes of itself. Thus the assumption of human form by the miracles, and their sounds are spontaneous, and their words 


\section{A. Forke, Introduction and Appendixes to Wang Ch'ung's \\ Lun-hêng}

come forth of their own accord. It is the same thing in both cases (loc. cit.).

The miraculous fluid may also assume the shape of an animal like the big hog foreboding the death of Duke Hsiang of Ch'i (eod.), or of an inanimate thing like the yellow stone into which Chang Liang was transformed (Chap. XXX).

b) Physics

Wang Ch'ung does not discriminate between a transcendental Heaven and a material Sky. He knows but one solid Heaven formed of the Yang fluid and filled with air.

This Heaven appears to us like an upturned bowl or a reclining umbrella, but that, says Wang Ch'ung, is an of optical illusion caused by the distance. Heaven and Earth seem to be joined at the horizon, but experience shows us that that is not the case. Wang Ch'ung holds that Heaven is as level as Earth, forming a flat plain (Chap. XX).

Heaven turns from East to West round the Polar Star as a centre, carrying with it the Sun, the Moon, and the Stars. The Sun and the Moon have their own movements in opposite direction, from West to East, but they are so much slower than that of Heaven, that it carries them along all the same. He compares their movements to those of ants crawling on a rolling mill-stone (eod.). Plato makes Heaven rotate like a spindle. The planets take part in this movement of Heaven, but at the same time, though more slowly, move in

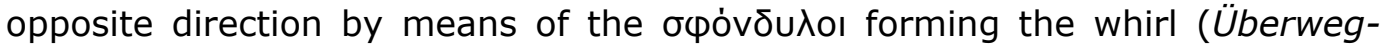
Heinze, Geschichte der Philosophie, vol. I, p. 180).

Heaven makes in one day and one night one complete circumvolution of 365 degrees. One degree being calculated at 2,000 Li, the distance made by Heaven every 24 hours measures $730,000 \mathrm{Li}$. The sun proceeds only one degree $=2,000 \mathrm{Li}$, the Moon 13 degrees 26,000 Li. Wang Ch'ung states that this is the opinion of the Literati (eod.). Heaven's movement appears to us very slow, owing to its great distance from Earth. In reality it is very fast. The Chinese mathematicians have computed the distance at upwards of 60,000 Li. The Taoist philosopher Huai Nan Tse avers that it measures 50,000 Li (Chap. 


\section{A. Forke, Introduction and Appendixes to Wang Ch'ung's \\ Lun-hêng}

XIX).

p1.030 The body of the Earth is still more solid than that of Heaven and produced by the Yin fluid. Whereas Heaven is in constant motion, the Earth does not move (Chap. XX). It measures 10,000 million square Li, which would be more than 2,500 million square-km., and has the shape of a rectangular, equilateral square, which is of course level. Wang Ch'ung arrives at these figures in the following way. The city of Loyang in Honan is by the Chinese regarded as the centre of the world and Annam or Jih-nan as the country over which the sun in his course reaches the southermost point. Annam therefore would also be the southern limit of the Earth. The distance between Loyang and Annam is 10,000 Li. Now, Chinese who have been in Annam have reported that the sun does not reach his south-point there, and that it must be still further south. Wang Ch'ung assumes that it might be 10,000 Li more south. Now Loyang, though being the centre of the known world i. e. China, is not the centre of the Earth. The centre of the Earth must be beneath the Polar Star, the centre of Heaven. Wang Ch'ung supposes the distance between Loyang and the centre of the Earth below the pole to be about 30,000 Li. The distance from the centre of the Earth to its southern limit, the south-point of the sun, thus measuring about $50,000 \mathrm{Li}$, the distance from the centre to the north-point must be the same. That would give $100,000 \mathrm{Li}$ as the length of the Earth from north to south, and the same number can be assumed for the distance from east to west (Chap. XIX).

The actual world (China) lies in the south-east of the universe (Chap. XX). This peculiar idea may owe its origin to the observation that China lies south of the Polar Star, the centre of Heaven, and that at the east-side China is bordered by the ocean, whereas in the west the mainland continues.

Tsou Yen, a scholar of the 4th cent. B. C. has propounded the doctrine that there are Nine Continents, all surrounded by minor seas, and that China is but one of them, situated in the south-east. Beyond the Nine Continents there is still the Great Ocean. Wang Ch'ung discredits this view, because neither the Great $Y \ddot{u}$, who is believed to have penetrated to the farthest limits of the Earth and to have written down his observations in the Shan-hai-king, nor Huai Nan Tse, who had great scholars and experts in his service, mention 


\section{A. Forke, Introduction and Appendixes to Wang Ch'ung's \\ Lun-hêng}

anything about different continents (Chap. XIX).

This Earth is high in the North-West and low in the South-East, consequently the rivers flow eastwards into the ocean (Chap. XX). This remark again applies only to China, which from the table land of Central Asia slopes down to the ocean, where all her big rivers flow.

p1.031 Among the celestial bodies the Sun is the most important. He is a star like the Moon and the Planets, consisting of fire. His diameter has been found to measure $1,000 \mathrm{Li}$. The Sun follows the movement of Heaven, but has his own at the same time. The common opinion that the sun and the other stars are round is erroneous. They only appear so by the distance. The Sun is fire, but fire is not round. The meteors that have been found, were not round. Meteors are stars, ergo the stars are not round (loc. cit.).

At noon, when the Sun is in the zenith, he is nearer to us than in the morning or the evening, because the perpendicular line from the zenith to the earth is shorter than the oblique lines, which must be drawn at sunrise or sunset. It is for this reason also that the sun is hottest, when is culminating. That the Sun in the zenith appears smaller than, when he rises or sets, whereas, being nearer then, he ought to be bigger, is because in bright daylight every fire appears smaller than in the darkness or at dawn (eod.).

This question has already been broached by Lieh Tse V, 9 who introduces two lads disputing about it, the one saying that the Sun must be nearer at sunrise, because he is larger then, the other retorting that at noon he is hottest, and therefore must be nearest at noon. Confucius is called upon to solve the problem, but cannot find a solution.

Wang Ch'ung is much nearer the truth than Epicurus, whose notorious argument on the size of the sun and the moon, is not very much to his credit. He pretends that the stars must be about the size, which they appear to us, because fires did not lose anything of their heat, or their size by the distance (Diog. Laert. X, 91), which is an evident mis-statement. Lucretius repeats these arguments (Lucr. V, 554-582).

The different lengths of day and night in winter and summer Wang Ch'ung attributes to the shorter and longer curves described by the Sun on different 


\section{A. Forke, Introduction and Appendixes to Wang Ch'ung's \\ Lun-hêng}

days. In his opinion the Sun would take 16 different courses in heaven during the year. Other scholars speak of 9 only (eod.). Wang Ch'ung is well acquainted with the winter and summer Solstices and the vernal and autumnal Equinoxes (eod.).

Whereas the Sun consists of fire, the Moon is water. Her apparent roundness is an illusion; water has no definite shape (eod.). Of the movement of the Moon we have already spoken. In Chinese natural philosophy the Moon is always looked upon as $\mathrm{p} 1.032_{2}$ the opposite of the Sun. The Sun being the orb of day and light is Yang, fire, consequently the Moon, the companion of night and darkness, must be Yin, water. The Sun appears brilliant and hot like a burning fire, the Moon pale and cool like glistening water. What wonder that the ancient Chinese should have taken her for real water, for Wang Ch'ung merely echoes the general belief.

In the matter of Eclipses Wang Ch'ung does not fall in with the view of many of his time, to the effect that the Sun and the Moon over-shadow and cover one another, nor with another theory explaining the eclipses by the preponderance of either of the two fluids, the Yin or the Yang, but holds that by a spontaneous movement of their fluids the Sun or the Moon shrink for a while to expand again, when the eclipse is over. He notes that those eclipses are natural and regular phenomena, and that on an average an eclipse of the Sun occurs every 41 or 42 months, and an eclipse of the Moon every 180 days (eod.).

Epicurus and Lucretius are both of opinion that the fading of the Moon may be accounted for in different ways, and that there would be a possibility that the Moon really decreases i. e. shrinks together, and then increases again (Diog. Laert. X, 95 ; Lucr. V, 719-724).

Wang Ch'ung is aware that $e b b$ and high-tide are caused by the phases of the Moon, and that the famous 'Bore' at Hangchou is not an ebullition of the River, resenting the crime committed on Wu Tse Hsü, who was unjustly drowned in its waters (p. 1.048).

The Stars except the Five Planets, which have their proper movement, are fixed to Heaven, and turn round with it. Their diameter has been estimated at about $100 \mathrm{Li}$ viz. $1 / 10$ of the diameter of the Sun. That they do not appear 


\section{A. Forke, Introduction and Appendixes to Wang Ch'ung's \\ Lun-hêng}

bigger to us than eggs is the effect of their great distance (Chap. XX). They are made of the same substances as the Sun and the Moon and the various things, and not of stone like the meteors. They emit a strong light. The Five Planets : Venus, Jupiter, Mercury, Mars, and Saturn consist of the essence of the Five Elements : water, fire, wood, metal, and earth. The fact that the Five planets are in Chinese named after the Five Elements: The Water Star (Mercury), the Fire Star (Mars), etc. must have led Wang Ch'ung to the belief that they are actually formed of these elements. The language must also be held responsible for another error into which Wang Ch'ung has fallen. He seems to believe that the stars and constellations are really what their Chinese names express e. g., that there are hundreds of officials and two famous charioteers in 1.033 Heaven, who by emitting their fluid, shape the fate of men, (p. 1.138) and that the 28 Solar Mansions are actually celestial postal stations (Chap. XIX). It is possible however that the intimations of Wang Ch'ung to this effect are not to be taken literally, and that he only makes use of the usual terminology without attaching to them the meaning which his words would seem to imply. We are sometimes at a loss to know, whether Wang Ch'ung speaks his mind or not, for his words are often only rhetorical and dialectical devices to meet the objections of his opponents.

Wang Ch'ung's ideas on Meteors and Shooting Stars are chiefly derived from some classical texts. He comes to the conclusion that such falling stars are not real stars, nor stones, but rain-like phenomena resembling the falling of stars (Chap. XX).

Rain is not produced by Heaven, and, properly speaking, does not fall down from it. It is the moisture of earth, which rises as mist and clouds, and then falls down again. The clouds and the fog condense, and in summer become Rain and Dew, in winter Snow and Frost (eod.). There are some signs showing that it is going to rain. Some insects become excited. Crickets and ants leave their abodes, and earth-worms come forth. The chords of guitars become loose, and chronic diseases more virulent. The fluid of rain has this effect (p. 1.109).

The same holds good for Wind. Birds foresee a coming storm, and, when it is going to blow, become agitated. But Wang Ch'ung goes farther and 


\section{A. Forke, Introduction and Appendixes to Wang Ch'ung's \\ Lun-hêng}

adopts the extravagant view that wind has a strange influence on perverted minds, such as robbers and thieves, prompting them to do their deeds, and that by its direction it influences the market-prices. From its direction moreover, all sorts of calamities can be foreseen such as droughts, inundations, epidemics, and war (p. 1.111). There is a special science for it, still practised to-day by the Imperial Observatory at Peking.

Heat and Cold correspond to fire and water, to the regions, and to the seasons. Near the fire it is hot, near the water, cool. The Yang fluid is the source of heat, the Yin fluid that of cold. The South is the seat of the Yang, the North of the Yin. In summer the Yang fluid predominates, in winter the Yin. The temperature can never be changed for man's sake, nor does Heaven express its feelings by it. When it is cold, Heaven is not cool, nor is it genial and cheerful, when it is warm (Chap. XXI).

When the Yin and the Yang fluids come into collision, we have Thunder and Lightning (p. 1.126). The fire of the sun colliding with the water of the clouds causes an explosion, which is the p1.034 thunder. Lightning is the shooting forth of the exploding air (Chap. XXII, XXIX). Wang Ch'ung alleges 5 arguments to prove that lightning must be fire (Chap. XXII). He ridicules the idea that thunder is Heaven's angry voice, and that with its thunderbolt it destroys the guilty.

«When lightning strikes, he says, it hits a tree, damages a house, and perhaps kills a man. But not unfrequently a thunder-clap is without effect, causing no damage, and destroying no human life. Does Heaven in such a case indulge in useless anger?

And why did it not strike a fiend like the Empress Lü Hou, but often kills sheep and other innocent animals ? (eod.) Lucretius asks the same question :

«Quod si Juppiter atque alii fulgentia divi terrifico quatiunt sonitu cælestia templa et jaciunt ignem quo qoiquest cumque voluptas, cur quibus incautum scelus aversabile cumquest non faciunt icti flammas ut fulguris halent pectore perfixo, documen mortalibus acre, et potius nulla sibi turpi conscius in re 


\section{A. Forke, Introduction and Appendixes to Wang Ch'ung's \\ Lun-hêng}

volvitur in flammis innoxius inque peditur

turbine cælesti subito correptus et igni ?

cur etiam loca sola petunt frustraque laborant ?

(Lucr. VI, 380-389).

The poet states that tempests are brought about by the conflict of the cold air of winter with the hot air of summer. It is a battle of fire on the one, and of wind and moisture on the other side. Lightning is fire (eod. 355-375). Thunder is produced by the concussion of the clouds chased by the wind (eod. 94 seq.).

c) Ethics

In the Lun-hêng, ethical problems take up but a small space. Probably Wang Ch'ung has treated them more in detail in his lost work, the Chi-suchieh-yi 'Censures on Morals'. In the Lun-hêng they are touched upon more incidentally.

Men are all endowed with the same heavenly fluid, which becomes their vital force and their mind. There is no fundamental difference in their organisation. But the quantity of the fluids varies, whence the difference of their characters.

«The fluid men are endowed with, says Wang Ch'ung, is either copious or deficient, and their characters correspondingly good or bad (Chap. XXXI).

Epicurus explains the difference of human characters by the different mixture of the four substances coustituting the soul.

p1.035 The vital fluid embraces the Five Elements of Chinese natural philosophy : Water, fire, wood, metal, and earth, which form the Five Organs of the body : the heart, the liver, the stomach, the lungs, and the kidneys. These inner parts are the seats of the Five Virtues: benevolence, justice, propriety, knowledge, and truth (p. 1.105). The Five Virtues are regarded as the elements of human character and intelligence. Thus the quantity of the original fluid has a direct influence upon the character of the person. A small dose produces but a small heart, a small liver, etc. and these organs being 


\section{A. Forke, Introduction and Appendixes to Wang Ch'ung's \\ Lun-hêng}

small the moral and mental qualities of the owner can be but small, insufficient, bad. The copiousness of the fluid has the opposite result.

The Five Organs are the substrata of the 'Five Virtues'. Any injury of the former affects the latter. When those organs become diseased, the intellect loses its brightness, and morality declines, and, when these substrata of the mind and its virtues are completely destroyed by death, the mind ceases likewise (p. 1.195).

Being virtually contained in the vital or heavenly fluid, the Five Virtues must come from Heaven and be heavenly virtues (Chap. XLIII). Heaven is unconscious and inactive, therefore it cannot practise virtue in a human way, but the results of the spontaneous movement of the heavenly fluid are in accordance with virtue. It would not be difficult to qualify the working of nature as benevolent, just, and proper, which has been done by all religions, although unconscious benevolence and unconscious justice are queer notions, but how about unconscious knowledge and unconscious truth, the last of the Five Virtues? Wang Ch'ung finds a way out of this impasse :

«The heart of high Heaven, he says, is in the bosom of the Sages, an idea expressed already in the Liki (Cf. Legge's transl. Vol. I, p. 382). Heaven feels and thinks with their hearts (p. 1.128 seq.). Heaven has no heart of its own, but the heart of the Sages as well as of men in general are its hearts, for they have been produced by the heavenly fluid. This fluid, originally a shapeless and diffuse mass, cannot think or feel by itself. To become conscious it requires an organism. In so far it can be said that by consulting one's own heart, one learns to know the will of Heaven, that

« Heaven acts through man

and that

«when it reprimands, it is done through the mouths of Sages (eod.).

Wang Ch'ung does not enter upon a discussion on what the moral law really is, and why it is binding. He simply takes the Five Virtues in the acceptation given them by the Confucianists. But he ventilates another question, which has been taken up by 1.036 almost all the moralists from 


\section{A. Forke, Introduction and Appendixes to Wang Ch'ung's \\ Lun-hêng}

Mencius downward, that of the original goodness or badness of human nature. Wang Ch'ung acquaints us with the different views on this subject. The two extremes are represented by Mencius, who advocates the original goodness, and by Hsün Tse, who insists upon its badness. There are many compromises between these two contrasting theories. Wang Ch'ung himself takes a middle course, declaring that human natural disposition is sometimes good, and sometimes bad, just as some people are by nature very intelligent, while others are feeble-minded (Chap. XXXII).

Original nature may be changed by external influences. Good people may become bad, and bad ones may reform and turn good. Such results can be brought about by intercourse with good or bad persons. With a view to reforming the wicked the State makes use of public instruction and criminal law (Chap. XXXI). Wang Ch'ung adopts the classification of Confucius, who distinguishes average people and such above and below the average (Analects VI, 19).

« The character of average people, he says, is the work of habit. Made familiar with good, they turn out good, accustomed to evil, they become wicked. Only with extremely good, or extremely bad characters habit is of no avail.

These are the people above and below the average. Their characters are so inveterate, that laws and instructions are powerless against them. They remain what they are, good or bad (Chap. XXXII).

The cultivation of virtue is better than the adoration of spirits, who cannot help us (Chap. XLIV). Yet it would be a mistake to believe that virtue procures happiness. Felicity and misfortune depend on fate and chance, and cannot be attracted by virtue or crime (Chap. XXXVIII). On the whole Wang Ch'ung does not think much of virtue and wisdom at all. He has amalgamated the Confucian Ethics with his system as far as possible, but the Taoist ideas suit him much better and break through here and there. The Taoists urge that virtue and wisdom are a decline from man's original goodness. Originally people lived in a state of quietude and happy ignorance. 


\section{A. Forke, Introduction and Appendixes to Wang Ch'ung's \\ Lun-hêng}

«Virtuous actions were out of the question, and the people were dull and beclouded. Knowledge and wisdom did not yet make their appearance (p. 1.100).

They followed their natural propensities, acted spontaneously, and were happy. Such was the conduct of the model emperors of antiquity, Huang Ti, Yao, and Shun. They lived in a state of quietude and indifference, did not work, and the empire was governed by itself (p. 1.098). They merely imitated Heaven, who's principle is spontaneity and p1.037 inaction. Now-a-days this high standard can only be attained by the wisest and best men.

«A man with the highest, purest, and fullest virtue has been endowed with a large quantity of the heavenly fluid, therefore he can follow the example of Heaven, and be spontaneous and inactive like it (loc. cit.).

He need not trouble about virtue, or act on purpose, for he is naturally virtuous, and all his spontaneous deeds are excellent. The majority of people, however, cannot reach this height. Having received but a small quota of the heavenly fluid, they cannot follow its example, and become active. They practise the routine virtues, which for the superior man, who naturally agrees with them, are of little importance.

\section{d) Critique}

Wang Ch'ung not only criticises the common ideas, superstitions, and more or less scientific theories current at his time, but he also gives his judgment upon the principal scholars, whose tenets he either adopts or controverts, and it is not without interest to learn, how he values well known philosophers and historians.

\section{a. Philosophers}

Of all philosophers by far the most frequently cited is Confucius. In Wang Ch'ung's estimation he is the Sage of China. He calls him the

«Nestor in wisdom and virtue, and the most eminent of all philosophers (Chap. XXXII). 


\section{A. Forke, Introduction and Appendixes to Wang Ch'ung's}

\section{Lun-hêng}

Wang Ch'ung seems to believe that he has won his cause, whenever he can quote Confucius as his authority, and that with a dictum of the Sage he can confound all his adversaries. In quoting Confucius he uses great liberty, interpreting his utterances so as to tally with his own views. But this veneration does not prevent him from criticising even Confucius. He thinks it necessary to vindicate himself from the charge of impiety and immorality, intimating that even Sages and Worthies are not infallible and may err sometimes (Chap. XXXIII). He might have done anything else, but this offence the Literati will never condone. His attacks on Confucius are very harmless and not even very clever. He does not impugn the Confucian system, which on the contrary he upholds, though he departs from it much farther than he himself knows. His method consists in hunting up contradictions and repugnancies in the Analects. He not seldom constructs a contradiction, where there is none at all, by putting much more into the

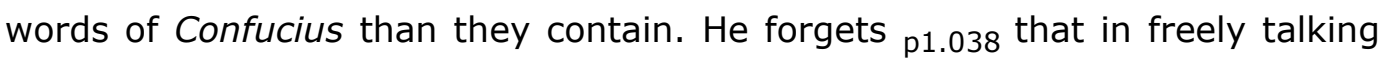
with friends or pupils - and the Analects are nothing else than such conversations - one does not weigh every word. Besides the peculiar circumstances and the form of mind of the speaker must be taken into consideration, which Wang Ch'ung often neglects. In short, the essay on Confucius is in no way a master-piece of criticism and not worth the fuss made about it.

Mencius, the second Sage, is also very often mentioned. Wang Ch'ung holds him in high esteem, but treats his work in the same way as the Analects. The objections raised keep more or less on the surface, and do not affect the substance of his doctrine.

The highest praise is bestowed on Yang Hsiung, another famous Confucianist of the Han epoch. Wang Ch'ung compares the historian Sse Ma Ch'ien with the Yellow River and Yang Hsiung with the Han (Chap. XXXVII). He rose like a star (p. 1.081), and his chief work, the Tai-Hsüan-ching was a creation (p. 1.088).

Like Huai Nan Tse, Wang Ch'ung very often mentions Mê Ti conjointly with Confucius as the two great Sages of antiquity. At that time the fame of Confucius had not yet eclipsed the philosopher of mutual love. Though 


\section{A. Forke, Introduction and Appendixes to Wang Ch'ung's \\ Lun-hêng}

appreciating him, Wang Ch'ung rejects his system as unpractical, maintaining that its many contradictions have prevented its spreading (Chap. XXXVII). The Mêhists believe in ghosts and spirits and adore them, imploring their help. At the same time they neglect the funerals and the dead, and they deny the existence of fate.

When Lao Tse is referred to, he is usually introduced together with Huang Ti, who like Lao Tse is looked upon as the father of Taoism. They are both called truly wise (p. 1.098). The Taoist school established the principle of spontaneity and inaction. The philosophy of Wang Ch'ung is to a great extent based on their doctrines without, however, becoming Taoistic, for he leaves out the quintessence of their system, Tao, nor will he have anything of their transcendentalism, mysticism or other extravagancies.

Wang Ch'ung is well acquainted with the Taoist writer Huai Nan Tse, from whose work he freely culls, oftener than he mentions him. He refutes the legend that Huai Nan Tse by his alchimistical studies obtained immortality, and with his entire household, including his dogs and poultry ascended to Heaven, submitting that he either was beheaded for some political intrigues or committed suicide (Chap. XXVIII).

Against Han Fei Tse, who wrote on the theory of government and legislation, and whose writings are strongly tainted with Taoism, Wang Ch'ung shows a pronounced antipathy. He most p1.039 vehemently attacks him for having declared the scholars and literati to be useless grubs in the State. Han Fei Tse was of opinion that rewards and punishments were sufficient to keep up order. Wang Ch'ung objects that in his system virtue has no place. Han Fei Tse despises divination, which Wang Ch'ung defends. Han Fei Tse was much appreciated by the Emperor Ch'in Shih Huang Ti, a great admirer of his works, which, however, did not hinder the tyrant from condemning him to death for some political reason.

It is passing strange that the great Taoist philosophers Lieh Tse and Ch'uang Tse are not once named. Were they so little read at Wang Ch'ung's time, that he did not know them ? Some of his stories are told in Lieh Tse likewise with nearly the same words, but it does not follow, that they must be quoted from Lieh Tse, for such narrations are often found in several authors, 


\section{A. Forke, Introduction and Appendixes to Wang Ch'ung's}

\section{Lun-hêng}

one copying from the other without acknowledging his source.

A scholar, of whom Wang Ch'ung speaks very often is Tung Chung Shu, a very prolific writer of the 2 nd cent. B. C. He was said by many to have completed the doctrine of Confucius, while others held that he had perverted it. Wang Ch'ung thinks that both views are wrong (Chap. XXXVII). Tung Chung Shu devoted his labours to the Ch'un-ch'iu, but he also wrote on the magical arts (p. 1.084) and on Taoism. Wang Ch'ung says that his arguments on Taoist doctrines are very queer, but that his ideas on morals and on government are excellent. In human nature Tung Chung Shu distinguishes between natural disposition and feeling. The former, he says, is the outcome of the Yang principle and therefore good, the feelings are produced by the Yin and are therefore bad (Chap. XXXII).

Tung Chung Shu seems to have been the inventor of a special rainsacrifice. The figure of a dragon was put up to attract the rain. Wang Ch'ung stands up for it with great fervour and attempts to prove its efficacy ( $p$. 1.055, N. 47).

Of Tsou Yen many miracles were already related at Wang Ch'ung's time. He rejects them as fictions. Tsou Yen's writings were brilliant, he says, but too vague and diffuse (Chap. XXXVII). With his above mentioned theory of the Nine Continents Wang Ch'ung does not agree.

The sophist Kung Sun Lung as well as Kuan Tse and Shang Yang, who both have philosophised on the State, are rather severely dealt with (Chap. XXXVII). On the other hand Wang Ch'ung a very lavish in his praise of the writers of the Han time viz. Liu Hsiang, Lu Chia, author of the Hsin-yü, a work on government, Huan Chün Shan, author of the Hsin-lun, and Huan K'uan, who wrote the p1.040 Yen-t'ieh-lun, a work on finance and other State questions. Besides Wang Ch'ung gives the names of a number of his contemporaries to whom he predicts immortality, but he has been a bad prophet, for save one they are all forgotten now.

\section{ß. Historians.}

It was a great controversy during the Han epoch, which commentary to the Ch'un-ch'iu was the best. The Tso-chuan had not yet secured the position, 
A. Forke, Introduction and Appendixes to Wang Ch'ung's

\section{Lun-hêng}

it holds now ; many scholars gave the preference to the works of Kung Yang or Ku Liang. Wang Ch'ung avers that Tso Ch'iu Ming's Tso-chuan surpasses all the others, and that having lived nearer to Confucius' time than the other commentators, Tso Ch'iu Ming has had more facilities to ascertain the views of the Sage and to give them in their purest form. Wang Ch'ung confirms that the Kuo-yü is also the work of Tso Ch'iu Ming (Chap. XXXVII). Many of Wang Ch'ung's stories and myths are taken from the Tso-chuan.

Of the Lü-shih-ch'un-ch'iu of Lü Pu Wei, an important work for antique lore, Wang Ch'ung says that it contains too much of the marvellous.

To illustrate his theories Wang Ch'ung often lays the Shi-chi under contribution. Of its author, Sse Ma Ch'ien, he speaks with great deference, and regards him as the greatest writer of the Han period. What he reproaches him with, is that Sse Ma Ch'ien too often leaves us in the dark as to his own opinion on a question, stating only the bare facts, or giving two different versions of the same event without deciding, which is the correct one (Ioc. cit.).

Pan Ku, Wang Ch'ung's contemporary and the son of his teacher Pan Piao, is lauded for his good verses and memorials (loc. cit.). He is the one contemporary of our philosopher, who really has become immortal by his great work, the Han-shu. At Wang Ch'ung's time it had not yet appeared, and so is never referred to. It was completed and published after Pan Ku's death by his sister Pan Chao.

That he possesses some abilities in the field of literary and historical critique himself, Wang Ch'ung shows in his remarks on the origin and history of the Classics. He tells us, how they were composed, how discovered after the Burning of the Books, how handed down, and how divided into books and chapters (Chap. XXXVI). In spite of his profound veneration for the classical literature he does not hesitate to censure those passages, which do not find his approval, or to expose the exaggerations and fables $\mathrm{p} 1.041_{1}$ with which they teem (p. 1.051, N. 27). In like manner he is indefatigable in detecting Taoist fictions and inventions and in reducing them to their true measure, for it does not satisfy him to demonstrate their impossibility ; he desires to find out, how they originated (p. 1.050, N. 24). He combats the legends which have found 


\section{A. Forke, Introduction and Appendixes to Wang Ch'ung's \\ Lun-hêng}

their way into the historical literature, although they are less frequent than in the Taoist works (p. 1.050, N. 25-26). The entire Lun-hêng is a big battle against these errors. His discussions would seem sometimes a little lengthy, and the subject not to require such an amount of arguments, for we would prove the same with a few words, or not discuss it at all, the proposition being for us self-evident. We must however bear in mind, that what for us now is self-evident and indisputable, was not so for the Chinese, for whom Wang Ch'ung wrote his book, and that to shake them in their deep-seated persuasions a huge apparatus of logic was necessary. Even then probably the majority held fast to their preconceptions. The triumphant march of logic is checked, as soon as sentiment and prejudice comes in.

Historically Wang Ch'ung takes another point of view than his contemporaries, who for the most part took little interest in their own time, and let their fancies wander back to the golden age of remote antiquity. Wang Ch'ung is more modern than most Chinese of the present day. He was of opinion that the Han dyuasty was as good, even better than the famous old dynasties (p. 1.056, N. 56). Five essays bear upon this thesis. His reasoning is very lame however, for instead of speaking of the government, he only treats of the auspicious portents proving the excellence of the ruling sovereigns.

e) Religion and Folklore.

The religion of the Chinese at the Han time was a cult of nature combined with ancestor worship. They regarded certain parts of nature and certain natural phenomena as spirits or as animated by spirits, and tried to propitiate them and the ghosts of their ancestors by prayers and sacrifices. Convinced that these spirits and ghosts could help them, or do them harm, as they chose, they contrived to win their good graces, praying for happiness, imploring them to avert evil, and showing their gratitude for received benefits by their offerings.

The chief deities worshipped during the Chou period were :

Heaven and its parts : the Sun, the Moon, and the Stars. Among the latter the Five Planets take the first place, but the 28 Solar Mansions and other 


\section{A. Forke, Introduction and Appendixes to Wang Ch'ung's \\ Lun-hêng}

constellations, such as the Dipper and the Stars of Longevity were likewise adored.

Earth and its parts, Mountains and Rivers, the Soil, and the Grain growing on it, and some of its phenomena : Earth-quakes, Water (Inundations), and Droughts.

Meteorological phenomena : Wind and Rain, Heat and Cold, Thunder and Lightning.

The Four Seasons and the Four Quarters.

The Five Parts of the House: The Gate, the Door, the Wall, the Hearth, and the Court.

Deified Heaven was often looked upon as an emperor, the Emperor on High or the Supreme Ruler, and so were the Planets, called the Blue, Red, Yellow, White, and Black Emperors. The other stars and constellations were their officials. All these deities have, as a rule, no distinct personality, and still quite clearly show the traces of their origin. The 'Prince of the Wind', the 'Master of Rain', the 'Thunderer', the 'Door God', and the 'Spirit of the Hearth' or 'Kitchen God' were perhaps more than the others apprehended as personal gods.

The Spirits of the Soil and Grain were at the outset probably not different from the other spirits animating nature, but according to very old traditions two persons: Kou Lung and Ch'i have after their deaths been deified and raised to the rank of tutelary genii of the land and grain. These apotheoses of men after their death became more frequent in later ages. Under the Ch'in dynasty Ch'ih $Y u$, a legendary personage renownded for his military exploits, was worshipped as War God. The three sons of the mythical emperor Chuan Hsü after their death became Water Spirits and Spirits of Epidemics, and a woman, who had died in childbed, and whose ghost had appeared to somebody after her decease, was made Princess of Demons under the Han dynasty.

Here we have ancestral worship. Every family used to revere the ghosts of its deceased ancestors, but only in such exceptional cases as those quoted above did these ghosts later on become national gods. 


\section{A. Forke, Introduction and Appendixes to Wang Ch'ung's \\ Lun-hêng}

The cult of the afore-mentioned deities was continued during the Han epoch, and with some few alterations has gone on up to the present day. It is the State religion of China, sanctioned by Government, and practised by the Son of Heaven and his highest officials. Buddhism and Taoism are only tolerated. Confucianism p1.043 is no religion, but the official moral system, which completely agrees with the cult of nature.

The sacrifices to the spirits of nature were in ancient times performed by the Emperor, the Feudal Princes, and the officials, acting as high-priests for their people. The people used to sacrifice only to their own ancestors and to the Spirits of the Door or the Hearth. The oblations were burnt-offerings of animals and libations of wine. There was no clergy to mediate between the gods and the people. These rules were less strictly observed during the Han epoch, when occasionally priests sacrificed in the place of the Emperor, and even priestesses were allowed to make offerings in their temples. In out-ofthe-way places, where no officials were near, the people could themselves worship the gods, whose service else was incumbent upon the magistrates (cf. Chap. XLI, XLII and Shi-chi chap. 27-28).

Wang Ch'ung asserts that most of these sacrifices are superfluous, because the deities thus honoured are merely parts of others, to which offerings are made likewise. The Sun, the Moon, and the Stars are parts of Heaven. They must participate in the oblations offered to Heaven, why then give them special sacrifices to boot ? With Mountains and Rivers, the Soil and Grain, which are the constituent parts of Earth, it is the same. Would any reasonable person, irrespective of his usual meals, specially feed his limbs ? (Chap. XLI.)

Moreover, spirits and ghosts cannot enjoy the sacrifices, for there are none, at least not personal beings, as people seem to imagine (Chap. XLIV). If they were air, they could not eat nor smell, and if they had a body, it would be so enormous, that men could never satisfy their appetite. How should they feed the Earth or even a Mountain or a River ? (eod. and Chap. XLI.) Being formed of the shapeless fluid, ghosts and spirits can neither feel nor act, consequently they cannot do anything for man nor against him. Ergo by sacrifices he does not obtain his end, divine protection (Chap. XLII). 


\section{A. Forke, Introduction and Appendixes to Wang Ch'ung's \\ Lun-hêng}

Therefore sacrifices can be nothing more than symbolical acts, showing the gratitude and the affection of the sacrificer. He is thankful for all the kindness he has received from Heaven and Earth, and from his parents and forefathers (eod.). Sacrifices are manifestations of the piety of him, who offers them, but their omission cannot have any evil consequence.

Exorcism is the correlate of prayers and sacrifices. The ancient Chinese used to practise it particularly with the Spirit of Sickness, whom they expelled. Wang Ch'ung thinks it as useless as p1.044 sacrifices, for, says he, provided the spirits are mist and vapours, they cannot do any harm, should they really exist, however, then they would indubitably not allow themselves to be driven off. They would not only offer resistance, but also resent the affront, and take their revenge upon the exorcist (Chap. XLIV).

Primitive Chinese religion has not produced a mythology worth speaking of, but a variety of superstitions have clustered around it. Some of them Wang Ch'ung brings to our notice. The principle aim of Chinese religion is to obtain happiness and to remove evil. But is does not suffice to worship the spirits, one must also avoid such actions, as might bring down misfortune. In the popular belief there is a certain mystic connection, a sort of harmony between fate and human activity, though one does not see how. When the Yamen officials are very bad, the number of tigers increases so much, that plenty of people are devoured by them. The rapacity of the underlings is believed to cause grubs and insects to eat grain (p. 1.055, N. 48-49). It is dangerous to extend a building to the west, one must not see women who recently have given birth to a child, and children born in the first or the fifth months should not be brought up, for they will be the cause of their parents death (p. 1.059, N. 68). Exceptional precautions must be taken in building a new house (p. 1.060, N.74).

For most actions in every-day-life the time chosen is of the utmost importance. An unlucky time spoils everything. The Chinese at the Han epoch had not only their dies fasti and nefasti, but propitious and unpropitious years, months, days, and hours. Special books gave the necessary information. For some actions certain lucky days had to be chosen, for others certain unlucky once had to be avoided. Special days were assigned for the 


\section{A. Forke, Introduction and Appendixes to Wang Ch'ung's \\ Lun-hêng}

commencing of a new-building or for funerals. Bathing on certain days, women were sure to become lovely, on others they would become illfavoured. Moving one's residence one should avoid a collision with the Spirit of the North, T'ai Sui (p. 1.059, N. 70, 72, 73). People neglecting these rules would fall in with malignant spirits, or meet with evil influences. These ideas have come down to our time, and are still cherished by the majority of the Chinese. The calendar published every year by the Board of Astronomy serves them as a guide, noting that which may be safely done on each day, and that which may not. Wang Ch'ung has done his best to eradicate these superstitions, showing their unreasonableness and futility, as we see with little success, so deeply are they still rooted in the Chinese mind after nearly two thousand years. p1.045

\section{Table of Contents of the Lun-hêng ${ }^{1}$}

\section{Book I.}

1. Chap. I. Feng-yü 逢遇 (Success and Luck, II, IV).

This chapter treats of the relation between officers and the sovereign. To be appreciated and successful an official must find the right prince, who understands him and puts him in the right place. One must not make the successful responsible for the success, or the unsuccessful for their failure, because not their talents, but time and circumstances are decisive.

2. Chap. II. Lei-hai 累書 (Annoyances and Vexations, II, V).

The difficulties and annoyances which people have to endure come from abroad, and are not the result of their own works. Therefore they must not be blamed. Fear and good conduct have influence on fortune or misfortune.

1 Pour chaque chapitre, le premier lien renvoie au Lun-hêng en 1 volume (classement original des essais); le deuxième renvoie au Lun-hêng en 2 volumes, (classement Forke). 


\section{A. Forke, Introduction and Appendixes to Wang Ch'ung's \\ Lun-hêng}

« Fortune is what we obtain without any effort of our own, and misfortune what happens to us without our co-operation.

The chief annoyances of officials at the court and in the provinces are slanderous reports of envious persons. Three kinds of calumnies are distinguished. The wise do not feel troubled about this, and lead the life which most suits them.

3. Chap. III. Ming-lu 命瓶 (On Destiny and Fortune, I, IX).

Destiny predetermines the length of man's life, and whether he shall be rich and honourable, or poor and mean. There is no correspondence between human virtue and fate. The wicked and the unintelligent are very often happy, whereas men endowed with the highest faculties and the noblest character perish in misery, as is shown by various examples from history. The knowing, therefore, do not hunt after happiness, but leave everything to Heaven, suffering with equanimity what cannot be avoided, and placidly awaiting their turn. The opinions of several philosophers holding similar views are given.

4. Chap. IV. Ch'i-shou 氣尌 (Long Life and Vital Fluid, I, XXV).

There are two kinds of fate, the one determining the events of life, the other its length. The length of life depends on the p1.046 quantity of the vital fluid received at birth. Accordingly the body waxes strong or weak, and a strong body lives longer than a feeble one. The normal length of human life should be a hundred years. The Classics attest that the Wise emperors of the Golden Age : Yao, Shun, Wên Wang, Wu Wang, and others all lived over hundred years.

\section{Book II.}

5. Chap. I. Hsing-ou 幸偶 (On Chance and Luck, I, X).

Happiness and misfortune are not the outcome of man's good or bad actions, but chance and luck. Some have good luck, others bad. Good and bad fortune are not distributed in a just way, 


\section{A. Forke, Introduction and Appendixes to Wang Ch'ung's \\ Lun-hêng}

according to worth, but are mere chance. This is true of man as well as of other beings. Even Sages are often visited with misfortune.

6. Chap. II. Ming-yi 命莪 (What is meant by Destiny ?, I, VIII).

The school of Mê Ti denies the existence of Destiny. Wang Ch'ung follows the authority of Confucius. There are various kinds of destinies. The length of human life is regulated by the fluid of Heaven, their wealth and honour by the effluence of the stars, with which men are imbued at their birth. Wang Ch'ung rejects the distinction of natural, concomitant, and adverse fate, but admits contingencies, chances, and incidents, which may either agree with the original fate and luck, or not. The fate of a State is always stronger than that of individuals.

7. Chap. III. Wu-hsing 無形 (Unfounded Assertions, I, XXVII).

At birth man receives the vital fluid from Heaven. This fluid determines the length of his life. There are no means to prolong its duration, as the Taoists pretend. Some examples from history are shown to be untrustworthy. At death everything ends. The vital force disperses, and the body is dissolved.

8. Chap. IV. Shuai-hsing 率性: (The Forming of Characters, I, XXXI).

There are naturally good, and there are naturally bad characters, but this difference between the qualities of low and superior men is not fundamental. The original fluid permeating all is the same. It contains the germs of the Five Virtues. Those who are p1.047 endowed with copious fluids, become virtuous, those whose fluid is deficient, wicked. But by external influences, human nature can turn from good into bad, and the reverse. Bad people can be improved, and become good by instruction and good example. Therefore the State cannot dispense with instructions and laws.

9. Chap. V. Chi-yen 吉驗 (Auspicious Portents, I, XIII).

Auspicious portents appear, when somebody is destined to something grand by fate, especially, when a new dynasty rises. 


\section{A. Forke, Introduction and Appendixes to Wang Ch'ung's \\ Lun-hêng}

These manifestations of fate appear either in the person's body, or as lucky signs in nature, or under the form of a halo or a glare. A. great variety of instances from ancient times down to the Han dynasty are adduced in proof.

\section{Book III.}

10. Chap. I. Ou-hui 偶會 (Coïncidences, II, I).

Fate acts spontaneously. There are no other alien forces at work besides fate. Nobody is able to do anything against it. Human activity is of no consequence.

11. Chap. II. Ku-Hsiang Min 胃相 (On Anthroposcopy, I, XXIV).

The heavenly fate becomes visible in the body, and can be foreseen by anthroposcopy. The Classics contain examples. The physiognomists draw their conclusions from the osseous structure and from the lines of the skin. The character can also be seen from the features.

12. Chap. III. Ch'u-ping 初高 (Heaven's Original Gift, I, VII).

Destiny comes down upon man already in his embryonic state, not later on during his life. It becomes mind internally and body externally. This law governs all organisms. Heaven never invests virtuous emperors, because it is pleased with them, for this would be in opposition to its principle of spontaneity and inaction. Utterances of the Classics that Heaven was pleased and looked round, etc. are to be taken in a figurative sense. Heaven has no human body and no human qualities. Lucky omens are not sent by Heaven, but appear by chance. p1.048

13. Chap. IV. Pên-hsing 本性 (On Original Nature, I, XXXII).

The different theories of Chinese moralists on human nature are discussed. Shih Tse holds that human nature is partly good, partly bad, Mencius that it is originally good, but can be corrupted, Sun Tse that it is originally bad, Kao Tse that it is neither good nor bad, and that it all depends on instruction and development, Lu Chia 


\section{A. Forke, Introduction and Appendixes to Wang Ch'ung's \\ Lun-hêng}

that it is predisposed for virtue. Tung Chung Shu and Liu Hsiang distinguish between natural disposition and natural feelings. Wang Ch'ung holds that nature is sometimes good and sometimes bad, but essentially alike, being the fluid of Heaven, and adopts the Confucian distinction of average people, people above, and people below the average. The latter alone can be changed by habit.

14. Chap. V. Wu-shih 物篎 (The Nature of Things, I, IV).

Heaven and Earth do not create man and the other things on earth intentionally. They all grow of themselves. Had Heaven produced all creatures on purpose, it would have taught them mutual love, whereas now one destroys the other. Some have explained this struggle for existence by the hypothesis that all creatures are filled with the fluid of the Five Elements, which fight together and overcome one another. Wang Ch'ung controverts this view and the symbolism connected therewith.

15. Chap. VI. Chi-kuai 奇怪 (Miracles, I, XXVI).

Wang Ch'ung proves by analogies that the supernatural births reported of several old legendary rulers, who are said to have been procreated by dragons or a special fluid of Heaven, are impossible. The Spirit of Heaven would not consort with a woman, for only beings of the same species pair. Saints and Sages are born like other people from their parents.

\section{Book IV.}

16. Chap. I. Shu-hsü 書虏 (Falsehoods in Books, II, XXIII)

The chapter contains a refutation of a series of wrong statements in ancient books. The assertion that Shun and Yü died in the South is shown to be erroneous. Wang Ch'ung explodes the idea that the 'Bore' at Hang-chou is caused by the angry spirit of Wu Tse Hsü, who was thrown into the Ch'ien-t'ang River, and remarks that the tide follows the phases of the moon. (Bk. IV, p. 5v.) p1.049 


\section{A. Forke, Introduction and Appendixes to Wang Ch'ung's \\ Lun-hêng}

17. Chap. II. Pien-hsü 留虚 ${ }^{1}$ (Fictitious Phenomena, II, XV).

Wang Ch'ung points out that many reports in ancient literature concerning extraordinary phenomena, not in harmony with the laws of nature, are fictitious and unreliable, e. $g$. the story that touched by the virtue of Duke Ching of Sung, the planet Mars shifted its place, that Heaven rewarded the Duke with 21 extra years, or that the great Diviner of Ch'i caused an earthquake.

\section{Book V.}

18. Chap. I. Yi-hsü 感虚 (Fictitious Prodigies, II, XVI).

The impossibility of some miracles and supernatural events is demonstrated, which have been handed down in ancient works, and are universally believed by the people and the literati, e. $g$. the birth of Pao Sse from the saliva of dragons.

19. Chap. II. Kan-hsü 感虚 (Fictitious Influences, II, XVII).

Wang Ch'ung contests that nature can be moved by man and deviate from its course. Various old legends are critically tested : the alleged appearance of ten suns in Yao's time, the report that the sun went back in his course, the wonders which happened during the captivity of Tsou Yen and Tan, Prince of Yen.

The tenor of the last four chapters all treating of unfounded assertions or figments 'Hsü' is very similar.

\section{Book VI.}

20. Chap. I. Fu-hsü 福盧. (Wrong Notions about Happiness, I, XI).

Happiness is not given by Heaven as a reward for good actions, as the general belief is. The Mêhist theory that the spirits protect and

49, line 1, page 54, line 15, and page 544, second column, line 20 for 1 變 read 戀. 


\section{A. Forke, Introduction and Appendixes to Wang Ch'ung's \\ Lun-hêng}

help the virtuous is controverted by facts. Wang Ch'ung shows how several cases, adduced as instances of how Heaven recompensed the virtuous are illusive, and that fate is capricious and unjust.

21. Chap. II. Huo-hsü 鞛虚. (Wrong Notions on Unhappiness, I, XII). The common belief that Heaven and Earth and the spirits punish the wicked and visit them with misfortune, is erroneous, as shown by examples of virtuous men, who were unlucky, and of wicked, who flourished. All this is the result of chance and luck, fate and time. p1.050

22. Chap. III. Lung-hsü 龍虏 (On Dragons, I, XXIX).

The dragon is not a spirit, but has a body and lives in pools. It is not fetched by Heaven during a thunderstorm, as people believe. The different views about its shape are given : It is represented as a snake with a horse's head, as a flying creature, as a reptile that can be mounted, and like earth-worms and ants. In ancient times dragons were reared and eaten. The dragon rides on the clouds during the tempest, there being a certain sympathy between the dragon and clouds. It can expand and contract its body, and make itself invisible.

23. Chap. IV. Lei-hsü 雷虚 (On Thunder and Lightning, I, XXII).

Thunder is not the expression of Heaven's anger. As a spirit it could not give a sound, nor could it kill a man with its breath. It does not laugh either. Very often the innocent are struck by lightning, and monsters like the Empress Lü Hou are spared. The pictorial representations of thunder as united drums, or as the thunderer Lei Kung, are misleading. Thunder is fire or hot air, the solar fluid Yang exploding in its conflict with the Yin fluid, lightning being the shooting forth of the air. Five arguments are given, why thunder must be fire.

\section{Book VII.}




\section{A. Forke, Introduction and Appendixes to Wang Ch'ung's \\ Lun-hêng}

24. Chap. I. Tao-hsü 道虛. (Taoist Untruths, I, XXVIII).

Man dies and can become immortal. The Taoist stories of Huang Ti and Huai Nan Tse's ascension to heaven, of the flying genius met by Lu Ao, and of Hsiang Man Tse's travel to the moon are inventions. The magicians do not possess the powers ascribed to them. The Taoist theory of prolonging life by quietism and dispassionateness, by regulating one's breath, and using medicines is untenable.

25. Chap. II. Yü-tsêng 語增 (Exaggerations, I, XXXIX).

Wang Ch'ung points out a number of historical exaggerations e. $g$. that the embonpoint of Chieh and Chou was over a foot, that Chou had a wine-lake, from which 3,000 persons sucked like cattle, that Wên Wang could drink 3,000 bumpers of wine, and Confucius 100 gallons, and some mis-statements concerning the simplicity of Yao and Shun, and the cruelty of Shih Huang Ti, and tries to reduce them to the proper limits. p1.051

\section{Book VIII.}

26. Chap. I. Ju-tsêng 儒增 (Exaggerations of the Literati, I, XL).

Wang Ch'ung goes on to criticise some old traditions: on the abolition of punishments under Yao and Shun, on the wonderful shooting of Yang Yu Chi and Hsiung Ch'ü Tse, on the skill of Lu Pan, on Ching K'o's attempt upon Shih Huang Ti's life, on the miracles connected with the Nine Tripods of the Chou dynasty, etc.

27. Chap. II. Yi-tsêng 藮壖 (Literary Exaggerations, II, XXIV).

People are fond of the marvellous and of exaggerations, in witness whereof passages are quoted from the Shuking, the Shiking, the Yiking, the Lun-yü, and the Ch'un-ch'iu.

\section{Book IX.}

28. Chap. I. Wên K'ung 閒孔 (Criticisms on Confucius I, XXXIII). 


\section{A. Forke, Introduction and Appendixes to Wang Ch'ung's \\ Lun-hêng}

The Confucianists do not dare to criticise the Sages, although the words of the Sages are not always true and often contradictory. It is also, because they do not understand the difficult passages, and only repeat what the commentators have said. Wang Ch'ung vindicates the right to criticise even Confucius. Such criticisms are neither immoral nor irrational. They help to bring out the meaning, and lead to greater clearness. Wang Ch'ung then takes up a number of passages from the Analects for discussion, in which he discovers contradictions or other flaws, but does not criticise the system of Confucius or his theories in general.

\section{Book X.}

29. Chap. I. Fei Han 非韓 (Strictures on Han Fei Tse I, XXXV).

Han Fei Tse solely relies on rewards and punishments to govern a State. In his system there is no room for the cultivation of virtue. He despises the literati as useless, and thinks the world to be so depraved and mean, that nothing but penal law can keep it in check. Wang Ch'ung shows by some examples taken from Han Fei Tse work that this theory is wrong. Men of letters are as useful to the State as agriculturists, warriors, and officials, for they cultivate virtue, preserve the true principles, and benefit the State by the good example they set to the other classes. p1.052

30. Chap. II. T'se Mêng 刺孟 (Censures on Mencius I, XXXIV).

Wang Ch'ung singles out such utterances of Mencius, in which according to his view his reasoning is defective, or which are conflicting with other dicta of the philosopher.

\section{Book XI.}

31. Chap. I. T'an-t'ien 談天 (On Heaven, I, XIX).

The old legend of the collapse of Heaven, which was repaired by Nü Wa, when Kung Kung had knocked with his head against the 'Pillar of Heaven', is controverted, as is Tsou Yen's theory of the 


\section{A. Forke, Introduction and Appendixes to Wang Ch'ung's \\ Lun-hêng}

existence of Nine Continents. Heaven is not merely air, but has a body, and the earth is a square measuring $100,000 \mathrm{Li}$ in either direction.

32. Chap. II. Shuo-jih 說日 (On the Sun, I, XX).

A variety of astronomical questions are touched. Wang Ch'ung opposes the view that the sun disappears in darkness during the night, that the length or shortness of the days is caused by the Yin and the Yang, that the sun rises from Fu-sang and sets in Hsi-liu, that at Yao's time ten suns appeared, that there is a raven in the sun, and a hare and a toad in the moon. Heaven is not high in the south and depressed in the north, nor like a reclining umbrella, nor does it enter into or revolve in the earth. Heaven is level like earth, and the world lying in the south-east. The sun at noon is nearer than in the morning or in the evening. Wang Ch'ung further speaks on the rotation of the sky, the sun, and the moon, on the substance of the sun and the moon, on their shape, the cause of the eclipses, meteors, and meteorological phenomena.

33. Chap. III. Ta-ning 答位 (On the cunning and artful, II, VI).

\section{Book XII.}

34. Chap. I. Ch'êng-t'sai 程材 (Weighing of Talents, II, VII).

The difference between scholars and officials is pointed out. Wang Ch'ung stands up for the former, and places them higher than the officials, because they are of greater importance to the State. The people however think more of the officials. p1.053

35. Chap. II. Liang-chih 星知 (The Valuation of Knowledge, II, VIII).

The same subject as treated in the preceding chapter.

36. Chap. III. Hsieh-tuan 謝短 (Admitting Shortcomings, II, IX).

Men of letters as well as officials have their shortcomings. The former are interested in antiquity only, and neglect the present, the Ch'in and Han time. They only know the Classics, but even many questions concerning the age and the origin of the Classics 


\section{A. Forke, Introduction and Appendixes to Wang Ch'ung's \\ Lun-hêng}

they cannot answer. The officials know their business, but often cannot say, why they do a thing, since they do not possess the necessary historical knowledge.

\section{Book XIII.}

37. Chap. I. Hsiao-li 效汃 (The Display of Energy, II, X).

The chapter treats of the faculties of the scholars and the officials, and of their energy and perseverance displayed in different departments.

38. Chap. II. Pieh-t'ung 別通 (On Intelligence, II, XI).

There is the same difference between the learned and the uncultivated as between the rich and the poor. Learning is a power and more important than wealth.

39. Chap. III. Ch'ao-chi 超奇 (On Preeminence, II, XXVII).

There are various degrees of learning. Some remarks are made on the works of several scholars, e. $g$. the philosopher Yang Tse Yün and the two historians Pan.

\section{Book XIV.}

40. Chap. I. Chuang-liu 状留 (Apparent Backwardness, II, XII).

Scholars do not strive for office. As for practical success they are outrivalled by the officials, who are men of business.

41. Chap. II. Han-wên 寒温 (On Heat and Cold, I, XXI).

Wang Ch'ung contests the assertion of the phenomenalists that there is a correspondence between heat and cold and the joy and anger of the sovereign. He points out that the South is the seat of heat, and the North of cold. Moreover the temperature depends on the four seasons and the 24 time-periods. p1.054

42. Chap. III. Ch'ien-kao 檤告- (On Reprimands, I, VI). 


\section{A. Forke, Introduction and Appendixes to Wang Ch'ung's \\ Lun-hêng}

The savants hold that Heaven reprimands a sovereign whose administration is bad, visiting him with calamities. First he causes extraordinary events. If the sovereign does not change then, he sends down misfortunes upon his people, and at last he punishes his own person. Heaven is represented like a prince governing his people. These heavenly punishments would be at variance with Heaven's virtue, which consists in spontaneity and inaction. Heaven does not act itself, it acts through man, and speaks through the mouths of the Sages, in whose hearts is ingrafted its virtue. The utterances of the Classics ascribing human qualities to Heaven are only intended to give more weight to those teachings, and to frighten the wicked and the unintelligent.

\section{Book XV.}

43. Chap. I. Pien-tung 總動 (Phenomenal Changes, I, V).

Heaven influences things, but is not affected by them. All creatures being filled with the heavenly fluid, Heaven is the master, and not the servant. The Yang and the Yin move things, but are not moved. The deeds and the prayers of a tiny creature like man cannot impress the mighty fluid of Heaven, and the sobs of thousands of people cannot touch it. Heaven is too far, and its fluid shapeless without beginning or end. It never sets the laws of nature aside for man's sake.

44. Chap. II. Chao-chih 招致 (This chapter has been lost.).

45. Chap. III. Ming-yü 明雾 (On the Rain Sacrifice, II, XXX).

The rain sacrifice, which during the Ch'un-ch'iu period was performed at times of drought, 'forms the subject of this essay. People use to pray for rain and happiness, as they implore the spirits to avert sickness and other evils. Some believe that rain is caused by the stars, others that it depends on the government of a State, others again that it comes from the mountains. The last opinion is shared by Wang Ch'ung. 


\section{A. Forke, Introduction and Appendixes to Wang Ch'ung's \\ Lun-hêng}

46. Chap. IV. Shun-ku順鼓 (Gentle Drums, II, XXXI).

The chapter treats of the religions ceremonies performed to inundations, in which the beating of drums is very important. p1.055

\section{Book XVI.}

47. Chap. I. Luan-lung 嗝龍 (A Last Word on Dragons, II, XXXII).

As a means to attract the rain by the sympathetic action of similar fluids Tung Chung Shu had put up a clay dragon. Wang Ch'ung attempts to demonstrate the efficacy of this procedure by 15 arguments and 4 analogies.

48. Chap. II Tsao-hu 遭虎 (The Tiger Trouble, II, XXXIII).

Wang Ch'ung controverts the popular belief that, when men are devoured by tigers, it is the wickedness of secretaries and minor officials which causes these disasters.

49. Chap. III. Shang-ch'ung 商虫 (Remarks on Insects, II, XXXIV).

The common belief that the eating of the grain by insects is a consequence of the covetousness of the yamen underlings is shown to be futile.

50. Chap. IV. Chiang-jui 講瑞 (Arguments on Ominous Creatures, I, XXX).

Wang Ch'ung denies that the literati would be able to recognise a phœnix or a unicorn, should they appear, nor would they know a sage either. The phœnix and the unicorn are regarded as holy animals and as lucky auguries. The old traditions about their appearance at various times and their shape, which are very conflicting, are discussed. Wang Ch'ung holds that these animals do not only appear at the time of universal peace, that as ominous creatures they are born of a propitious fluid, and do not belong to a certain species, but may grow from dissimilar parents of a common species of animals.

\section{Book XVII.}




\section{A. Forke, Introduction and Appendixes to Wang Ch'ung's \\ Lun-hêng}

51. Chap. I. Chih-jui 指瑞 (Thoughts on Omens, II, XXVIII).

The discussion on the phœnix and the unicorn is continued. Wang Ch'ung impugns the opinion that these animals are not born in China, but come from abroad, when there is a wise emperor. They grow in China, even, when there is no sage. p1.056

52. Chap. II. Shih-ying 是應 (Auguries verified, II, XXIX).

This chapter treats of the various lucky omens of the Golden Age : the purple boletus, the wine springs, the sweet dew, the Ching star, the monthly plant, the phœnix, the unicorn, and of some other fabulous animals.

53. Chap. III. Chih-ch'i 治期 (Periods of Government, II, II).

The praise of antiquity, its high virtue and happiness is unfounded. There is nothing but fate. Human activity is powerless.

\section{Book XVIII.}

54. Chap. I. Tse-jan 自然 (Spontaneity, I, III).

Heaven emits its generating fluid spontaneously, not on purpose. It has no desires, no knowledge, and does not act. These qualities require organs : a mouth, eyes, hands, etc., which it does not possess. Its body must be either like that of Earth, or air. Heaven's fluid is placid, desireless, and unbusied. This spontaneity is a Taoist theory, but they did not sufficiently substantiate it. Only Sages resembling Heaven can be quite spontaneous and inactive, others must act, and can be instructed. Originally men lived in a happy state of ignorance. Customs, laws, in short culture is already a decline of virtue.

55. Chap. II. Kan-lei 感類 (Sympathetic Emotions, II, III).

Natural calamities and unlucky events are not the upshot of human guilt, as a thunderstorm is not a manifestation of Heaven's anger.

56. Chap. III. Ch'i-shih 弯过 (The Equality of the Ages, I, XXXVIII). 


\section{A. Forke, Introduction and Appendixes to Wang Ch'ung's \\ Lun-hêng}

People of old were not better, nor stronger, taller or longer lived than at present. Heaven and Earth have remained the same, and their creatures likewise. There is a periodical alternation of prosperity and decline in all the ages. The present time is not inferior to antiquity, but the literati extol the past and disparage the present. Even sages like Confucius would not find favour with them, if they happened to live now. And yet the Han dynasty is quite equal to the famous old dynasties. p1.057

\section{Book XIX.}

57. Chap. I. Hsüan Han 宣漢 (Praise of the Han Dynasty, II, XVIII).

The scholars hold that in olden days there has been a Golden Age, which is passed and does not come back owing to the badness of the times. Wang Ch'ung stands up for his own time, the Han epoch. He enumerates the lucky portents observed under the Han emperors, and refers to the great achievements of the Han dynasty in the way of colonising and civilising savage countries.

58. Chap. II. Hui-kuo 恢戌 (Further Remarks on the State, II, XIX).

Wang Ch'ung gives to the Han dynasty the preference over all the others, and again discourses on the lucky auguries marking its reign.

59. Chap. III. Yen-fu 驗符 (Ominous Signs Investigated, II, XX).

The discovery of gold under the Han dynasty, and of purple boletus, the sweet-dew-fall in several districts, and the arrival of dragons and phœnixes are put forward as so many proofs of the excellence of the Han dynasty.

\section{Book XX.}

60. Chap. I. Hsü-sung 恢咸 (The Necessity of Eulogies, II, XXI).

This chapter is a variation of the two preceding.

61. Chap. II. Yi-wên 佒交 (Lost Texts, II, XXV). 


\section{A. Forke, Introduction and Appendixes to Wang Ch'ung's \\ Lun-hêng}

The subject of this treatise is purely literary. It discusses the discovery of the Classics in the house of Confucius, the Burning of the Books under Ch'in Shih Huang Ti and the literature of the Han epoch, of which several authors are mentioned.

62. Chap. III. Lun-sse 論死 (On Death, I, XV).

Man is a creature. Since other creatures do not become ghosts after death, man cannot become a ghost either. If all the millions that have lived, became spirits, there would not be sufficient room for all the spirits in the world. The dead never give any sign of their existence, therefore they cannot exist any more. The vital fluid forming the soul disperses at death, how could it p1.058 become a ghost. A spirit is diffuse and formless. Before its birth the soul forms part of the primogenial fluid, which is unconscious. When at death it reverts thereto, it becomes unconscious again. The soul requires the body to become conscious and to act. If sleep causes unconsciousness, and if a disease disorganises the mind, death must do the same in a still higher degree.

\section{Book XXI.}

63. Chap. I. Sse-wei 死鸹 (False Reports about the Dead, I, XVI).

A number of ghost stories are quoted from the Tso-chuan and other ancient works, where discontented spirits are reported to have taken their revenge upon, and killed their enemies. Wang Ch'ung either rejects these stories as inventions, or tries to explain them in a natural way.

\section{Book XXII.}

64. Chap. I. Chi-yao 紀妖 (Spook Stories, I, XVII).

Several spook and ghost stories recorded in the Shi-chi and the Tso-chuan are analysed. Wang Ch'ung explains them in accordance with his theory on the spontaneity of Heaven, and on the nature of apparitions and portents. 


\section{A. Forke, Introduction and Appendixes to Wang Ch'ung's \\ Lun-hêng}

65. Chap. II. Ting-kuei 言鬼 (All about Ghosts, I, XVIII).

Wang Ch'ung sets forth the different opinions on the nature of ghosts, propounded at his time. Some hold that ghosts are visions of sick people, or the fluid of sickness. Others regard them as the stellar fluid, or as the essence of old creatures, or as the spirits of cyclical signs. After an excursion on the demons, devils, and goblins mentioned in ancient books, Wang Ch'ung gives his own views, according to which ghosts are apparitions and phantoms foreboding evil, which have assumed human form, but are only semblances and disembodied. They consist of the solar fluid, the Yang, are therefore red, burning, and to a certain extent poisonous.

\section{Book XXI I I.}

66. Chap. I. Yen-tu 言毒 (On Poison, I, XXIII). Animal and vegetable poison is the hot air of the sun. All beings filled with the solar fluid contain some poison. Snakes, scorpions, and some plants have plenty of it. Ghosts, which consist ${ }_{\text {p1.059 }}$ of the pure solar fluid, are burning poison, which eventually kills. There is poison in some diseases, in a sun-stroke for instance and in lumbago. Wang Ch'ung discovers real poison in speech, in beauty, and in several tastes, which only metaphorically might be called poisonous, and mixes up the subject still more by improper symbolism.

67. Chap. II. Po-tsang 溥葬 (Simplicity of Funerals, II, XXXV).

This chapter is directed against the extravagance in funerals, on the score that the dead have no benefit from it.

68. Chap. III. Sse-hui 四諱 (Four Things to be avoided, II, XXXVI).

There is a popular belief that four things are dangerous and bring misfortune viz. to enlarge a house at the west side, to allow a banished man to ascend a tumulus, the intercourse with women, during the first month after they have given birth to a child, and 


\section{A. Forke, Introduction and Appendixes to Wang Ch'ung's \\ Lun-hêng}

the rearing of children born in the 1st and the 5th months, who will cause the deaths of their parents. Wang Ch'ung combats these superstitions.

69. Chap. IV. Lan-shih 澗時 (False Charges against Time, II, XXXVII).

Wang Ch'ung discourses on the common belief that in building one must pay attention to an unpropitious time, which may be warded off by amulets. He further speaks of the spirits of the year, the months, etc.

\section{Book XXI V.}

70. Chap. I. Chi-jih 譏 日 (Slandering of Days, II, XXXVIII).

Some more superstitions concerning unlucky years, months, and days, which must be shunned to avoid misfortunes, are investigated. For many actions the election of a proper time is deemed to be of great importance, e. $g$. for a funeral, or for commencing a building. Bathing on certain days, women become beautiful ; bathing on others makes their hair turn white. On the day of T'sang Hsieh's death, who invented writing, one must not study calligraphy, and on the day of the downfall of the Yin and Hsia dynasties one does not make music.

71. Chap. II. Pu-shih 小筷 (On Divination, I, XIV). People often neglect virtue and only rely on divination. They imagine that by means of tortoise shells and milfoil they 1.060 can interrogate Heaven and Earth about the future, and that they reply by the signs of the shells and the straws. Wang Ch'ung shows that such an opinion is erroneous, but, whereas Han Fei Tse condemns divination altogether, he upholds this science. In his idea visions, signs, and omens are true by all means, only they are very often misunderstood or misinterpreted by the diviners. The lucky will meet with good omens, which, however, are not the response of Heaven, but happen by chance.

72. Chap. III. Pien-sui 䇋崇 (Criticisms on Noxious Influences, I, XLIII). 


\section{A. Forke, Introduction and Appendixes to Wang Ch'ung's \\ Lun-hêng}

Most people are under the delusion that by disregarding an unpropitious time viz. years, months, and days of dread, they will have to suffer from noxious influences, falling in with evil spirits, which work disaster. This is an error, as shown by experience, but horoscopists and seers are silent on all cases contradicting their theory. A vast literature has sprung up on this subject, and the princes dare not take any important step in life, any more than their people, without reference to it.

73. Chap. IV. Nan-sui 難藏 (Questions about the Year Star, II, XXXIX).

Wang Ch'ung impugns the view that by moving one's residence one may come into collision with the Spirit of the North Point, Nan Sui, which would be disastrous.

\section{Book XXV.}

74. Chap. I. Ch'i-shu 詰術 (Criticisms on Certain Theories, II, XL).

The chapter treats of the precautions which used to be taken in building houses, special attention being paid to the family name, the number of the house, the situation, etc.

75. Chap. II. Chieh-ch'u 解除 (On Exorcism, I, XLIV).

By exorcism malignant spirits are expelled after having been feasted. Exorcism and conjurations are of no use, for either would the ghosts not yield to the force employed against them, and resent the affront, or, if they are like mist and clouds, their expulsion would be useless. In ancient times, sickness was expelled in this way. The propitiation of the Spirit of Earth, after having dug up the ground, is also useless, for Earth does not hear man nor understand his speech. All depends upon man, not on ghosts. p1.061

76. Chap. III. Sse-yi 却義 (Sacrifices to the Departed, I, XLI).

Sacrifices are merely manifestations of the feelings of love and gratitude, which the living cherish towards ghosts and spirits. The latter cannot enjoy the sacrifices, which are presented to them, 


\section{A. Forke, Introduction and Appendixes to Wang Ch'ung's \\ Lun-hêng}

because having no body, they are devoid of knowledge and cannot eat or drink. If Heaven and Earth could eat or drink, they would require such enormous quantities of food, that man could never appease their hunger. Wang Ch'ung treats of the nature of ghosts, and refers to the sacrifices to Heaven and Earth, to the House, to the Gods of Wind, Rain, and Thunder, to the Sun, the Moon, and the Stars, and to the Ancestors.

77. Chap. IV. Chi-yi 䅛意 (Sacrifices, I, XLII).

The various old sacrifices are described, those to Heaven and Earth, to the Mountains and Rivers, to the Spirits of the Land and Grain, to the Six Superior Powers, to the Seasons, Heat and Cold, Water and Drought, the Rain Sacrifice, those to the Four Cardinal Points, to the Sun, the Moon, and the Stars, the Five Genii of the House, and to the Ancestors. All these sacrifices saving the last were State sacrifices and reserved for the emperor, the feudal princes, and their officials. They are thank-offerings for kindness received. There are no spirits present to enjoy them, nor can they bestow happiness on the sacrificers, or visit with misfortune those who neglect them. Therefore sacrifices are a beautiful custom, but of no great consequence.

\section{Book XXVI.}

78. Chap. I. Shih-chih 實知 (The Real Nature of Knowledge, II, XIII).

Saints and Sages are credited with an extraordinary knowledge. They need not learn or study, for they are cognisant of everything intuitively, and know the past as well as the future. This is a fallacy. There are no supernatural faculties, and even those of the Sages follow the natural laws.

79. Chap. II. Chih-shih 知實 (The Knowledge of Truth, II, XXVI). Confucius was not prescient and not a prophet, as has been asserted. 16 examples are given, all showing his inability to foreknow the future. p1.062 


\section{A. Forke, Introduction and Appendixes to Wang Ch'ung's \\ Lun-hêng}

\section{Book XXVII.}

80. Chap. I. Ting-hsien 定賢 (A Definition of Worthies, II, XIV).

The nature of the Worthies is defined. Examples are adduced of what they are not. No exceptional talents are required, but a certain amount of intelligence and honesty. Worthies belong to the same class as Saints or Sages, but are somewhat inferior.

\section{Book XXVIII.}

81. Chap. I. Chêng-shuo 正說 (Statements Corrected, I, XXXVI).

This chapter contains critical remarks on the composition and the history of the Shuking, the Shiking, the Ch'un-ch'iu, the Yiking, the Liki, and the Analects. The meaning of the dynastic names of T'ang, Yü, the Hsia, Yin, and Chou dynasties is explained, and some hints as to how the Canons are to be interpreted are added.

82. Chap. II. Shu-chieh 拍解 (On Literary Work, II, XXII).

The chapter deals with learning and erudition, with literary composition, and with the various kinds of men of letters.

\section{Book XXIX.}

83. Chap. I. An-shu 案書 (Critical Remarks on Various Books, I, XXXVII). Wang Ch'ung criticises the famous authors of his time and their works, beginning with some writers of the Chou epoch. He finds fault with Mê Ti, the sophist Kung Sun Lung, and the speculative philosopher Tsou Yen, and commends Tso Ch'iu Ming, the author of the Tso-chuan and the Kuo-yü. He speaks with great respect of the historians Sse Ma Ch'ien and Pan Ku, the philosopher Yang Tse Yün, and Liu Hsiang, and in the highest terms of Lu Chia, who published the Ch'un-ch'iu-fan-lu, and of Huan Chün Shan and Huan K'uan, the authors of the Hsin-lun and the Yen-t'ieh-lun. 


\section{A. Forke, Introduction and Appendixes to Wang Ch'ung's \\ Lun-hêng}

84. Chap. II. Tui-tso 数作 (Replies in Self-Defence, I, II).

Wang Ch'ung gives the reasons, why he wrote his principal works, the Lun-hêng and the Chêng-wu, a treatise on government. In the Lun-hêng he wishes to explain common errors, to point out p1.063 the exaggerations and inventions in literature, and thus deliver mankind of its prejudices. The Lun-hêng weighs the words and holds up a balance for truth and falsehood. Wang Ch'ung shows the advantage which might be derived from different chapters, and meets the objections which his opponents would perhaps raise.

\section{Book XXX.}

85. Chap. I. Tse-chi 自紀 (Autobiography I, I).

Wang Ch'ung is a native of Shang-yü-hsien in Chekiang. His family originally lived in Chihli. He was born in A. D. 27, and already as a boy was very fond of study. In his official career he was not very successful. The highest post which he held about A. D. 86 was that of a sub-prefect. The equanimity of a philosopher helped him over many disappointments. His ideal was to possess an extensive knowledge, a keen intellect, and a noble mind. Besides his chief work the Lun-hêng, he wrote 12 chapters on common morals in a plain and easy style, and a treatise 'Macrobiotics' in A. D. 91. He defends the style, the voluminousness, and the contents of the Lun-hêng against the attacks directed against it. 


\section{COMPARATIVE TABLE OF CONTENTS}

\section{Chinese Text}

Book I.

1. Chap. I. Feng-yü 逢遇 (Success and Luck).

2. Chap. II. Lei-hai 累害 (Annoyances and Vexations).

3. Chap. III. Ming-lu 命旅 (On Destiny and Fortune).

4. Chap. IV. Ch'i-shou氣壽 (Long Life and Vital Fluid).

\section{Book II,}

5. Chap. I. Hsing-ou 幸偶 (On Chance and Luck). I, X, 151.

6. Chap. II. Ming-yi 命莪 (What is meant by Destiny ?). I, VIII, 136.

7. Chap. III. Wu-hsing 無形 (Unfounded Assertions).

8. Chap. IV. Shuai-hsing 率性: (Forming of Characters).

9. Chap. V. Chi-yen 吉驗 (Auspicious Portents).

XXVII, 325.

\section{Translation (Vol., Chap., Page)}

I, IX, 144.

I, XXV, 313.
II, IV, 30 .

II, V, 37.

\section{Book III.}

10. Chap. I. Ou-hui 偶會 (Coincidences).

11. Chap. II. Ku-hsiang 胃 相 (On Anthroposcopy).

12. Chap. III. Ch'u-ping 初禀 (Heaven's Original Gift).

I, XXIV, 304.

13. Chap. IV. Pên-hsing 本性 (On Original Nature).

I, VII, 130.

14. Chap. V. Wu-shih 物染 (The Nature of Things).

I, XXXII, 384.

15. Chap. VI. Chi-kuai 奇怪 (Miracles).

I, IV, 103.

I, XXVI, 318.

\section{Book IV.}

16. Chap. I. Shu-hsü 書膚 (Falsehoods in Books).

II, XXIII, 240.

17. Chap. II. Pien-hsü 解膚 (Fictitious Phenomena).

$$
\text { II, XV, } 152 .
$$

\section{Book V.}

18. Chap. I. Yi-hsü 感虚 (Fictitious Prodigies).

II, XVI, 161.

19. Chap. II. Kan-hsü 感虚 (Fictitious Influences).

II, XVII, 171.

\section{Book VI.}

20. Chap. I. Fu-hsü 福虚. (Wrong Notions about Happiness). I, XI, 156.

21. Chap. II. Huo-hsü 袺虛. (Wrong Notions on Unhappiness).I, XII, 164.

22. Chap. III. Lung-hsü 龍虏 (On Dragons). I, XXIX, 351.

23. Chap. IV. Lei-hsü 雷虚 (On Thunder and Lightning). I, XXII, 285.

\section{Book VII.}

24. Chap. I. Tao-hsü 道虚. (Taoist Untruths). I, XXVIII, 332.

25. Chap. II. Yü-tsêng 翻增 (Exaggerations). I, XXXIX, 481.

\section{Book VIII.}




\section{A. Forke, Introduction and Appendixes to Wang Ch'ung's \\ Lun-hêng}

26. Chap. I. Ju-tsêng 儒增 (Exaggerations of the Literati). I, XL, 494.

27. Chap. II. Yi-tsêng 蒦壖 (Literary Exaggerations).

II, XXIV, 392.

\section{Book IX.}

28. Chap. I. Wên K'ung 間孔 (Criticisims on Confucius). I, XXXIII, 392.

\section{Book X.}

29. Chap. I. Fei Han 非韓 (Strictures on Han Fei Tse). I, XXXV, 433.

30. Chap. II. T'se Mêng 刺孚. (Censures on Mencius). I, XXXIV, 418.

\section{Book XI .}

31. Chap. I. Tan-t'ien 談天 (On Heaven). I, XIX, 250.

32. Chap. II. Shuo-jih 說日 (On the Sun). I, XX, 258.

33. Chap. III. Ta-ning 答传 (On the cunning and artful). II, VI, 43.

Book XII.

34. Chap. I. Ch'êng-t'sai 程材 (Weighing of Talents).

II, VII, 56.

35. Chap. II. Liang-chih 星知 (The Valuation of Knowledge).

II, VIII, 67.

36. Chap. III. Hsieh-tuan 謝短 (Admitting Shortcomings).

Book XIII.

37. Chap. I. Hsiao-li 效加 (The Display of Energy).

II, X, 86.

38. Chap. II. Pieh-t'ung 別通 (On Intelligence).

39. Chap. III. Ch'ao-chi 超奇 (On Preeminence).

\section{Book XI V.}

40. Chap. I. Chuang-liu 状留 (Apparent Backwardness).

41. Chap. II. Han-wên 寒温 (On Heat and Cold).

42. Chap. III. Ch'ien-kao 檤告 (On Reprimands).

\section{Book XV.}

43. Chap. I. Pien-tung 變動 (Phenomenal Changes). I, V, 109.

44. Chap. II. Chao-chih 招致 (This chapter has been lost.).

45. Chap. III. Ming-yü 明零 (On the Rain Sacrifice).

II, XXX, 327.

46. Chap. IV. Shun-ku 順鼓 (Gentle Drums).

I, XXI, 278.

I, VI, 119.

II, XI, 96.

II, XXVII, 295.

II, XII, 108.

\section{Book XVI.}

47. Chap. I. Luan-lung 敛龍 (A Last Word on Dragons).

48. Chap. II Tsao-hu 遭虎 (The Tiger Trouble).

II, XXXII, 349.

49. Chap. III. Shang-ch'ung 商虫 (Remarks on Insects).

II, XXXIII, 357.

50. Chap. IV. Chiang-jui 講瑞 (Arguments on Ominous Creatures).I, XXX, 359.

\section{Boox XVII.}

51. Chap. I. Chih-jui 指瑞 (Thoughts on Omens). I, XXVIII, 306.

52. Chap. II. Shih-ying 是應 (Auguries verified).

II, XXIX, 315.

53. Chap. III. Chih-ch'i 治期 (Periods of Government).

II, II, 9. 


\section{A. Forke, Introduction and Appendixes to Wang Ch'ung's \\ Lun-hêng}

\section{Book XVIII.}

54. Chap. I. Tse-jan 自然 (Spontaneity). I, III, 92.

55. Chap. II. Kan-lei 感類 (Sympathetic Emotions). II, III, 16.

56. Chap. III. Ch'i-shih 䍿世世 (The Equality of the Ages). I, XXXVIII, 471.

\section{Book XIX.}

57. Chap. I. Hsüan Han 宣漢 (Praise of the Han Dynasty).

II, XVIII, 192.

58. Chap. II. Hui-kuo 恢威 (Further Remarks on the State).

II, XIX, 201.

59. Chap. III. Yen-fu 驗符 (Ominous Signs Investigated).

\section{Book XX.}

60. Chap. I. Hsü-sung 恢烕 (The Necessity of Eulogies).

II, XXI, 220.

61. Chap. II. Yi-wên 佚文 (Lost Texts).

II, XXV, 272.

62. Chap. III. Lun-sse 論死 (On Death).

I, XV, 191.

\section{Book XXI.}

63. Chap. I. Sse-wei 死傜 (False Reports about the Dead). I, XVI, 202.

\section{Book XXII.}

64. Chap. I. Chi-yao 紀妖 (Spook Stories). I, XVII, 220.

65. Chap. II. Ting-kuei 訂鬼 (All about Ghosts). I, XVIII, 239.

\section{Book XXIII.}

66. Chap. I. Yen-tu 言样 (On Poison). I, XXIII, 298.

67. Chap. II. Po-tsang 溥葬 (Simplicity of Funerals).

II, XXXV, 369.

II, XXXVI, 376.

68. Chap. III. Sse-hui 四諱 (Four Things to be avoided).

II, XXXVII, 387.
II, XXXVIII, 393.

70. Chap. I. Chi-jih 譏 日 (Slandering of Days).

71. Chap. II. Pu-shih 下篗 (On Divination). I, XIV, 182.

72. Chap. III. Pien-sui 䇋岀 (Criticisms on Noxious Influences). I, XLIII, 525.

73. Chap. IV. Nan-sui 難歳 (Questions about the Year Star).

\section{Book XXV.}

74. Chap. I. Ch'i-shu 詰術 (Criticisms on Certain Theories).

75. Chap. II. Chieh-ch'u 解除 (On Exorcism).

I, XLIV, 532.

76. Chap. III. Sse-yi 祀義 (Sacrifices to the Departed). I, XLI, 509.

77. Chap. IV. Chi-yi 祭意 (Sacrifices).

I, XLII, 516.

\section{Book XXVI.}

78. Chap. I. Shih-chih 宾知 (The Real Nature of Knowledge). II, XIII, 114.

79. Chap. II. Chih-shih 知實 (The Knowledge of Truth).

Book XXVII.

80. Chap. I. Ting-hsien 定賢 (A Definition of Worthies).

II, XIV, 129. 


\section{A. Forke, Introduction and Appendixes to Wang Ch'ung's Lun-hêng}

\section{Book XXVIII.}

81. Chap. I. Chêng-shuo 正䛦 (Statements Corrected). I, XXXVI, 447.

82. Chap. II. Shu-chieh 草解 (On Literary Work).

II, XXII, 229.

\section{Book XXIX.}

83. Chap. I. An-shu 案書 (Critical Remarks on Various Books). I, XXXVII, 461.

84. Chap. II. Tui-tso 對作 (Replies in Self-Defence). I, II, 83.

Book XXX.

85. Chap. I. Tse-chi 自紀 (Autobiography).

I, I, 64. 


\title{
Lun-hêng
}

\author{
Translation of \\ Wang Ch'ung's Lun-hêng, Part I, philosophical essays
}

A. Biographical.

1. Autobiography. Tse-chi. Bk. XXX, Chap. I.

2. Replies in Self-Defence. Tui-tso. Bk. XXIX, Chap. II.

B. Metaphysical.

3. Spontaneity. Tse-jan. Bk. XVIII, Chap. I.

4. The Nature of Things. Wu-shih. Bk. III, Chap. V.

5. Phenomenal Changes. Pien-tung. Bk. XV, Chap. I.

6. On Reprimands. Ch'ien-kao. Bk. XIV, Chap. III.

7. Heaven's Original Gift. Ch'u-ping. Bk. III, Chap. III.

8. What is meant by Destiny ? Ming-yi. Bk. II, Chap. II.

9. On Destiny and Fortune. Ming-lu. Bk. I, Chap. III.

10. On Chance and Luck. Hsing-ou. Bk. II, Chap. I.

11. Wrong Notions about Happiness. Fu-hsü. Bk. VI, Chap. I.

12. Wrong Notions on Unhappiness. Huo-hsü. Bk. VI, Chap. II.

13. Auspicious Portents. Chi-yen. Bk. II, Chap. V.

14. On Divination. Pu-shih. Bk. XXIV, Chap. II.

15. On Death. Lun-sse. Bk. XX, Chap. III.

16. False Reports about the Dead. Sse-wei. Bk. XXI, Chap. I.

17. Spook Stories. Chi-yao. Bk. XXII, Chap. I.

18. All about Ghosts. Ting-kuei. Bk. XXII, Chap. II.

\section{Physical.}

19. On Heaven. T'an-t'ien. Bk. XI, Chap. I.

20. On the Sun. Shuo-jih. Bk. XI, Chap. II.

21. On Heat and Cold. Han-wên. Bk. XIV, Chap. II.

22. On Thunder and Lightning. Lei-hsü. Bk. VI, Chap. IV.

23. On Poison. Yen-tu. Bk. XXIII, Chap. I.

24. On Anthroposcopy. Ku-hsiang. Bk. III, Chap. II.

25. Long Life and Vital Fluid. Ch'i-shou. Bk. I, Chap. IV.

26. Miracles. Chi-kuai. Bk. III, Chap. VI.

27. Unfounded Assertions. Wu-hsing. Bk. II, Chap. III.

28. Taoist Untruths. Tao-hsü. Bk. VII, Chap. I.

29. On Dragons. Lung-hsü. Bk. VI, Chap. III.

30. Arguments on Ominous Creatures. Chiang-jui. Bk. XVI, Chap. IV.

D. Ethical.

31. The Forming of Characters. Shuai-hsing. Bk. II, Chap. IV.

32. On Original Nature. Pên-hsing. Bk. III, Chap. IV. 


\section{Lun-hêng}

E. Critique (philosophical, literary and historical).

33. Criticisms on Confucius. Wên K'ung. Bk. IX, Chap. I.

34. Censures on Mencius. T'se Mêng. Bk. X, Chap. II.

35. Strictures on Han Fei Tse. Fei Han. Bk. X, Chap. I.

36. Statements Corrected. Chêng-shuo. Bk. XXVIII, Chap. I.

37. Critical Remarks on Various Books. An-shu. Bk. XXIX, Chap. I.

38. The Equality of the Ages. Ch'i-shih. Bk. XVIII, Chap. III.

39. Exaggerations. Yü-tsêng. Bk. VII, Chap. II.

40. Exaggerations of the Literati. Ju-tsêng. Bk. VIII, Chap. I.

\section{F. Folklore and religion.}

41. Sacrifices to the Departed. Sse-yi. Bk. XXV, Chap. III.

42. Sacrifices. Chi-yi. Bk. XXV, Chap. IV.

43. Criticisms on Noxious Influences. Pien-sui. Bk. XXIV, Chap. III.

44. On Exorcism. Chieh-Ch'u. Bk. XXV, Chap. II.

*

\section{ADDI TI ONAL NOTE}

p1.576 As my readers will have seen from the Preface, I originally proposed to make a selection of Wang Ch'ung's Essays, and to translate only 44, i. e. the philosophical ones, being in my opinion the more important. Some of the leading sinologues having pointed out to me the desirability of having a complete version of Wang Ch'ung's work, I now have changed my mind, and am going to translate the essays left out likewise. They will, later on, be published as 'Lun-Hêng, Part II, Miscellaneous Essays', in contradistinction to the present volume, which I now call 'Lun-Hêng, Part I, Philosophical Essays of Wang Ch'ung'. The whole work will also appear, later on, in the 'Mitteilungen des Seminars für Orientalische Sprachen', probably in 5 parts. The first was already published last year, under the title 'Selected Essays of the Philosopher Wang Ch'ung'. I am very much indebted to Geheimrat SACHAU, Director of the Seminar für Orientalische Sprachen, for kindly having undertaken the publishing of this voluminous work.

Berlin, April 1907

A. FORKE 
A. Forke, Introduction and Appendixes to Wang Ch'ung's

\title{
Lun-hêng
}

\author{
Translation of \\ Wang Ch'ung's Lun-hêng, Part II, miscellaneous essays
}

A. Metaphysical.

1. Coincidences. Ou-hui. Bk. III, Chap. I.

2. Periods of Government. Chih-ch'i. Bk. XVII, Chap. III.

3. Sympathetic Emotions. Kan-lei. Bk. XVIII, Chap. II.

B. Ethical.

4. Success and Luck. Feng-yü. Bk. I, Chap. I.

5. Annoyances and Vexations. Lei-hai. Bk. I, Chap. II.

6. On the Cunning and Artful. Ta-ning. Bk. XI, Chap. III.

7. Weighing of Talents. Ch'êng-ts'ai. Bk. XII, Chap. I.

8. The Valuation of Knowledge. Liang-chih. Bk. XII, Chap. II.

9. Admitting Shortcomings. Hsieh-tuan. Bk. XII, Chap. III.

10. The Display of Energy. Hsiao-li. Bk. XIII, Chap. I.

11. On Intelligence. Pieh-t'ung. Bk. XIII, Chap. II.

12. Apparent Backwardness. Chuang-liu. Bk. XIV, Chap. I.

13. The Real Nature of Knowledge. Shih-chih. Bk. XXVI, Chap. I.

14. A Definition of Worthies. Ting-hsien. Bk. XXVII, Chap. I.

$$
\text { C. Critique. }
$$

15. Fictitious Phenomena. Pien-hsü. Bk. IV, Chap. II.

16. Fictitious Prodigies. Yi-hsü. Bk. V, Chap. I.

17. Fictitious Influences. Kan-hsü. Bk. V, Chap. II.

18. Praise of the Han Dynasty. Hsüan Han. Bk. XIX, Chap. I.

19. Further Remarks on the State. Hui-kuo. Bk. XIX, Chap. II.

20. Ominous Signs Investigated. Yen-fu. Bk. XIX, Chap. III.

21. Necessity of Eulogies. Hsü-sung. Bk. XX, Chap. I.

22. On Literary Work. Shu-chieh. Bk. XXVIII, Chap. II.

23. Falsehoods in Books. Shu-hsü. Bk. IV, Chap. I.

24. Literary Exaggerations. Yi-tsêng. Bk. VIII, Chap. II.

25. Lost Texts. Yi-wên. Bk. XX, Chap. II.

26. The Knowledge of Truth. Chih-shih. Bk. XXVI, Chap. II.

27. On Preeminence. Ch'ao-chi. Bk. XIII, Chap. III.

$$
\text { D. Folklore and Religion. }
$$

28. Thoughts on Omens. Chih-jui. Bk XVII, Chap. I.

29. Auguries Verified. Shih-ying. Bk. XVII, Chap. I.

30. On the Rain Sacrifice. Ming-yü. Bk. XV, Chap. III.

31. Gentle Drums. Shun-ku. Bk. XV, Chap. IV.

32. A Last Word on Dragons. Luan-lung. Bk. XVI, Chap. I.

33. The Tiger Trouble. Tsao-hu. Bk. XVI, Chap. II.

34. Remarks on Insects. Shang-ch'ung. Bk. XVI, Chap. III. 


\section{A. Forke, Introduction and Appendixes to Wang Ch'ung's \\ Lun-hêng}

35. Simplicity of Funerals. Po-tsang. Bk. XXIII, Chap. II.

36. Four Things to be Avoided. Sse-hui. Bk. XXIII, Chap. III.

37. False Charges against Time. Lan-shih. Bk. XXIII, Chap. IV.

38. Slandering of Days. Chi-jih. Bk. XXIV, Chap. I.

39. Questions about the Year Star. Nan-sui. Bk. XXIV, Chap. IV.

40. Criticisms on Certain Theories. Ch'i-shu. Bk. XXV, Chap. I.

$*$

\section{POSTSCRI PT}

This second volume of the Lun-hêng contains the 40 chapters omitted in Vol. I, and referred to in the Additional Note Vol. I, p. 576. The version of Wang Ch'ung's work is now complete, only the sequence of the chapters differ from the original. A Comparative Table of the Chinese Text and the Translation on p. 421 seq. will enable the reader in possession of the original to find each chapter of the translation without difficulty.

As the time of the publication of the Lun-hêng I gave the years 76-84 A. D. (Vol. I, p. 9). A passage on p. 207 of this volume allows of a still narrower limitation. Wang Ch'ung there speaks of the sixth year of the emperor Chang $T i=81 \mathrm{~A}$. D. Consequently the Lun-hêng must have been written after 81 and prior to 84 A. D., viz. in 82 or 83 A. D.

It has been noticed that the Lun-hêng originally contained more than a hundred chapters, whereas we now only possess 84, and of one the mere title. From the present volume we learn the names of three more lost chapters: 'Recognising the Cunning' (p. 48 Note 3), probably in the style of the existing chapter VI 'On the Cunning and Artful', 'How to become a Sage', and 'True Sagehood' (p. 227 Notes 2 and 3), most likely propounding similar views to those contained in chapters XIII 'The Real Nature of Knowledge' and XXVI 'The Knowledge of Truth'.

In the Introduction to Vol. I p. 11, I mentioned a separate edition of the Lun-hêng printed under the Ming dynasty which I had not seen, and of which I was ignorant whether it was still to be found in the book-shops, since my efforts to buy one had been unsuccessful. In the meantime I was fortunate enough to obtain a copy of this edition, which I regard as the best of the 


\section{A. Forke, Introduction and Appendixes to Wang Ch'ung's \\ Lun-hêng}

three current editions, and for this reason have used it as the basis of the second volume of my translation.

This Ming edition referred to by Chang Chih Tung in his bibliography (Ed. B) was prepared by a certain chin-shih, Liu Kuang Tou (Hui Chi, Jên Wei) of Chin-ling (Ch'ang-chou-fu in Kiangsu, together with his friends, all fervent admirers of Wang Ch'ung, most likely in 1626 A. D. Each of them p.2420 has written a preface, so that we have five altogether. Two of these prefaces are dated 1626.

Liu Kuang Tou informs us that in course of time the text of the Lun-hêng had been disfigured by misprints and errata sometimes completely altering the sense. Searching into the libraries and spending much money, his friend Yen Kuang Piao (Tse Yi), a native of Ch'ien-t'ang in Chekiang, at last succeeded in hunting up a good edition of Yang Wên Ch'ang, a chin-shih of the Sung time. This Sung edition was first revised by Liu Kuang Tou, afterwards by Yen Kuang Piao and his friends Ma Yuan (Jên Po) and Shih Chuang ( $K$ 'ang Fu). Yen Kuang Piao finally fixed the text and edited it at his own expense. His preface dates from his 'Hall of Frozen Perfume', whence this edition is designated as [] on the title-page.

My copy seems to be the original edition, and a red stamp on the titlepage to contain the name of Yen (Kuang Piao). Another red impression states that the blocks of this edition are kept in the office of the owner, and that any unauthorised reprint will be pursued to a thousand Li's distance [].

I have denoted the edition of the Han Wei ts'ung-shu as Ed. A, the Ming edition as $E d . B$, and the edition contained in the Tse shu-po-chia as Ed. C. In my notes to Vol. II, I have frequently pointed out differences in the three editions, which after all are not very great. In regard to correctness of the text Ed. $B$ ranks first, then follows $E d$. $C$, and Ed. A comes last. Whenever there is any divergence, $E d$. $A$ and $C$ mostly agree, but $E d$. $C$ avoids the apparent misprints of which $E d$. $A$ has a great many. This remark refers to my own edition of the Han Wei ts'ung-shu which is not very good. In the newly acquired copy of the Royal Library in Berlin many mistakes have been corrected. Ed. $C$ would seem to be a revised reprint of $E d$. $A$. Ed. $B$ is much more independent, and in most cases gives the best reading. 


\section{A. Forke, Introduction and Appendixes to Wang Ch'ung's Lun-hêng}

Wang Ch'ung is very fond of quoting the Classics and other old authors, notably the Analects, the Shuking, and the Shi-chi. Since not only his reading often differs from the now authorised text, but his explanations also not seldom disagree with those of modern commentators, I thought it worth while preparing a list of all the quotations I was able to trace, which may be useful for a critique of the old texts. 


\section{A. Forke, Introduction and Appendixes to Wang Ch'ung's \\ Lun-hêng}

\section{QUOTATIONS}

@

The numbers in brackets refer to the pages of the translation. I denotes Vol. I, II is Vol. II. L. means Legge's translation of the Classics and of the Yiking and the Liki in the Sacred Books viz. Vols. XVI, XXVII, XXVIII.

Latin figures serve to designate the books of a work and Arabic, the page except in the Analects where they denote the number of the chapter.

\section{Analects}

I, 10 (II, 282).

II, 2 (II, 280) ; II, 4 (II, 126) ; II, 4 (II, 292) ; II, 5 (I, 394) ; II, 6 (I, 394) ; II, 9 (I, $398)$; II, 19 (I, 386) ; II, 23 (II, 121) ; II, 23, 2 (I, 455).

III, 1 (I, 395) ; III, 5 (I, 407) ; III, 6 (I, 395) ; III, 6 (II, 24) ; III, 14 (I, 474) ; III, 15 (I, 434); III, 15 (II, 284).

IV, 5 (I, 389) ; IV, 5 (I, 395) ; IV, 7 (I, 402).

$\mathrm{V}, 1(\mathrm{I}, 397) ; \mathrm{V}, 4(\mathrm{I}, 427) ; \mathrm{V}, 4(\mathrm{II}, 55) ; \mathrm{V}, 8(\mathrm{I}, 398) ; \mathrm{V}, 9(\mathrm{I}, 399) ; \mathrm{V}, 9$ (I, $400) ; \mathrm{V}, 18$ (I, 401) ; V, 18 (II, 105) ; V, 27 (II, 255).

VI, 2 (I, 402) ; VI, 5 (I, 398) ; VI, 8 (I, 165) ; VI, 9 (I, 398); VI, 15 (II, 416); VI, 17 $(\mathrm{I}, 152) ; \mathrm{VI}, 21$ (II, 219) ; VI, 26 (I, 403).

VII, 9 (II, 19) ; VII, 15 (I, 416) ; VII, 34 (II, 182).

VIII, 3 (II, 379) ; VIII, 7 (II, 87) ; VIII, 10 (I, 399) ; VIII, 15 (I, 467); VIII, 18 (I, 98) ; VIII, 18 (I, 482); VIII, 19, (I, 98); VIII, 19 (I, 478); VIII, 19 (II, 222) ; VIII, 19 (II, 267); VIII, 20 (II, 273); VIII, 20 (II, 278).

IX, 5 (II, 302) ; IX, 6 (I, 102) ; IX, 6 (II, 292) ; IX, 8 (I, 405) ; IX, 10 (II, 98) ; IX, 10 (II, 201) ; IX, 11 (II, 24) ; IX, 13 (I, 406) ; IX, 14 (II, 286) ; IX, 22 (II, 121).

$X, 8,10(\mathrm{I}, 523) ; \mathrm{X}, 16(\mathrm{I}, 295) ; \mathrm{X}, 18$ (II, 138).

XI, 4 (II, 287) ; XI, 7 (I, 411) ; X1, 8 (I, 409) ; XI, 8 (II, 2) ; XI, 9 (I, 411) ; XI, 16 (II, 345) ; XI, 18 (I, 408) ; XI, 22 (II, 283) ; XI, 24 (I, 408) ; XI, 24 (I, 449) ; XI, 24 (II, 268) ; XI, 25, 7 (I, 520, 11, 335).

XII, 5 (I, 136) ; XII, 7 (I, 412) ; XII, 12 (II, 195) ; XII, 18 (I, 403).

XIII, 3 (I, 407) ; XIII, 9 (I, 413) ; XIII, 24 (I1, 130).

XIV, 14 (I, 500) ; XIV, 14 (II, 281) ; XIV, 18 (II, 26) ; XIV, 26 (I, 414) ; XIV, 38 (II, 7) ; XIV, 38 (II, 10).

$X V, 8(I, 412) ; X V, 24(I, 441) ; X V, 30$ (II, 128).

XVI, 9 (II, 120) ; XVI, 10 (II, 284).

XVII, 1 (I, 417) ; XVII, 1 (II, 283) ; XVII, 2-3 (I, 387) ; XVII, 5 (I, 417) ; XVII, 6 (I, 283) ; XVII, 7 (I, 415) ; XVII, 12 (I, 445) ; XVII, 19 (I, 184) ; XVII, 22 (II, 104).

XIX, 19 (I, 288) ; XIX, 20 (I, 478) ; XIX, 20 (I, 485) ; XIX, 20 (II, 271) ; XIX, 22 (II, 125); XIX, 23 (II, 101). 


\section{A. Forke, Introduction and Appendixes to Wang Ch'ung's \\ Lun-hêng}

\section{Shuking}

L. I : p. 15 (II, 220). p. 17 (II, 263). p. 24 (II, 188). p. 25 (I, 315). p. 26 (I, 459). p. 31 (I, 459). p. 32 (II, 19). p. 32 (I, 128). p. 33 (I, 516). p. 47 (II, 257). p. 48 (II, 80). p. 49 (II, 181). p. 51 (I, 316). p. 59 (II, 46). p. 70 (II, 147). p. 70 (II, 320). p. 73 (II, 266). p. 80 (II, 71). p. 84 (I, 404). p. 85 (I, 490). p. 88 (I, 363). p. 108 (II, 247). p. 113 (II, 250). p. 127 (I, 378). p. 271 (II, 268).

L. II : p. 315 (I, 484). p. 330 (I, 374). p. 340 (I, 282). p. 340 (I, 302). p. 342 (I, 277). p. 351 (I, 205). p. 359 (II, 17). p. 359 (II, 21). p. 385 (I, 134). p. 399 (I, 121). p. 428 (II, 405). p. 455 (I, 98). p. 455 (I, 481). p. 464 (I, 504). p. 466 (I, 502). p. 468 (I, 482). p. 469 (II, 233). p. 471 (I, 123). p. 477 (II, 21). p. 518 (II, 333). p. 592 (I, 114). p. 593 (I, 123). p. 629 (I, 418).

\section{Shi-chi}

Chap. 3 p. 1 (I, 464) ; p. 10r. (II, 29) ; p. 11 (I, 488).

Chap. 4 p. 1 (I, 464) ; p. 39 (I, 506).

Chap. 6 p. 6 (I, 311) ; p. 18 (I, 507) ; p. 21v. (I, 491) ; p. 24 (I, 231) ; p. 24 (I, 492) ; p. 25v. (I, 492) ; p. 26v. (II, 116).

Chap. 8 p. 1 v. (I, 178); p. 2 (I, 305); p.5 (I, 234); p. 11v. (I, 530); p. 35v. (I, 148).

Chap. 24 p. 39 (I, 222).

Chap. 28 p. 20 (I, 508); p. 21 (I, 344).

Chap. 31 p. 9v. (I, 523).

Chap. 33 p. 3v. (II, 233).

Chap. 40 p. 11 (I, 177).

Chap. 41 p. 6v. (I, 310) ; p. 7r. (II, 144).

Chap. 43 p. 7 (I, 225) ; p. 11 (I, 226) ; p. 12 (I, 230) ; p. 19 (I, 226).

Chap. 47 p. 12v. (I, 312).

Chap. 55 p. 1 v. $(\mathrm{I}, 236)$.

Chap. 57 p. 6v. (I, 309).

Chap. 61 p. 3v. (I, 168).

Chap. 63 p. 2v. (I, 358).

Chap. 69 p. 12v. (II, 269).

Chap. 70 p. 2v. (II, 52).

Chap. 75 p. 2r (II, 384); p. 2v. (I, 161).

Chap. 83 p. 9 v. (II, 175).

Chap. 84 p. 6r. (II, 40).

Chap. 86 end (II, 177).

Chap. 88 p. 5 (I, 167).

Chap. 91 p. 1 (I, 308).

Chap. 92 p. 16 r. (II, 144).

Chap. 109 p. 6 (I, 169). 


\section{A. Forke, Introduction and Appendixes to Wang Ch'ung's \\ Lun-hêng}

Chap. 111 p. 1v. (I, 308).

Chap. 123 p. 9 v. (I, 174).

Chap. 129 p. 3v. (II, 327).

\section{Ch`un-ch`iu}

Huan, 17th year $(I, 458)$.

Chuang, 2nd year (II, 254).

Chuang, 7th year (I, 274). 25th year (II, 339).

Hsi, 16th year (I, 276).

\section{Tso-chuan}

Huan, 5th year (II, 336).

Chuang, 8th year ( $I, 245)$.

Hsi, 10th year (I, 204). 22nd year (II, 119). 28th year (I, 189). 29th year (II, 123).

Wên, 1st year (I, 207). 18th year ( $I, 243)$.

Hsüan, 3rd year (I, 505). 15th year (I, 211).

Hsiang, 19th year (I, 206). 21st year (I, 302). 21st year (I, 351). 31st year (II, 74).

Chao, 4th year (I, 227). 5th year (I, 187). 7th year (I, 209). 7th year (I, 214). 8th year $(I, 237)$. 13th year $(I, 177)$. 26th year (II, 154). 29th year $(I, 356)$.

\section{Mencius}

Bk. I, Pt. I, 1 (I, 418). Pt. II, 16 (I, 422). Pt. II, 16 (I, 432).

Bk. II, Pt. 1, 2 (I, 421). Pt. I, 2 (19) (II, 293). Pt. I, 2 (20) (II, 293). Pt. I, 2 (22) (II, 294). Pt. II, 3 (I, 420). Pt. II, 8 (I, 420). Pt. II, 9 (II, 288). Pt. II, 10 (I, 419). Pt. II, 12 (I, 422). Pt. II, 13 (I, 423).

Bk. III, Pt. I, 1 (I, 467). Pt. II, 4 (I, 420). Pt. II, 4 (I, 426). Pt. II, 9 (1) (I, 85). Pt. II, $10(\mathrm{I}, 427)$.

Bk. IV, Pt. 1, 15 (I, 385). Pt. II, 21 (I, 457).

Bk. VI, Pt. I, 2 (I, 386).

Bk. VII, Pt. I, 2 (I, 431). Pt. 1, 3 (I, 139). Pt. II, 3 (I, 485). Pt. II, 15 (II, 294). Pt. II, 37 (II, 147).

\section{Huai Nan Tse}

II, 4r. (I, 100).

III, 2 (I, 279). 2r. (II, 350).

IV, VI, 1v. (II, 172).

VI, 1v. (II, 173). 2r. (II, 178). 


\section{A. Forke, Introduction and Appendixes to Wang Ch'ung's \\ Lun-hêng}

VII, 8v. (II, 169).

VIII, 5r. (II, 167). 5r. (II, 184). 5r. (II, 186). 6v. (II, 19).

$X I, 5 r .(I, 100)$.

XII, 4r. (II, 95). 11 v. (I, 328). 11 v. (II, 153).

XII, 22r. (II, 160).

XIII, 9r. (II, 233).

XIII, 14 r. (II, 126).

XVI, 1 v. (II, 181). 1 v. (II, 190). 13 (I, 415).

XVII. 25V. (I, 374).

XVIII, 6 (I, 159). 17r. (II, 147). 18 v. (II, 376). 19r. (I, 69).

$X X, 2(I, 96)$.

\section{Liki}

L. I : p. 80 (II, 386). p. 84 (I, 325). p. 123 (I, 197). p. 123 (II, 284). p. 128 (II, 23). p. 135 (I, 164). p. 136 (I, 411). p. 136 (I, 501). p. 181 (I, 186). p. 201 (II, 329). p. 208 (I, 522). p. 244 (II, 315). p. 260 (I, 141). p. 310 (I, 141). p. 344 (I, 316).

L. II : p. 5 (I, 296). p. 5 (II, 347). p. 90 (II, 133). p. 201 (I, 517). p. 206 (I, 519). p. 208 (I, 519). p. 208 (I, 522).

\section{Shiking}

Pt. I, Bk. IV, Ode IX, 2 (I, 374); (I, 387).

Pt. II, Bk. III, Ode X, 2 (II, 264). Bk. V, Ode III, 2 (II, 244). Bk. V, Ode IX, 6 (II, 323). Bk. VII, Ode V (I, 303); (II, 367). Bk. VIII, Ode VIII (I, 277).

Pt. III, Bk. I, Ode I (II, 266). Bk. I, Ode II (II, 154). Bk. I, Ode VII, 1 (I, 134). Bk. 11, Ode I, 2 (I, 318). Bk. II, Ode V, 2 (II, 264). Bk. II, Ode VIII (I, 369). Bk. III, Ode III (II, 265). Bk. III, Ode IV, 3 (II, 10).

Pt. IV, Bk. III, Ode II (I, 330).

\section{Yiking}

1st diagram (I, 128 ; I, 134 ; I, 283 ; I, 356 ; I, 418 ; I, 529).

5th diagram, L. p. 67 (I, 418).

22nd diagram, L. p. 231 (II, 275).

30th diagram, L. p. 237 (I, 267).

49th diagram, L. p. 168 (II, 275).

55th diagram, L. p. 186 (II, 266). L. p. 336 (I, 275).

63rd diagram, L. p. 205 (II, 201). L. p. 206 (I, 514).

Chi-t'se II, L. p. 383 (I, 98). L. p. 385 (I, 473).

Chap. I, p. 7v. (Chin. text) (II, 183). 
A. Forke, Introduction and Appendixes to Wang Ch'ung's

Lun-hêng

\section{Han Fei Tse}

XIII, 5 (I, 436). 5 (I, 440). 5v. (I, 433).

XVI, 1 (I, 442). 5 (I, 443).

XIX, 4 (I, 445)

\section{Lieh Tse}

IV, 4V. (II, 147).

V, 5 v. (I, 250).

VIII, 2 (I, 96). 6r. (II, 95). 6v. (I, 159).

\section{Chung-yung}

Chap. XV (I, 153)

Chap. XVIII, 3 (II, 23)

\section{Kung Yang}

Chuang, 7th year (I, 274).

Hsi, 31st year (I, 277).

\section{Erh-ya}

Chap. 9 p. 6 (II, 324).

\section{K'ung Tse chia-yü}

4 p. 8 v. (II, 308).

\section{Shan-hai-king}

Chap. 9 p. 1v. (I, 271).

\section{Lü-shi ch‘un-ch‘iu}

IV, 2v. (II, 258).

\section{Ch'ien Han-shu}

Chap. 8 p. 21v. (II, 197).

Chap. 64a, p. 13v. (II, 135).

Chap. 68 p. 21 r. (II, 354). 
A. Forke, Introduction and Appendixes to Wang Ch'ung's

\section{Lun-hêng}

\section{APPENDIX I}

\section{The Theory of the Five Elements and the Classifications based thereon}

\section{A Sketch of Chinese Natural Philosophy}

p2.431 The theory of the Five Elements is no doubt of Chinese origin and its existence in ancient times proved by many old documents. We read in one of the first books of the Shuking, the 'Counsels of the Great Yü' :

« Yü said, Well ! may Your Majesty think of it. Virtue implies good government, and government consists in nourishing the people. Water, fire, metal, wood, earth, and grain must be attended to. The rectification of virtue, the supply of all useful things, and ample provision for the necessaries of life must be well balanced. These nine achievements succeed each other, and the nine successive steps are praised in songs. - Caution the people with kindness, govern them with majesty, and incite them with the nine songs, in order that there may be nothing amiss.

The emperor ${ }^{1}$ said, 'Yes, the earth is undisturbed now, heaven is in perfect order, and the six treasuries and three affairs properly managed. Ten thousand generations may perpetually rely on them. All this is your doing'. (Legge, Classics Vol. III, Part I, p. 55 seq.) [Couvreur]

What does it mean that the Five Elements : water, fire, metal, wood, and earth must be controlled by the Emperor? How can he exercise any power on nature ? - By regulating his administration on the natural sequence of the elements, doing only those things which are in harmony with the element ruling for the time being. Natural phenomena are thus affected by the actions of the son of Heaven, being either disturbed or kept in their regular course. The Liki will give us the necessary details.

\footnotetext{
${ }^{1}$ Shun, thus apostrophed by Yü.
} 


\section{A. Forke, Introduction and Appendixes to Wang Ch'ung's \\ Lun-hêng}

The elements are here enumerated in the series in which they overcome

or destroy one another, for which the terms 勝 or 克 are used. This p2.432 part of the theory of the Five Elements seems to have been known to the compilers of the Shuking.

The above passage is quoted and explained by the Tso-chuan, Duke Wên 7th year, and its genuineness thus firmly established. The corresponding passage of the Tso-chuan reads thus :

«The book of Hsia ${ }^{1}$ says, 'Caution the people with kindness, govern them with majesty, and incite them with the nine songs, that there may be nothing amiss'. The virtues of the nine achievements may be sung, and are called the nine songs. The six treasuries and the three affairs are called the nine achievements. Water, fire, metal, wood, earth, and grain are called the six treasuries. The rectification of virtue, the supply of all useful things, and ample provision for the necessaries of life are called the three affairs. (Cf. Legge, Classics Vol. V, Part I, p. 247.) [Couvreur]

In another book of the Hsia dynasty, entitled 'the Speech at Kan', the following words are attributed to the Emperor $C^{\prime}{ }^{\prime} i$, who is supposed to have spoken them in 2194 B. C. :

«The Lord of $\mathrm{Hu}$ offers violence and insult to the Five Elements, and neglects and discards the three commencements (of the seasons). Therefore Heaven employs me to destroy and cancel his appointment. Now I merely reverently mete out the punishment of Heaven. (Legge, Classics Vol. III, Part I, p. 153.) [Couvreur]

Legge rightly observes that the crime of the Lord of $\mathrm{Hu}$ is stated in a somewhat obscure and mystical language. The Five Elements are not to be taken in the simple physical sense, for then they could not be outraged by a sovereign, but are metaphysical terms, equivalent almost to the four seasons, as one commentator points out. The seasons are nothing else than the result of the revolutions of the Five Elements, and a ruler commits a crime, if for his

\footnotetext{
1 The 'Counsels of the Great Yü', Yü being the founder of the Hsia dynasty.
} 


\section{A. Forke, Introduction and Appendixes to Wang Ch'ung's \\ Lun-hêng}

administrative acts he does not choose the proper time, neglecting the seasons. At all events there is some theory at the bottom of the very concise expression.

Another criminal of this sort is introduced to us in the chapter Hung-fan (The Great Plan) of the Shuking, where the Viscount of Chi says :

- I have heard that of old $K^{\prime}$ 'un by damming up the Great Flood threw the Five Elements into confusion. God was highly incensed at p2.433 him, and did not grant him the Great Plan with the nine divisions'. (Legge, Classics Vol. III, Part II, p. 323.) [Couvreur]

I suppose that the imaginary guilt of $K^{\prime} u n$ did not so much consist in his illtreating the element water as in not observing the propitious time for his draining work, thereby disturbing the Five Elements $i$. e., the Five Seasons and thus bringing down calamities upon his people.

Further on the Hung-fan informs us of the nature of the Five Elements, the fullest description to be found in the Shuking :

«First the Five Elements : the first is termed water; the second, fire ; the third wood; the fourth metal ; the fifth, earth. Water is described as soaking and descending; fire as blazing and rising ; wood as crooked and straight; metal as yielding and changing, whereas the nature of earth appears from sowing and reaping. That which is soaking and descending becomes salt; that which is blazing and rising becomes bitter; that which is crooked and straight becomes sour; that which is yielding and changing becomes acrid; and the produce of sowing and reaping becomes sweet. (Legge, Classics Vol. III, Part II, p. 325.) [Couvreur]

The sequence of the Five Elements is different from that in the Hsia-shu insomuch as here wood precedes metal. It is the sequence in which originally the elements were created. This at least is the opinion of Chu Hsi, which we shall examine later on. The nature of the Five Elements is described, and another category, that of the Five Tastes : salt, bitter, sour, acrid, and sweet connected therewith $i$. e., we have here the first classification based on the five elements. From this one to the others there is only one step. It is just 


\section{A. Forke, Introduction and Appendixes to Wang Ch'ung's \\ Lun-hêng}

this book of the Shuking which shows us the great partiality of the ancient Chinese to numerical categories and classifications. We find already the 五事 Five Businesses : demeanour, speech, seeing, hearing, and thinking, immediately following upon the five elements, and further on the $\boldsymbol{\text { 㑕 }}$ 徽 Five Manifestations, or五氣 Five Atmospheric Influences as they are now called, viz. 雨暘燠寒風 rain, sunshine, heat, cold, and wind (Legge, loc. cit. p. 339) which subsequently were combined with the Five Elements. The love of symbolism, and the tendency of discovering analogies between natural and moral phenomena appears already in what the Hung-fan has to say on the Five Manifestations : $\mathrm{p} 2.434$

«There are the auspicious manifestations: self-possession is related to seasonable rain ; orderliness, to seasonable sunshine; judiciousness, to seasonable heat ; discretion, to seasonable cold ; and sageness, to seasonable wind. There are likewise the evil manifestations : excitement is related to incessant rain ; confusion, to incessant sunshine ; fickleness, to incessant heat ; impetuosity, to incessant cold ; and dullness, to incessant wind.

It is said that the emperor pays attention to the year; his ministers and high officers, to the months, and the petty officials, to the single days. When, during a year, a month, or a day, the seasonableness does not change, then all the crops ripen, the administration is enlightened, excellent persons become illustrious, and the people enjoy peace and happiness. But, when during a day, a month, or a year, the seasonableness changes, then the crops do not ripen, the administration is beclouded and unenlightened, excellent persons remain in obscurity, and the people do not enjoy quietude. (Legge, loc. cit. p. 340 seq.) [Couvreur, p. 207]

Already at the beginning of the Chou dynasty, in the 11 th century B. C., the Chinese had discovered some resemblance between heaven and earth, and the four seasons with the six ministries, which appears from the names of these departments recorded in the Chou-li. There is the prime minister, the chief of the Civil Office or Officer of Heaven; the minister of the interior and 


\section{A. Forke, Introduction and Appendixes to Wang Ch'ung's \\ Lun-hêng}

of revenue or Officer of Earth ; the minister of ceremonies or Officer of Spring; the minister of war or Officer of Summer; the minister of punishments or Officer of Autumn; and the minister of works or Officer of Winter.

We learn from the same source that the vice-president of the Board of Ceremonies

« erected altars to the Five Emperors in the four suburbs : (Cf. Le Tcheou-li par E. Biot Vol. I, p. 421, Vol. I, p.441 and Vol II, p. 324).

These Five Emperors were five old rulers subsequently deified and venerated as the deities of the Five Points.

These are two more corner stones added to the system of the Five Elements. We have no literary evidence to show that this was done already at the commencement of the Chou epoch, although there is nothing p2.435 against such a supposition. At all events this step had been taken some centuries later, for in the Tso-chuan we see the theory pretty well evolved from the nucleus observed in the older sources.

We read under Chao-kung 29th year :

«Therefore there were the officers of the Five Elements, who accordingly were called the Five Officers. They, in fact, received their family and clan names, and were appointed high dignitaries. As divine spirits they were sacrificed to, and honoured, and venerated at the altars of the Spirits of the Land and Grain and the Five Sacrifices. The ruler of wood was called Kou Mang, that of fire Chu Yung, of metal Ju Shou, of water Hsüan Ming, and of earth Hou Tu. . . . . Viscount Hsien inquired of which families were these Five Officers partaking of the oblations to the Spirits of the Land and Grain and the Five Sacrifices. Tsai Mê replied :

- At the tune of Shao Hao there were four men : Chung, Kai, Hsiu, and $\mathrm{Hsi}$, who were able to regulate metal, wood, and water. Chung was made Kou Mang, Kai was made Ju Shou, and Hsiu and Hsi, Hsüan Ming. They never were remiss in discharging their duties 


\section{A. Forke, Introduction and Appendixes to Wang Ch'ung's \\ Lun-hêng}

and in assisting Ch'iung Sang (Shao Hao). For these are the Three Sacrifices. Chuan Hsü had a son named Li, who become Chu Yung ; Kung Kung had a son named Kou Lung, who became Hou Tu. For these are the Two Sacrifices. Hou Tu became Spirit of the Land and Grain and director of the fields. [Couvreur]

Here we have five sons of old legendary rulers raised to the dignity of spirits of the Five Elements after their deaths. They partake of the Five Sacrifices offered to the Five Emperors in the four suburbs and the centre $i$. e., they are assistant deities of the Five Points. That they were, moreover, regarded as genii of the seasons appears from their names, for Kou Mang 'Curling fronds and spikelets' evidently points to spring, and Ju Shou 'Sprouts gathered' designates autumn. Chu Yung referring to heat may well denote summer, and Hsüan Ming 'Dark and obscure', winter. Thus we have the Five Elements and their deities connected with the Five Points and the Five Seasons. See also Vol. I, p. 518 and 576. The Five Sacrifices of Wang Ch'ung Vol. I, p. 517 are others than those of the Chou-li, here referred to.

But the most important testiinony of the Tso-chuan is to be found in the following passage, Duke Chao 25th year :

«Chien Tse said,

- I venture to ask what is meant by propriety ?

Tse Tai Shu replied,

- I heard the former great officer Tse Chan say : Propriety is the principle of Heaven, the rule of Earth, and the basis of human conduct. This principle of Heaven and Earth is imitated by the people conforming to the luminaries of Heaven and agreeing with the nature of Earth. The Six Fluids are produced and the Five Elements made use of. The fluids become the Five Tastes, manifest themselves as the Five Colours, and appear as the Five Sounds. [Couvreur]

p2.436 And farther on we read :

«People feel love and hatred, pleasure and anger, sorrow and joy, which feelings are produced from the Six Fluids. Therefore one 
A. Forke, Introduction and Appendixes to Wang Ch'ung's

\section{Lun-hêng}

carefully imitates relations and analogies, in order to regulate these Six Impulses'.'

By the Six Fluids or atmospherical influences are understood 陰陽風雨晦明 the Yin principle, the Yang principle, wind, rain, darkness, and light, a classification somewhat different from that of the Five Fluids of the Shuking.

In the above quoted passage the Five Elements are combined with the Five Tastes, the Five Colours, and the Five Sounds on the one side, and with the Six Fluids and the Six Impulses on the other. After all, there are but five entities which appear to us under different forms, either as substances or as atmospherical fluids, or as tastes, colours or sounds. And even human feelings are nothing else but manifestations of these fluids.

Elsewhere the Tso-chuan informs us that

« the former kings constituted the five tastes and harmonized the five sounds. It is by these that they made their minds equable and regulated their administration. Sounds are nearly related to tastes. (Tso-chuan, Duke Chao 20th year.) [Couvreur, p. 326-327]

That the antagonism of the elements was well known at the time of the Tso-chuan we infer from the following passages:

«Water overcomes fire (Duke Ai, 9th year),

and

« Fire overcomes metal (Duke Chao, 31st year).

The meeting of two opposed elements is compared to a marriage, and the stronger element subduing the weaker, called the husband, the weaker being looked upon as the wife. 'Water is the husband of fire' (Duke Chao, 17th year), and 'fire is the wife of water' (Duke Chao, 9th year).

Finally the Five Elements are connected with the cyclical signs of the Ten Stems and the Twelve Branches. A disaster is predicted on a Ping-tse or a Jên-wu day, because on these there is a meeting of water and fire, ping corresponding to fire, and tse to water, jên to water, and wu to fire. p2.437 Since these cyclical signs serve to denote the points of the compass, the Five Elements must be referred to them also. So we read that 'tse is the position 


\section{A. Forke, Introduction and Appendixes to Wang Ch'ung's \\ Lun-hêng}

of water ${ }^{1}$ (Duke Ai, 9th year) $i$. e., that water is placed in the North.

The Tso-chuan states that the Five Elements manifest themselves as the Five Colours, but does not assign the different colours to the various elements. This is done in the Chi-chung chou-shu, a collection of ancient texts excluded by Confucius from the Shuking, and consequently prior in time to the 6 th century B. C. (Cf. Chavannes, Mem. Hist. Vol. V, p. 457). There we read :

«Among the Five Elements the first, the black one, is water ; the second, the red one, is fire ; the third, the green one, is wood; the fourth, the white one, is metal ; and the fifth, the yellow one, is earth.

Resuming the adduced old testimonies, we may assert that, at the time of Confucius and before, the theory of the Five Elements was known and developed in all its chief features. The elements are roughly described and conceived as partly physical, partly metaphysical entities. They vanquish one another in a certain order already given in the Shuking. The weaker element in such a contest is termed the wife, the stronger, the husband. The atmospherical fluids, closely connected with the elements, affect mankind, in so far as they are believed to produce impulses and sensations, and, conversely, human actions may influence these fluids. The sovereign especially regulates the elements by the virtue displayed in his administration. There are five officers or deities presiding over the elements and, at the same time, venerated as genii of the seasons, in the five directions, together with the Five Emperors, ruling over the five points of the compass. Thus we have a link between the elements, the seasons, and the five directions. Moreover, the fluids and the elements manifest themselves under the form of the five tastes, the five colours, and the five sounds. Tastes and colours are enumerated and assigned to the respective elements, and we may assume that the same was done with the five sounds, although we have no literary evidence to prove it. By their combination with the signs of the denary and duodenary cycles, the five elements were again located in those points of the compass to which these signs correspond.

In the Appendix to Couvreur's Dictionary there is a table of the Five 


\section{A. Forke, Introduction and Appendixes to Wang Ch'ung's \\ Lun-hêng}

Elements and their corresponding categories, altogether 12 columns. Of these we have so far traced nine, only the five heavenly Emperors, the five planets, and the five viscera have not yet been mentioned. But these also were referred to the elements in the Chou dynasty, as we shall see from the Liki and other works.

p2.438 A short sketch of a natural philosophy is given in the chapter Li-yün of the Liki (Legge, Sacred Books Vol. XXVII p. 380 seq.) [Couvreur], in which the Five Elements play a part. Man is said to be the product of the forces of Heaven and Earth, by the interaction of the Yin and the Yang, the union of the animal and intelligent spirits, and the finest matter of the Five Elements. This, of course, would account for the many relations existing between the elements and the human body as well as human actions. Moreover, the Five Elements are distributed over the Four Seasons. They are in constant movement and alternately exhaust one another. Each of them becomes in its turn the fundamental one just like the Four Seasons and the Twelve Months. It is not expressly stated that the five sounds, the five tastes, and the five colours are identical with the five elements, but they are mentioned in close connexion with the elements and declared to undergo similar regular revolutions by which each sound, taste, and colour for a certain time becomes the principal one. Throughout the whole treatise we notice the intimate relation of human life to all the forces of nature, the elements included.

The chapter Li-yün is by some attributed to Tse Yu, a disciple of Confucius or to his disciples and regarded as one of the most valuable parts of the Liki. I do not share Legge's view that the ideas about elements, numbers, colours, \&c. are Taoistic admixtures to the common-sense of C'onfucianism, for we have met them all in the Confucian Classics. (Cf. Legge's Liki, Introduction p. 24.)

How the elements and their correlates were distributed over the twelve months we learn from another book of the Liki, the Yüeh-ling (Legge, eod. p. 249 seq.) [Couvreur] embodying the fullest scheme of this theory in classical literature. It is a sort of a calendar clearly showing us how much the doctrine of the five elements was interwoven with the life of the ancient Chinese. For each of the four seasons it is stated that the Grand Annalist informed the Son 


\section{A. Forke, Introduction and Appendixes to Wang Ch'ung's \\ Lun-hêng}

of Heaven of the day on which the season began and of the element ruling over the three months composing the season. The element earth alone had no proper season.

About the first month of spring we learn that its days are chia and $y i{ }^{1}$, its divine ruler is T'ai Hao, and the attending spirit Kou Mang. Its creatures are the scaly, its musical note is chio, its number 82 , its taste is sour, p2.439 its smell is rank. Its sacrifice is that at the inner door ${ }^{3}$, and for this the spleen of the victim is essential. The east winds resolve the cold. The Son of Heaven occupies the apartment on the left of the Ch'ing-yang Fane ${ }^{4}$, and rides in a carriage drawn by green dragon horses, carrying a green flag and wearing green robes and pieces of green jade. His food consists in wheat and mutton. At the head of his ministers and the feudal princes, the emperor meets the spring in the eastern suburb. The inspectors of the fields are ordered to reside in the lands having an eastward exposure. They instruct the people, and see that all the necessary measures for cultivating the fields be taken. Prohibitions are issued against cutting down trees and the killing of young animals, birds, or insects. No fortifications are to be erected, no warlike operations to be undertaken, for they would be sure to be followed by the calamities from Heaven. I refrain from quoting all the other prescriptions and defences and would only draw attention to the characteristical last paragraph of this section which has its counterpart in all the other months :

«If in the first month of spring the governmental proceedings proper to summer were carried out, the rain would fall

\footnotetext{
1 The two first of the ten cyclical signs.

2 This number is said to refer to the vernal element wood. The Five Elements are counted in the sequence of their creation (see above p. 433): water, fire, wood, metal, earth. Now the last only is given its natural number 5 . All the other elements have their number in the series plus 5 .

3 One of the five sacrifices of the house. Cf. Vol. I, p. 510. The correspondence of these offerings with the seasons and elements is obvious. The door symbolises the opening of the year and the display of the energies of nature. The outer door, or the gate, is the counterpart of the inner door and therefore connected with the autumn sacrifice. The sacrifice to the earth goes well with fire, that to the inner court with earth or the centre, and that of the well with water. Our text of the Liki reads 'path' for 'well'. (Cf. Legge, loc. cit., p ; 297, Note 1). I follow Wang Ch'ung, I, p. 510.

4 The eastern part of the Hall of Distinction, where the emperor went on the first day of the month. Ch'ing-yang means 'green and bright'.
} 


\section{A. Forke, Introduction and Appendixes to Wang Ch'ung's \\ Lun-hêng}

unseasonably, plants and trees would decay prematurely, and the states would be kept in continual fear. If the proceedings proper to autumn were carried out, there would be great pestilence among the people; boisterous winds would work their violence; rain would descend in torrents; orach, fescue, darnel, and southernwood would grow up together. If the proceedings proper to winter were carried out, pools of water would produce their destructive effects, snow and frost would prove very injurious, and the first sown seeds would not enter the ground.

In a similar way the other months are described. We abstract therefrom the following Table (pp. 440 and 441).

The Yüeh-ling is now universally ascribed to Lü Pu Wei of the 3rd century B. C. (Legge, Liki, Indroduction p. 20), but there is no reason to suppose that it was invented by him and that it is not a calendar of the Chou period, for its contents accords very well with other sources and was, at all events, regarded as a genuine record of old customs by the compilers of the Liki. p2.440

\section{Table of the Five elements, the Four seasons and other correspondencies according to the Liki.}

\begin{tabular}{l|l|l|l|l|l|} 
Five Elements & wood & fire & earth & metal & water \\
Four Seasons & spring & summer & & autumn & winter \\
Five Emperors & T'ai Hao & Yen Ti & Huang Ti & Shao Hao & Chuan Hsü \\
Five Spirits & Kou Mang & Chu Yung & Hou Tu & Ju Shou & Hsüan Ming \\
Five Sacrifices & inner door & hearth & inner court & outer door & well \\
Five Animals & sheep & fowl & ox & dog & pig \\
Five Grains 1 & wheat & beans & panicled millet & hemp & millet \\
Five Intestines & spleen & lungs & heart & liver & kidneys \\
Five Numbers & 8 & 7 & 5 & 9 & 6 \\
Ten Stems & chia yi & ping ting & wu chi & kêng hsin & jên kuei \\
Five Colours & green & red & yellow & white & black \\
Five Sounds & chio & chih & kung & shang & yü \\
Five Tastes & sour & bitter & sweet & acrid & salt \\
Five Smells & goatish & burning & fragrant & rank & rotten \\
Five Points & east & south & centre & west & north \\
Five Creatures & scaly & feathered & naked & hairy & shell-covered
\end{tabular}

\footnotetext{
1 The correspondencies of the Five Grains do not quite agree with those given in Mayers' Manual p. 316 insofar as he combines beans with water, and millet with fire. His translation of [] by rice instead of 'panicled millet', which I have followed in Vol. I, p. 381, is not quite correct. It is also better to render [] by 'spleen', for which in Vol. I, p. 105 I have written 'stomaCh' as Mayers does.
} 


\section{A. Forke, Introduction and Appendixes to Wang Ch'ung's}

\section{Lun-hêng}

The literary evidence of ancient texts collected above is more than sufficient, I trust, to establish the fact that the theory of the Five Elements is of Chinese origin. This has been contested by no less an authority than Ed. Chavannes, who is of opinion that the Chinese have borrowed it from the Turks (cf. Ed. Chavannes, 'Le cycle turc des douze animaux', T'oung pao, Série II Vol. VII No. 1 p. 96-98). His view can hardly be upheld against the old texts. L. de Saussure ('Les origines de I'astronomie chinoise', T'oung pao 1910, Vol. XI p. 265-288) has already disposed of it. To his counterarguments, with which I concur in general, some more may be added. It is rather surprising that of all the Chinese authors who have written on the five elements almost nobody refers to Tsou Yen whom Chavannes believes to have been the first exponent of the Turkish theory in China. They all go back to the old Chinese sources quoted above. In the fourth or the fifth centuries B. C. when the Turkish theory must have found its way into China, the Turkish tribes, Hsiung-nu or Scythians bordering on the Chinese empire were practically barbarians from whom the Chinese could not learn much. In the Shi-chi chap. 110 they are described as nomads without cities who could not write and did not care for the moral laws. The accounts found in Herodotus Book IV seem to confirm that, at that early age, the Turkish tribes lived in a very primitive state of culture, and it is highly improbable that the theory of the interaction of the elements, supposing a mystical sympathy of all the forces of nature, an attempt at p2.441 a natural philosophy, should have been devised by an uncivilised people like the early Turks. To the Chinese mind such sorts of speculations have been familiar from time immemorial. In ancient times the Turks most likely received the little culture they had from their neighbours, the Chinese, and when, subsequently, the Cakas made their incursions into Bactria and India, from the Greeks and Indians. When, many centuries later, they went over from Buddhism to the Islam, their language as well as their civilisation fell under the influence of the Arabs and Persians. They possessed very little originality, wherefore the invention of the theory of the five elements cannot well be set down to their credit.

I strongly doubt that at the time of Tsou Yen the Hsiung-nu already possessed any notion of the elements, which require a more advanced state of civilisation than theirs was. Their descendants, the Uigurs, know 4 


\section{A. Forke, Introduction and Appendixes to Wang Ch'ung's \\ Lun-hêng}

elements, but which? Fire, wind, water, and earth (Kudatku Bilik by H.Vámbéry p. 75 and 78). They are the same as those of the Greeks and Indians, and they evidently learned them from these directly or through the Arabs, as they must have borrowed the seven planets and the twelve signs of the zodiac from the same source. After deducting these foreign loans, there remains nothing originally Turkish.

Even if the 4 elements: Fire, wind, water, and earth were of Turkish invention, it would not help us much, for the 4 elements of the soi-disant semi-Turkish Ch'in dynasty, according to Chavannes, must have been : fire, p2.442 wood, metal, and earth $i$. e., besides two elements occurring in Europe as well, they embrace two characteristically Chinese elements: wood and metal unknown in Europe and India.

I should say that the principal passage on which Chavannes bases his belief in the Turkish origin of the theory of the five elements, admits of a totally different interpretation than that of the eminent sinologist. The Emperor Han Kao Tsu expressed his astonishinent that in Ch'in only four heavenly emperors were sacrificed to, since he had heard that there were five in heaven. (Mém. Hist. Vol. III, p. 449.) In my opinion this means to say that the emperor knew that before the Ch'in epoch there were five emperors worshipped under the Chou, and that he simply reverted to the old custom, changed by the Ch'in, by instituting a sacrifice to the black emperor, the representative of water.

At first sight the theory of the Five Elements and the classifications ingrafted thereon may seem strange to us, and one of the many Chinese peculiarities, but sociology teaches us that similar classifications, though based on other principles of division, are common all over the world and among people not connected with one another. Such classifications must, therefore, be a product of human nature which is more or less the same everywhere. Consequently, we need not look for a foreign origin of the Chinese theory.

Most Australian natives divide up the things of the world conformably to their clans and fraternities, which, each of them, have their special totems. All 


\section{A. Forke, Introduction and Appendixes to Wang Ch'ung's \\ Lun-hêng}

things belonging to the same group are allied and, so to say, the same reality under different forms. Animals of the same class must not be eaten by their kindred. (E. Durkheim and M. Mauss, De quelques formes primitives de classifications, in L'Année Sociologique, Paris 1901-02, Vol. 6 p. 17.) The totems are not only animals but also plants, fruits and other objects. They may be natural phenomena as well, such as wind, water, the sun, clouds amongst the Aruntas (p. 28 Note 2). With the totem fire are connected the branches of eucalyptus, the red leaves of the érémophile, the sounds of trumpets, warmth, love (p. 31).

A tribe of the Sioux in North America has grouped all objects according to the position occupied by their clans in their camp viz. right, left, in the front, and in the rear (p. 47).

Another tribe of the North American Indians, the Zuñis, have taken the seven directions: north, south, west, east, the zenith, the nadir, and the centre as the basis for their classifications, and filled them up with all the things in which they are specially interested. Thus they have the following equations :

North: wind, winter, the pelican, the crane, the green oak, strength, destruction, yellow.

West : water, spring, moist wind, the bear, the wild dog, vernal herbs, peace, hunting, blue p2.443

South : fire, summer, agriculture, medicine, red

East: earth, seeds, frost, the buck, the antilope, the turkey, magie, religion, white, \&c. (p. 35 seq.).

The Dacotahs have a similar division, but they have lost their clans. The Australian Wotjoballuk have distributed their clans and their correlates over thirteen points of the compass (p. 51).

The classifications according to clans and totems appear to be the more primitive; and those starting from the points of the compass are probably derived from the grouping of the clans in the camp.

It is owing to the preponderance of astrology amongst the Chaldeans that 


\section{A. Forke, Introduction and Appendixes to Wang Ch'ung's \\ Lun-hêng}

with them and their successors, Greeks and Romans, the plants have become the corner stones of very similar classifications. The Chaldeans have attributed the following colours to the planets :

Saturn = black, Jupiter = light red, Mars = purple, the Sun = golden, Venus $=$ white, and Mercury $=$ blue.

Ptolemy gives them somewhat different colours : Saturn = a livid grey, Jupiter $=$ white, Mars $=$ red, the Sun $=$ golden, Venus $=$ yellow, and Mereury = changing colours. The scholiasts also differ and only agree in the colours of Mars (red) and the Sun (golden) (A. Bouché Leclercq, L'Astrologie Grecque, Paris 1899 p. 313, 314).

In addition to colours, metals, plants, and animals are also classified under these planets. Thus mercury is the metal of the homonymous planet ; dragons, snakes, foxes, cats, night birds, donkeys, and hares resort from Saturn ; wild beasts, monkeys, pigs, from Mars (p. 317, 318). Moreover Ptolemy has distributed the parts of the body and the senses among the seven planets according to the following scheme :

Saturn : the right ear, the bladder, the spleen, the phlegm, the bones.

Jupiter: the sense of touch, the lungs, the arteries, the semen.

Mars : the left ear, the kidneys, the veins, the testicles.

Sun : the eyes, the brain, the heart, the nerves - all the chief organs.

Venus : the smells exciting love, the liver, the seat of prophecy, the flesh.

Mercury : the tongue, the gall.

Moon : the taste, the stomach, the womb (p. 321).

This system has undergone a great many modifications at the hands of later authors, for instance Demophilus and Hermippus.

Proclus teaches that the different spheres of the human spirit correspond to the spheres of the stars: Fixed stars = intellectual life, Saturn = contemplation, Jupiter $=$ political and social instincts, Mars = passionateness, Sun = perceptive faculties, Venus = desires, Mercury = faculty of speech, Moon $=$ vegetative life $($ p. 325). 


\section{A. Forke, Introduction and Appendixes to Wang Ch'ung's \\ Lun-hêng}

In the middle-ages the Kabbala sets forth various systems of classification simultaneously. According to the Sepher Iezirah (9th-10th cent. A. D.) p2.444 the world has been built up by the Three Elements named the Three Mothers : fire is the substance of heaven, water that from which the earth was produced, and both antagonistic elements are separated by the third element, air. These Three Elements govern the Three Seasons : summer, the rainy season, and the cool season and the Three Parts of the Body : the head, the breast, and the belly. This gives the following table :

3 Elements
3 Seasons
3 Parts of the World
3 Parts of the Body

\begin{tabular}{|l|l|l|}
\hline fire & water & air \\
summer & rainy season & cool season \\
heaven & earth & void \\
head & breast & belly \\
\hline
\end{tabular}

Besides there are the 'Seven Double Ones' being partly good and partly wicked. These are the Seven Planets and corresponding to them the Seven Days and the Seven Nights of a week, and the Seven Orifices of the Head.

The 'Twelve Single Ones' are the Twelve Months combined with the Twelve Signs of the Zodiac and the Twelve Human Activities : sight, hearing, smell, touch, speech, nutrition, generation, motion, anger, laughing, thought, and sleep. (A. Lehmann, Aberglauben und Zauberei, 2nd ed., translated by Petersen, Stuttgart 1908 p. 145 seq.)

At the end of the middle-ages, these classifications received their highest development in Europe by the mystic Agrippa von Nettesheim (1456-1535 A. D.) who in his great work 'De occulta philosophia' combined the Physics of Aristotle, the astronomy of Ptolemy, the New Platonism, and the Kabbala with his own observations and fanciful ideas. His works and those of his contemporaries show us that in the beginning of the 16th century people in Europe were not a whit farther advanced in natural science than the Chinese philosophers of the Sung epoch or those of today. Many of the arguments of Agrippa remind us of similar ones of the Chinese theorists of the Five Elements.

Agrippa maintains that everything is subject to a planet or a constellation. Thus fire and blood are solar, and the same is said of gold, and of the precious stones : pyrope, heliotrope, jasper, emerald, ruby, the sun-flower, the lotus flower, and the big and audacious animals : the lion, the crocodile, 


\section{A. Forke, Introduction and Appendixes to Wang Ch'ung's \\ Lun-hêng}

the ram, the bull, the phœnix, the eagle, the cock, the raven. Similar lists are given for all the planets.

Everything on earth is classified according to fixed numbers. Agrippa has established groups and classes of 1-12 links each, and combined them to systems, following perhaps the precedent of the Kabbala. As a specimen I give his table of the Seven Planets :

\begin{tabular}{|c|c|c|c|c|c|c|c|c|}
\hline In the world & \multicolumn{7}{|c|}{ A Sh R A H I H = Asher Eheie } & \multirow{2}{*}{$\begin{array}{c}\text { God's name } \\
\text { In } 7 \text { letters } \\
7 \text { angels before } \\
\text { God's face }\end{array}$} \\
\hline $\begin{array}{c}\text { In the } \\
\text { world of ideas }\end{array}$ & Zaphkiel & Zadkiel & Chamael & Raphael & Haniel & Michael & Gabriel & \\
\hline $\begin{array}{c}\text { In the } \\
\text { heavenly world }\end{array}$ & Saturn & Jupiter & Mars & Sun & Venus & Mercury & Moon & 7 planets \\
\hline $\begin{array}{l}\text { In the } \\
\text { Elementary world }\end{array}$ & $\begin{array}{c}\text { whoop } \\
\text { cuttle-fish } \\
\text { mole } \\
\text { lead } \\
\text { onyx }\end{array}$ & $\begin{array}{l}\text { eagle } \\
\text { dolphin } \\
\text { stag } \\
\text { tin } \\
\text { sapphire }\end{array}$ & $\begin{array}{l}\text { vulture } \\
\text { pike } \\
\text { wolf } \\
\text { iron } \\
\text { diamond }\end{array}$ & $\begin{array}{l}\text { swan } \\
\text { seal } \\
\text { lion } \\
\text { gold } \\
\text { pyrope }\end{array}$ & $\begin{array}{l}\text { pigeon } \\
\text { shad-fish } \\
\text { ram } \\
\text { copper } \\
\text { emerald }\end{array}$ & $\begin{array}{l}\text { stork } \\
\text { blenny } \\
\text { monkey } \\
\text { mercury } \\
\text { agate }\end{array}$ & $\begin{array}{l}\text { night-owl } \\
\text { sea-cat } \\
\text { cat } \\
\text { silver } \\
\text { crystal }\end{array}$ & $\begin{array}{l}7 \text { planetary birds } \\
7 \text { planet. fish } \\
7 \text { planet. animals } \\
7 \text { planet. metals } \\
7 \text { planet. stones }\end{array}$ \\
\hline $\begin{array}{c}\text { In the } \\
\text { world of men }\end{array}$ & $\begin{array}{l}\text { right foot } \\
\text { right ear }\end{array}$ & $\begin{array}{l}\text { head } \\
\text { left ear }\end{array}$ & $\begin{array}{l}\text { right hand } \\
\text { right nostril }\end{array}$ & $\begin{array}{l}\text { heart } \\
\text { right eye }\end{array}$ & $\begin{array}{l}\text { pudenda } \\
\text { left nostril }\end{array}$ & $\begin{array}{l}\text { left hand } \\
\text { mouth }\end{array}$ & $\begin{array}{l}\text { left foot } \\
\text { left eye }\end{array}$ & $\begin{array}{l}7 \text { members } \\
7 \text { orifices } \\
\text { of the head }\end{array}$ \\
\hline $\begin{array}{c}\text { In the } \\
\text { infernal world }\end{array}$ & Gehenna & $\begin{array}{l}\text { gate of } \\
\text { death }\end{array}$ & $\begin{array}{c}\text { shadow of } \\
\text { death }\end{array}$ & $\begin{array}{l}\text { well of } \\
\text { death }\end{array}$ & slough & perdition & abyss & $\begin{array}{l}7 \text { dwellings } \\
\text { of the damned }\end{array}$ \\
\hline
\end{tabular}

p2.446 After this historical and sociological excursion we return to the period where we left the subject. We possess still more sources dating from that time, though not classical ones, proving that already then the table derived from the Liki was still further developed :

The Taoist writer Ho Kuan Tse (4th cent. B. C.) arranges the Five Elements according to the position taken by soldiers in a camp, referring them to the human body, and not to the four quarters.

«In choosing a position, he says, one must take advantage of the ground and select it according to the Five Elements. Wood is on the left side, metal on the right, fire in front, water in the rear, and earth in the centre. In army camps, and in marshalling troops this order must be observed. These five divisions being well defined, everything may be undertaken with safety.

This arrangement of the elements agrees with their positions in the four quarters, if the observer turns his face to the chief quarter, which for the 


\section{A. Forke, Introduction and Appendixes to Wang Ch'ung's \\ Lun-hêng}

Chinese is the south. Then fire is in the front or in the south, water in the rear or in the north, wood on the left side or in the east, metal on the right side or in the west, and earth, in both cases, remains in the centre.

The Huang Ti su-wên, the oldest work on Chinese medicine - which Wylie places several centuries before Christ, so that it would be a relic of the Chou time - devotes several chapters to the theory of the Five Elements. This theory has remained the basis of all Chinese medicine up to the present day. As appears from the title of the work, it consists of questions addressed by Huang Ti to his assistant Ch'i Po. This, of course, is fiction.

« Huang $\mathrm{Ti}$ asked in what manner cold and heat, dryness and moisture, wind and fire operated on man, and how they produced the transformations of all things.

Ch'i Po replied about the operation of these six atmospherical influences in the five quarters. For our purpose it suffices to consider what he says about heat and cold, and their derivates. A strict parallelism goes through all his deductions :

«The south produces heat, heat produces fire, fire produces bitterness, bitterness the heart, the heart blood, and blood the spleen. In heaven it is heat, on earth it is fire, and in the body, the veins. As a breath it respires, and among the viscera, it is the heart. Its nature is hot, its quality effulgence, its manifestation drying up. Its colour is red, its transformation luxuriance, its creatures the feathered ones, its government enlightenment, its weather sultry, its sudden change burning, its calamity a conflagration. Its taste is bitter, its sentiment joy. Joy injures the heart, but fear overcomes joy. Heat p2.447 injures the breath, but cold overcomes heat, and bitterness injures the breath, but salt overcomes bitterness.

The north produces cold, cold produces water, water produces salt, salt the kidneys, the kidneys produce bones and marrow, the marrow produces the liver. In heaven it is cold, on earth it is water, and in the body, the bones. As a breath it is hard, and among the viscera it is the kidneys. Its nature is glacial, its quality 


\section{A. Forke, Introduction and Appendixes to Wang Ch'ung's \\ Lun-hêng}

cold, and its manifestation...... ${ }^{1}$ Its colour is black, its transformation frost, its creatures are the shell-covered, its government is quiet, its weather...... its sudden change is freezing, its calamity ice and hailstones. Its taste is salt, its sentiment fear. Fear injures the kidneys, but desire overcomes fear. Cold injures the blood, but dryness overcomes cold. Salt injures the blood, but sweetness overcomes salt.

Ch'i Po winds up by saying,

- The Five Fluids come forward in turn, and each of them takes precedence once. When they do not keep in their proper spheres, there is disaster ; when they do, everything is well ordered.

The Huang Ti su-wên adds some more categories to those given by the LiKi : the 5 styles of government: Relaxation, enlightenment, carefulness, energy, and quietude, the 5 impulses : anger, joy, desire, sorrow, and fear, and the 5 constituent parts ot the body :muscles, p2.448 veins, flesh, skin and hair, and bones. The 5 intestines or viscera are the same as those of the Liki, but their sequence is different, and in each class, in addition to the principal intestine, a secondary one is introduced, viz. every secondary one is the principal intestine of the next class.

As to the theory of the Five Elements, the medical work agrees with the Shuking and the Tso-chuan whose general hints it specifies. It distinguishes three spheres of the elements, which in each of them appear in different forms, the spheres of heaven, of earth, and of man, just as Agrippa has seven spheres. The original form of the elements is that of the Six Fluids or atmospheric influences: cold and heat, dryness and moisture, wind and fire ${ }^{2}$. They produce the five elements on earth, but in combining each element with a fluid the author drops fire. All the other diverse forms of the elements are the result of constant transformations, which to us appear very

1 Lacuna in the text.

2 The Six Fluids of the Tso-chuan, not expressely mentioned, would be different, if the commentators are right. Cf. p.436. But they practically agree with the Five Fluids of the Shuking : rain, sunshine, heat, cold, and wind (see above p. 433), leaving aside fire. 


\section{A. Forke, Introduction and Appendixes to Wang Ch'ung's \\ Lun-hêng}

strange. How can fire produce bitterness, bitterness the heart, the heart blood, and blood the spleen? The qualities and manifestations of the elements described in the work are more in accordance with nature.

But what does it mean that

« fear injures the kidneys, but desire overcomes fear. Cold injures the blood, but dryness overcomes cold. Salt injures the blood, but sweetness overcomes salt,

and the like passages under the other heads ? These are merely equations deducted from the theory of the antagonism of the elements, and seem to be the basis for the medical treatment of the parts of the body. We know that fear may affect the kidneys, and that a strong desire may vanquish fear. The last conclusion, however, the Chinese theorist probably did not draw from practice, but from the premisses that desire corresponds to earth, and fear to water. Consequently, earth overcoming water, desire must vanquish fear likewise. In the same manner cold (water) injures the blood (fire), and dryness (metal) again overcomes cold (water), not directly, it is true, but indirectly, for metal overcomes wood, wood earth, and earth water. Moreover salt (water) injures the blood (fire), but sweetness (earth) vanquishes salt (water).

The new classes of the Huang Ti su-wên are thus grouped :

\begin{tabular}{|c|c|c|c|c|c|}
\hline $\begin{array}{l}5 \text { Fluids } \\
5 \text { Elements } \\
5 \text { Parts of Body } \\
5 \text { Intestines } \\
5 \text { Impulses } \\
5 \text { Styles of } \\
\text { Government }\end{array}$ & $\begin{array}{l}\text { wind } \\
\text { wood } \\
\text { muscles } \\
\text { liver (heart) } \\
\text { anger } \\
\text { relaxation }\end{array}$ & $\begin{array}{l}\text { heat } \\
\text { fire } \\
\text { veins (blood) } \\
\text { heart (spleen) } \\
\text { joy } \\
\text { enlightenment }\end{array}$ & $\begin{array}{l}\text { moisture } \\
\text { earth } \\
\text { flesh } \\
\text { spleen(lungs) } \\
\text { desire } \\
\text { carefulness }\end{array}$ & $\begin{array}{l}\text { dryness } \\
\text { metal } \\
\text { skin and hair } \\
\text { lungs(kidneys) } \\
\text { sorrow } \\
\text { energy }\end{array}$ & $\begin{array}{l}\text { cold } \\
\text { water } \\
\text { bones(marrow) } \\
\text { kidneys (liver) } \\
\text { fear } \\
\text { quietude }\end{array}$ \\
\hline
\end{tabular}

p2.449 Each element preponderates during one season, and, while so doing, it may be well balanced and have its proper quantity, it may be excessive or deficient. Excess and deficiency both entail calamities affecting the vegetation and human body. In the latter case we have all kinds of diseases and maladies. All these states are minutely described, and still more categories added. Each element in its proper state of equilibrium is said to be governed by a part of the body different from those already mentioned : the eye, the tongue, the mouth, \&c. Moreover it is connected with two sorts of 


\section{A. Forke, Introduction and Appendixes to Wang Ch'ung's \\ Lun-hêng}

fruit, a fleshy and a not fleshy - wood for instance with a plum and a nut and with a domestic animal like the dog, the horse, \&c. Even in its felicitous state each element has a special sickness assigned to it : palpitations and convulsions belong to fire, coughing to metal, constipation to earth. The classes of the Liki are again ascribed to the elements well balanced, but not in the proper order. Thus e. $g$. wood is combined with hemp, the hairy creatures, and the liver ; fire has as correlates: wheat, feathered creatures, and the heart.

In case a ruling element be excessive or insufficient, two or more things of the same sort are made to correspond to it, whereas as a rule there is only one. There may be two fruits, two animals, two colours, two tastes corresponding to one element; even three are combined, probably to show the irregularity of the ruling element. At the same time the Five Planets are introduced as correlates of the elements, mostly two or three connected with one element. Thus we find Jupiter and Venus in connection with excessive wood, Mars and Mercury combined with excessive fire, Venus and Mars together with insufficient wood, and Mars, Mercury, and Saturn together with insufficient fire.

All irregularities of the elements entail a great variety of diseases. Whenever wood is superabundant, earth and the spleen have to suffer. This leads to pains in the limbs, flatulency, diarhœa, and vomiting. A scarcity of wood is accompanied by pains of the ribs and the stomach, by coughs and catarrhs, eruptions, scarlatina, sores and ulcers. A scarcity of fire causes pains in the breast, the back, the shoulders, the arms, the heart, rhumatism, cramps, paralysis of the legs, dumbness, swooning, \&c.

Whereas the Huang Ti su-wên insists upon the effects of the irregularities of the elements upon man, the philosopher Kuan Tse of the 5th century B. C. attempts to show how natural events, connected with the elements, are influenced by the government of the emperor. We must bear in mind that the work passing under Kuan Tse's name and forming part of the collection of the Ten Philosophers, contains many later additions and is only partly genuine. But the style of the chapters on the Four Seasons and the Five Elements which interest us most, is rather archaic, and they may well be old. 


\section{A. Forke, Introduction and Appendixes to Wang Ch'ung's \\ Lun-hêng}

«Yin and Yang, says Kuan Tse, are the great principles of heaven and earth, and the Four Seasons are the warp in the web of Yin and Yang. Punishments and rewards are the correlates of the Four Seasons. Their conformity to the seasons brings about happiness, their discrepancy leads to misfortune ${ }^{1}$. (Kuan Tse XIV, 7r.)

Then Kuan Tse proceeds to describe the seasons in a similar way as the Liki does, but, whereas the Liki distinguishes but Four Seasons, earth having no special one and belonging to all, Kuan Tse gives Five Seasons 2, each lasting 72 days. Besides he joins a special heavenly body to every quarter: the centre corresponds to the earth, the south to the sun, the north to the moon, the east to the stars, and the west to the zodiacal signs. For each of the Four Seasons five administrative measures are prescribed, the carrying out of which ensures felicity, whereas their omission or change is fraught with disaster. In the opinion of one commentator each season would have counted 90 days, and to each of the five administrative measures 18 days would have been allotted. Thus our author says in regard to winter :

«In the three winter months, on the jên-kuei ${ }^{3}$ days five administrative measures are carried out. The first is providing for orphans and destitute persons and succouring the old and the aged ; the second is conforming to the Yin, preparing the sacrifices for the spirits, bestowing titles and emoluments, and conferring ranks; the third is verifying accounts, and not to exploit the treasures of mountains and rivers; the fourth is rewarding those who seize runaway criminals and arrest robbers and thieves; the fifth is prohibiting the moving about of the people, stopping their wanderings, and preventing their settling in other parts of the empire. If these five measures are taken at the proper time, so

\footnotetext{
1 As will be seen in the following, rewards are in accordance with spring and summer, punishments with autumn and winter. From time immemorial capital punishment in China has been meted out in autumn and winter, so that the Chinese have come to consider this the natural course of nature.

2 In the chapter on the Five Elements, XIV, 16v. seq. In the preceding one on the Four Seasons, XIV, p. 8v. he still adheres to the theory of the Four Seasons, stating that earth, the element of the centre, helps the Four Seasons.

3 See below p. 452, Note 2.
} 


\section{A. Forke, Introduction and Appendixes to Wang Ch'ung's Lun-hêng}

that the affairs of winter are p2.451 not disregarded, one obtains one's wishes, and that which one dislikes do not take place ${ }^{1}$.

Kuan Tse then proceeds to show how an emperor should act conformably to the Four Seasons :

«If plants wither in spring and blossom in autumn, if it thunders in winter, and there is frost and snow in summer, all this is harm caused by the fluids. If regarding rewards and punishments the periods are changed, and the natural order is confounded, then injurious fluids quickly arrive, and, upon their arrival, the State is visited with many disasters. Therefore a wise emperor observes the seasons and accordingly regulates his administration. He provides education and makes his warlike preparations, offers sacrifices and thereby establishes virtue. It is by these three things that a wise emperor puts himself into harmony with the movement of heaven and earth.

The sun governs the Yang, the moon the Yin, the stars govern harmony. Yang produces rewards, Yin punishments 2, and harmony makes business possible. Consequently when there is an eclipse of the sun 3 , a State that has failed in its rewards is to be blamed for it. When there is an eclipse of the moon ${ }^{4}$, a State that has failed in its punishments is responsible. When a comet puts in an appearance, a State that has lost harmony is guilty, and when

\footnotetext{
1 The Chinese probably discovered some analogies between these measures and winter, and for that reason prescribed them : There is some similarity between the desolateness of winter and destitute persons. Winter, being the end of the year, may be compared with old and aged persons. We ourselves personify it by an old man, and spring by a young boy, In winter the Yin principle is at its height, and incorporeal spirits belong to it. Accounts use to be settled at the end of the year. The hidden treasures of mountains and rivers must not be moved, because hiding and torpidity is the nature of winter. The forces of nature do not move, hence the moving about of the people is prohibited. Criminals, as we have seen, are called to account in autumn and winter.

2 The Yang is warm and thus may be symbolised by warmth of heart, benevolence and rewards. Yin is cold and has an analogy in cold-hearted severity and punishments.

${ }^{3}$ An eclipse of the sun, the chief representative of the Yang, means that rewards have been incomplete.

4 The moon again represents the Yin fluid and punishments. Its partly annihilation shows that punishments have been insufficient.
} 


\section{A. Forke, Introduction and Appendixes to Wang Ch'ung's Lun-hêng}

wind fights with the sun for brightness, a State that has failed in productiveness is answerable ${ }^{1}$. Wherefore, at an 2.452 eclipse of the sun, a wise emperor improves rewards; at an eclipse of the moon, he improves punishments; when a comet becomes visible, he improves harmony, and when wind and sun fight together, he improves production. By these four measures the wise emperor avoids the punishments of heaven and earth ${ }^{2}$.

The disasters which may befall a sovereign not conforming to the seasons in his administration are thus described :

«When we see the cyclical sign chia-tse ${ }^{3}$ arrive, the element wood begins its reign. If the son of heaven does not bestow favours or grant rewards and, contrariwise, extensively allows cutting, destroying, and wounding 4 , then the sovereign is in danger, and should he not be killed, then the heir-apparent would be in danger, and some one of his family or his consort would die, or else his eldest son would lose his life. After 72 days this period is over. When we see the cyclical sign ping-tse arrive, the element fire begins its reign. In case the son of heaven be anxious to take hurried and hasty measures 5 , an epidemic would be caused by a drought 6 , plants would die, and the people perish by it. After 72

\footnotetext{
1 Wind is the fluid of spring, the characteristic feature of which is productiveness. Fighting for brightness must signify that wind chasing the clouds attempts to obscure the brightness of the son, which now and then breaks through the clouds.

2 Kuan Tse XIV, $11 \mathrm{~V}$.

3 This is the cyclical sign of the day beginning the period of 72 days assigned to the element wood. Here we have a key to the understanding of the pairs of cyclical signs joined to each element in the Liki, the meaning of which was not clear to Legge. The days of spring are chia and $y i$ (cf. p. 438) means nothing else than that the first and the second days of this season bear these signs, being in the sexagenary cycle chiatse and yi-chou. Summer begins when we arrive at the sign ping-tse, after having passed through the entire cycle of 60 , adding 12 , i. e., after 72 days. The second day of summer or of the element fine is a ting-chou day, so that the Liki may say that the days of summer are ping and ting, \&c. Of course, the assigning of three full months to each season by the Liki is not in keeping with these cyclical signs, which can only be applied to seasons of 72 days.

${ }^{4}$ Spring is the time of growth, but not of destruction.

5 According to a commentator this is the season of ease and indulgence.

6 A drought is a consequence of too much heat symbolised by hurried and hasty actions.
} 


\section{A. Forke, Introduction and Appendixes to Wang Ch'ung's \\ Lun-hêng}

days this period is over. When we see the sign wu-tse arrive, the element earth begins its reign. If the son of heaven builds palaces or constructs kiosques, the sovereign is in danger, and if without city walls are built ${ }^{1}$, his ministers die. After 72 days this period is over. When we see the sign kêng-tse arrive, the element metal begins its reign. Should the son of heaven attack p2.453 the mountains and beat the stones 2 , his troops would be defeated in war, and his soldiers die, and he would lose his sway. Alter 72 days this period is over. When we see the sign jên-tse arrive, the element water begins its reign. If the son of heaven cuts the dykes and sets the great floods in motion, his empress or his consort die, or else the eggs of birds become addled, the hairy young are miscarried, and pregnant women have an abortion. Plants and trees are spoiled in the roots. After 72 days this period is over ${ }^{3}$.

Among the authors of the Han time Huai Nan Tse and Tung Chung Shu, both of the 2nd century B. C., have written more or less systematically on the theory of the Five Elements, to which several chapters of their chief works are devoted. Liu Hsiang in the 1st century B. C. emposed the Wu-hsing-chih, a treatise on the Five Elements which has not come down to us. Pan Ku of the 1st century A. D. discourses at some length on the subject in his Po-hu-t'ung. Afterwards it was taken up by a great many writers and forms an important part of the disquisitions of the philosophers of the Sung dynasty.

We are now going to consider the results at which these writers and their predecessors have arrived.

\section{Various terms for the Elements}

The modern work Chang-huang t'u-shu pien states that in the Yiking the Five Elements are named Wu-wei, Five Positions ${ }^{4}$, in historical works $W u$ -

\footnotetext{
${ }^{1}$ By building the element earth is disturbed.

2 This again would mean a disturbance of the metal hidden in the mountains.

3 Kuan Tse XIV, 18v. (Shih-tse chüan-shu).

4 The utterances of the Yiking are very obscure and I doubt whether they really refer
} 


\section{A. Forke, Introduction and Appendixes to Wang Ch'ung's \\ Lun-hêng}

tsai, Five Materials, in chronicles or essays Wu-wu, Five Things, and in medical works Wu-yün, Five Revolutions. Mayers (Manual p. 313) gives some

more terms : Wu-chieh, Five p2.454 Sections, Wu-mei, Five Excellencies, and Wu-ch'i, Five Fluids. They are descriptive of the elements under various aspects, as substances formed of matter, as fluids or vapours, as moving and revolving, or as keeping certain positions. But by far the commonest expression is Wu-hsing, on the meaning of which the Chinese and foreign authorities are agreed. hsing is 'to $a c t$ ' and 'to move', the $W u$-hsing are, therefore, the five essences which are always active and in motion. Mayers (loc. cit.) calls them the primordial essences or perpetually active principles of nature. The term is all but equivalent to Wu-yün, the Five Revolutions.

\section{What are the Five Elements?}

The designation Wu-hsing goes back to the Shuking and implies that at these remote times the elements were conceived already as ever active essences, which again supposes the existence of some sort of a theory devised to explain the phenomena of nature. In the most ancient description of the elements contained in the Shuking (cf. above p. 433) they are considered from the physical point of view as natural substances : water has the tendency of descending and soaking other stuffs, fire that of rising and blazing ; wood is characterised as crooked and straight, which seems to refer to the appearance of the branches of trees; metal is said to be yielding and changing, which is only true of metal in a liquid state ; earth is not described any further, and its nature found in its generative and productive power. At all events, the authors of the Classic had not some metaphysical entities in view, but the substances usually understood by the names: water, fire, wood, metal, and earth.

As to the impressions produced by these elements upon our senses and resulting in the categories of colours, sounds, tastes, and smells, the Shuking

to the elements. 


\section{A. Forke, Introduction and Appendixes to Wang Ch'ung's \\ Lun-hêng}

concerns itself with tastes only: Water becomes salt, fire bitter, wood sour, metal acrid, and cereals, the produce of earth, sweet. Of course pure water is not salt, but tasteless, yet, as the commentators remark, it becomes salt in the ocean, a wrong notion. Fire we would rather describe as burning than bitter, and wood as bitter instead of sour. The acrid taste of metals and the sweet one of cereals, such as rice and millet, may pass. It is difficult now to say which considerations led the ancient Chinese to attribute just these tastes to the five elements. Since the five tastes are always given in the series: salt, bitter, sour, acrid, sweet, it is not impossible that the ancients merely coupled them with the five elements of the Shuking in the same order, without any regard to their natural relations.

In the same superficial manner the five colours : black, red, green, white, and yellow may have been connected with the five elements, although the correspondencies have been explained: Fire may well be described as red, though yellow would seem more appropriate. Wood appears green at least outwardly in plants and trees, whereas inwardly it is mostly white p2.455 or yellow. The colours of metals are manifold, only their glittering may be said to be white. Earth is not yellow in most countries, but it was so in the loess regions in Honan and Shansi where the Chinese were first settled. How can water be called black, however, a colour it almost never shows ? It seems to refer to the Yin fluid preponderating in winter, the time of the element water. Yang is light and sunshine, Yin darkness, Yang, day-time, and Yin, night. These correspondencies are universally accepted, but I met with one exception in the 'Family Sayings of Confucius' ${ }^{1}$ chap. VI p. 1, from which we learn that the Hsia dynasty reigned by the virtue of metal and of the colours most appreciated black, the Yin dynasty reigned by water and appreciated white, the Chou by wood with the red colour. Yao's element was fire, and his colour yellow, Shun's element earth, and his colour green. These different combinations of elements and colours show the arbitrariness of the whole scheme. It is impossible to find one colour for each element, because each embraces many species with different colours : Water may appear pellucid,

\footnotetext{
${ }^{1}$ A work dating from the 3 rd cent. A. D. I doubt whether this chapter treating of the Five Elements really goes back to Confucius, since he is made to say that he was informed about the elements by Lao Tse.
} 


\section{A. Forke, Introduction and Appendixes to Wang Ch'ung's \\ Lun-hêng}

white, green, blue, red, yellow, grey, black; earth may be black, brown, yellow, red, blue, white, \&c. ${ }^{1}$; and so different substances burn with different lights. Therefore to ascribe one colour to each element cannot but be arbitrary.

The Zuñis of North America have no elements 2 , but they have attributed certain colours to their seven points of the compass. Their reasons for doing so are not very convincing either: The North is yellow, because at sunrise and sunset the sunlight appears yellow. The West is blue, the colour of the evening light. The East is white, the colour of day, the South red, because it is the seat of summer and of the red fire. The Zenith is multicoloured like the clouds, the Nadir black, and the Centre has all colours. (Année Sociologique Vol. VI, p. 35 seq.)

Of the Five Smells only burning and fragrant seem to refer to the corresponding elements fire and earth (cereals). Goatish, rank, and rotten have nothing to do with wood, metal, and water. They probably apply to the Five Animals joined to these elements : the sheep (goat), dog, and pig.

On the principle by which the Five Sounds have been combined with the elements I am unable to express any opinion.

Kuan Yin Tse 3 has amplified the statement of the Shuking about the rising and descending of fire and water :

«That which rises, he says, is p2.456 fire; that which descends, water. That which would like to rise, but cannot, is wood ; and that which would like to descend, but cannot, is metal.

This depicts fairly well the tendency of plants of growing up and that of metals of sinking down. These tendencies, however, are restricted and less free than those of fire and water which, endowed with a greater agility as air and fluid, can follow their propensities and rise and fall.

\footnotetext{
1 If we speak of the green earth we regard its coat, the green vegetation, as part of it. 2 That is to say, they have not conceived the idea of the elements, but ascribe the single ones to the four quarters like the Chinese : Wind belongs to the North, water to the West, fire to the South, and earth to the East.

3 A Taoist author, but the work bearing his name, is believed to be a production of the T'ang or the following minor dynasties, 618-960 A.D.
} 


\section{A. Forke, Introduction and Appendixes to Wang Ch'ung's \\ Lun-hêng}

The Chang huang t'u-shu pien makes an attempt to distinguish between the different forms of the elements: water is level, fire is pointed, earth round, wood crooked and straight, and metal square ${ }^{1}$. These are indeed the forms under which these substances often appear to us. Whereas water shows a level surface, a flame rises and seems pointed. Clods of earth are more or less round, and ore has often angular and square shapes. The description of wood as crooked and straight is taken from the Shuking.

It is but natural that the Chinese should have connected their Five Elements with the two principles of nature established by their old philosophers, the Yin and Yang, and derived them therefrom. Tung Shung Shu says in his Ch'un-ch'iu fan-lu XIII, 5v. that the fluid of Heaven and Earth united is one. But it splits into Yin and Yang, becomes divided into the Four Seasons, and separated into the Five Elements ${ }^{1}$. Yin and Yang, which we may here translate by cold and heat, are the primogenial essences from which the Five Elements are produced in the following way: Water has its seat in the north which is governed by the Yin fluid. Wood is placed in the east which is likewise under the sway of the Yin, but the Yang begins to move already. Fire occupies the south where the Yang reaches its climax. Metal rests in the west, and is governed by the Yang, but the Yin begins to stir. Consequently

«Fire is Yang, it is noble and therefore rises; water is Yin, it is mean and therefore goes down; wood is a scanty Yang, and metal a scanty Yin. (Pan Ku's Po-hu-t'ung II, 1.)

The idea is quite clear, if we take into consideration the Four Seasons with which the elements are combined. In summer ruled by fire, p2.457 Yang = heat prevails, in winter ruled by water, Yin = cold. In spring and autumn when wood and metal are paramount, Yin and Yang, heat and cold fight together, so that one may speak of a scanty Yang or an incomplete Yin. The element earth which does not well agree with the Four Seasons is left out by Pan Ku.

\footnotetext{
1 In another chapter the same author gives [...] as the shapes of the elements. [] 'straight' seems to stand for 'level', and [] 'crooked' alone for 'straight and crooked', the shape of wood.
} 


\section{A. Forke, Introduction and Appendixes to Wang Ch'ung's \\ Lun-hêng}

Later authors have gone more into details. Tse Hua Tse (Sung dynasty) characterises fire as an abundant Yang, and water as an abundant Yin, wood as a scanty Yang, metal as a scanty Yin, and earth as sometimes Yin and sometimes Yang.

« The Yang in the Yang is fire, he says, the Yin in the Yin is water, the Yin in the Yang is wood, the Yang in the Yin is metal. Earth keeps in the middle between the two essences and thus governs the four quarters : in the Yin it is Yin, and in the Yang it is Yang. (Tse Hua Tse II, 11 v.)

« In the north the extreme Yin resides. It produces cold, and cold engenders water. In the south the extreme Yang resides, which produces heat, and heat produces fire. In the east the Yang is set in motion. It disperses and calls forth wind, which again produces wood. In the west the Yin stops and gathers. It thus causes dryness, which produces metal. In the centre the Yin and the Yang mix and produce moisture which engenders earth ${ }^{2}$.

In other words fire is considered to be Yang throughout, Yang in Yang, $i$. e., an unalloyed Yang ; water, a pure and genuine Yin. Wood is also Yang, but with an admixture of Yin ; metal is Yin, but with an alloy of Yang. Earth may be both.

Chu Hsi and his school take a somewhat different view. They look upon the Five Elements as created by Heaven and Earth alternately, Heaven and Earth thus taking the place of the Yin and the Yang.

« Heaven first creates water, Earth secondly creates fire, Heaven thirdly creates wood, Earth fourthly creates metal 3.

This idea seems to have originated from an obscure passage of the Yiking believed to refer to the Five Elements. p2.458 Chu Hsi quotes the famous Su Tung P'o (1036-1101 A. D.) as his authority, who says that water is the extreme Yin, but it requires Heaven to co-operate before it can be produced.

1 Han-Wei t'sung-shu.

2 Tse-shu po-chia.

3 T'u-shu chi-ch'êng. 


\section{A. Forke, Introduction and Appendixes to Wang Ch'ung's \\ Lun-hêng}

Yin alone without Yang cannot produce it. Fire is the extreme Yang, but it likewise requires the co-operation of Earth to come into existence. And so it is with all the Five Elements, they all cannot be created, unless the Yin and the Yang are both at work. When the Yang is added to the Yin, water, wood, and earth come forth, and when the Yin is added to the Yang, fire and metal are produced.

About the creation of the elements and their nature Chu Hsi further asserts that by the joint action of Yin and Yang water and fire are first produced. Both are fluids flowing, moving, flashing, and burning. Their bodies are still vague and empty, and they have no fixed shape. Wood and metal come afterwards. They have a solid body. Water and fire are produced independently, wood and metal need earth as a substratum from which they issue. Heaven and Earth first generate the light and pure essences, water and fire, afterwards the heavy and turbid ones, wood, metal and earth. The last is the heaviest of all. As to their density, water and fire are shapeless and unsubstantial fluids, fire, hot air in the atmosphere, wood is a soft substance, metal a hard one.

Chou Tse, a predecessor of Chu Hsi, gives still another formula for the elements : water is the moist fluid in the Yang, fire, the dry fluid in the Yin, wood, the moist fluid in the Yang, but expanded, metal, the dry fluid in the Yin contracted, earth the Yin and the Yang blended and condensed, so as to become a substance. Yang and Yin, heat and cold are allotted to the Five Elements in the same manner as by Chu Hsi, but as a secondary constituent we have moisture and dryness. These are the same principles from which Aristotle has evolved his Four Elements : earth, water, fire, and air. The Chinese have become acquainted with his theory by the geographical work K'un-yü t'u-shuo written by the Jesuit father Verbiest about the end of the 17th century and cited by the T'u-shu chi-ch'êng. According to the Aristotelian theory dryness and cold produce earth, moisture and cold produce water, moisture and heat give air, and dryness and heat give fire. The result arrived at by 2.459 Chou Tse is different, he only composes earth similarly namely by heat and cold (Yin and Yang). His water consists of moisture and heat (Yang) instead of cold, and his fire, of dryness and cold (Yin) instead of heat. The Aristotelian view appears more natural than that of Chou Tse who is under 


\section{A. Forke, Introduction and Appendixes to Wang Ch'ung's \\ Lun-hêng}

the spell of the Yiking. Perhaps Tse Hua Tse agrees with the Greek philosopher, for his above mentioned dictum that fire is the Yang in the Yang, and water the Yin in the Yin may be understood to mean that fire is dryness in heat, and water, moisture in the cold, Yang denoting heat as well as dryness and Yin cold and moisture.

\section{Fluids, Substances, and Seasons}

Originally the elements were not combined with the Seasons. The fact that there always have been Five Elements, but Four Seasons, and that our oldest sources do not allude to such a connexion, tells against it. On the other side, the term 'Wu-hsing' makes it plain that the Five Elements were conceived already in times immemorial as something more than simple substances. From the passage of the Tso-chuan where the elements are mentioned together with the heavenly fluids, which become the Five Tastes, the Five Colours and the Five Sounds, and even manifest themselves in human affections (cf. p. 436) we may gather that, at a very early date, the elements were identified with the heavenly fluids or atmospherical influences. These are in the Shuking : rain, sunshine, heat, cold, and wind. They again, I presume, formed the link with the Four Seasons, which in the opinion of the Chinese, who did not know the real cause of the seasons, are the result of the regular changes of the heavenly fluids. In the Liki elements and seasons are linked together already. Kuan Tse, XIV, 7 seq. asserts that wind produces wood, the Yang fluid fire, the Yin fluid metal, and cold, water. Earth has no special fluid.

The Sung philosophers were the first clearly to point out the difference of substances and fluids. Substances are produced, says Chou Tse, by the interaction and coagulation of the Yin and the Yang, whereas the Fluids are the regular revolutions of these two primary essences. T'sai Ch'ên, a disciple of Chu Hsi, holds that in heaven the Five Elements are the Five Fluids : rain, sunshine, heat, cold, and wind, and on earth the Five Substances: water, wood, fire, metal, earth. Of the Five Heavenly Fluids rain and sunshine are the substances, which seems to imply that they are more substantial than 


\section{A. Forke, Introduction and Appendixes to Wang Ch'ung's \\ Lun-hêng}

heat, cold, and wind - and of the Five Substances of Earth water and fire are the fluids - possessing more the nature of fluids than of substances, a view held by Chu Hsi also, as we have seen above. p2.460 Another writer maintains that the substances adhere to and have their roots in the earth, and that the fluids revolve in heaven. The latter generate, the former complete all organisms, $i$. e., the fluids give the first impulse to every new creation and the substances complete it. It may not be out of place to point out that the aforementioned Agrippa puts forward quite similar ideas. The elements in the lower worlds he declares to be coarser and more material, whereas in the higher spheres they appear only as forces or qualities. (Lehmann, Aberglaube p. 198.)

This view has again been modified, all elements heing held to be compounded of substance and fluid. There is a difference between the various elements insomuch as they are more substantial or more etherial.

« Fire and water have much fluid and little substance, wherefore they were produced first. Metal and wood have much substance and little fluid, and for this reason were created later. In earth substance and fluid are equally balanced, consequently it came after water and fire, but preceded metal and wood.

« The fluid of water is Yang, its substance Yin. The nature of Yin is procreative, therefore water produces wood. The fluid of fire is Yin, its substance Yang. Since the nature of Yang is burning and destructive, fire cannot produce metal. As regards earth, its fluid is Yang and its substance Yin. Consequently it makes use of the Yang of fire to produce the Yin of metal.

Here we have again the mysticism of the Yiking.

Fire and earth together produce metal, and water and earth combined produce wood. In both cases earth is indispensable. When wood produces fire, and metal, water, earth is not required.

Regarded as the ultimate causes of the seasons the elements were also invested with the qualities which, properly speaking, belong to the seasons alone. These characteristic features of the seasons are, according to Pan Ku's 


\section{A. Forke, Introduction and Appendixes to Wang Ch'ung's \\ Lun-hêng}

Po-hu-t'ung: generating, growing, reaping, and hiding ${ }^{1}$. Tung Chung Shu already gave similar attributes to the elements. Wood, said he, is the generative nature of spring and the basis of agriculture. Fire is the p2.461 growing of summer, earth the maturing of the seeds in mid-summer, metal the deadly breath of autumn, and water the hiding in winter and the extreme Yin.

\section{Transformations of the Elements}

\section{a) In Heaven : the Celestial Bodies and the Five Planets}

The whole universe, the material as well as the intellectual world are nothing else than transformations of the Five Elements. The world has been evolved from the primary essences the Yin and the Yang, of which the elements are derivates or compounds.

We have seen that Kuan Tse (p. 450) joined the heavenly bodies to the different quarters : the earth to the centre, the sun to the south, the moon to the north, the stars to the east, and the zodiacal signs to the west. It is natural that the earth should be regarded as the centre of the universe and the sun be connected with the south, the seat of heat and light. The moon then had to go to the opposite direction, the north, where cold and darkness reign. Then the stars had to take the two remaining quarters, the east and west. We learn from Wang Ch'ung that in his time not only the sun was regarded as fire, but that the moon also was believed to consist of water (cf. I, p. 268 and 357). Fire being the element of the south and water that of the north, the celestial bodies were believed to be formed of the element belonging to their quarter. The Earth consists of earth, the element of the centre. Then the stars must be of wood and the zodiacal constellations, of metal.

But the combination of the Five Planets with the Five Quarters or the Five

${ }^{1}$ Kuan Tse XIV, 8v. has nearly the same attributes. 


\section{A. Forke, Introduction and Appendixes to Wang Ch'ung's \\ Lun-hêng}

Elements is much more common than that of the celestial bodies in general. Huai Nan Tse III, 3 r. seq. declares the Five Planets : Jupiter, Mars, Saturn, Venus, and Mercury to be the spirits 神 of the Five Quarters. The Shi-chi chap. 27 says that the Five Planets are the elements of the Five Quarters ruling over the Seasons, e. g.,

«Mars is said to be the fire of the south and governs summer (eod. p. 18v.). [Chavannes]

Of course one may translate that Mars corresponds to the fire, but the literal translation seems to me preferable and more in accordance with the materialistic views of the Chinese to whom Mars, the Fire Star, is made of fire, and Jupiter, the Wood Star, is made of wood. These characteristic terms of the Planets are frequently used in the Shi-chi. The Chin-shih (14th cent. A. D.) distinctly states that in heaven the fluid of the essence p2.462 of the Five Elements becomes the Five Planets, on earth, the Five Substances and in man the Five Virtues and the Five Businesses. From another modern treatise we learn that looking up to the Five Planets at dusk we see their five colours quite clearly, without the least confusion, because they are the essences of the Five Elements. Here again we notice quite analogous conceptions in Agrippa (loc. cit. p. 198), who likewise takes the planets for products of the elements. Mars and the Sun he pronounces to be fiery, Jupiter and Venus to be airy, Saturn and Mercury to be watery, and the Moon to be earthy.

We do not know which consideration led to the connexion of each element with each planet. Probably it was in the different colours of the planets that the Chinese imagined they recognised the five colours: green, red, yellow, white, and black of the elements. That at dusk we see the five colours quite distinctly, without the least confusion, as the above quoted Chinese author would have us believe, is out of the question. The ancients as well as the moderns are at variance in regard to the colours of the planets (see above $p$. 443). There only seems to be some unanimity about the red colour of Mars and the white one of Venus.

Valens goes so far as to give the reasons why the planets logically must have the colours which he assigns to them: Saturn, he says, is black, because it is Time or Kronos which obscures everything. Jupiter is radiant, 


\section{A. Forke, Introduction and Appendixes to Wang Ch'ung's \\ Lun-hêng}

because he cares for glory and honour. Venus shows various colours owing to the various passions which she excites, and Mercury is yellow, for he governs the gall which is yellow ${ }^{1}$. There arguments are very queer, but quite in the Chinese way of reasoning, and it would not be surprising to find them slightly modified, in an ancient Chinese writer.

As we have learned from Huai Nan Tse in the Chou epoch already the Five Planets were regarded as the spirits of the Five Quarters. As such they were venerated and named the 'Five Emperors'. They were distinguished by their colours as the Green Emperor = Jupiter, the Red Emperor = Mars, the Yellow Emperor = Saturn, the White Emperor = Venus, and the Black Emperor = Mercury. (Cf. Shi-chi chap. XXVIII, Chavannes, Mém. Hist. Vol. III, p. 449).

b) On Earth : the Inorganic and the Organic Kingdom ; Man.

The element earth embraces all kinds of earth and stones; metal, the various metals; so the entire inorganic kingdom is the outcome of these two elements. Of water different kinds are distinguished according p2.463 to their origin, such as spring water, rain water, water from ditches, lakes, the sea, \&c. Fire may take its origin from wood, from oil, from stones or other substances, from lightning, or it may be the glowing of insects, or a will-o'the-wisp. The whole flora belongs to the element wood which includes trees, plants, and flowers. But here we meet with a difficulty. If all plants are produced by the element wood, how is it that in the Liki the five kinds of grain : wheat, beans, millet, \&c. are connected with the Five Elements, and not with wood alone, so that beans correspond to fire, and millet to water ? A Chinese philosopher would probably reply that all these cereals issue from the element wood, but have an admixture of one of the other elements. So wheat would be wood in wood, beans fire in wood, and millet water in wood.

It would be logical, if the whole animal kingdom were classed under one chief element also, but they are distributed among the Five Elements, and it is difficult to understand the plan of this division : The scaly creatures, fishes, and reptiles e. g., snakes and dragons belong to the element wood, the shell-

${ }^{1}$ Bouché-Leclerq, Astrologie grecque, p. 314. 


\section{A. Forke, Introduction and Appendixes to Wang Ch'ung's \\ Lun-hêng}

covered or crustaceous animals : turtles, crabs, oysters, \&c. to the element water. The element earth embraces all naked creatures, among which are found toads, earth-worms, silkworms, spiders, eels, and man. Fire is the element of all feathered animals or birds, and metal, that of all hairy ones or beasts. Consequently the Five Sacrificial Animals : sheep, cock, ox, dog, and pig should be looked upon as transformations of the element metal save the cock corresponding to fire, but the Liki makes them correspond to all the Five Elements, and we would again have combinations of two elements : metal and wood $=$ sheep, metal and earth $=$ ox, \&c.

Here the views of Agrippa von Nettesheim (loc. cit. p. 198) are very instructive. He teaches us that from the Four Elements of Aristotle issue the four principal divisions of nature : stones, metals, plants, and animals. Each of these groups consists of all the elements combined, but one predominates. Stones are earthy, metals watery, because they can be liquified and by the Alchimists are declared to be the products of living metallic water (mercury), plants depend upon air, and animals upon fire, their vital force.

Among stones which as such are earthy, the opaque ones are earthy, the pellucid ones and crystal which have been secreted from water, are watery, those swimming on water like sponges are airy, and those produced by fire like flints and asbestus are fiery. Lead and silver are earthy, mercury is watery, copper and tin are airy, and iron and gold are fiery.

As regards animals, vermin and reptiles belong to earth, fish to water, and birds to the air. All animals with great warmth or with a fiery colour such as pigeons, ostriches, lions and those breathing fire, belong to this element. But in each animal the different parts of its body belong p2.464 to different elements : the legs belong to earth, the flesh to air, the vital breath to fire, and the humours to earth.

Man is treated in the same manner by the Chinese. As the foremost among the three hundred and sixty naked creatures (cf. Vol. I, p. 528, Note 2) he belongs to the element earth, but the parts of his body and his moral qualifies are connected with the different elements and produced by them. From the Liki and the Huang Ti su-wên (p. 448) we have learned the correspondencies of the Five Constituent Parts of the body : muscles, veins, 


\section{A. Forke, Introduction and Appendixes to Wang Ch'ung's \\ Lun-hêng}

flesh, skin and hair, and bones, and of the Five Intestines with the elements. An inner reason for this classification is difficult to discover, but there has certainly been one, although it may not tally with our ideas of a scientific classification.

The transition of the Five Elements from the material into the spiritual world is by some writers believed to be a direct one, whereas others see in the parts of the human body the connecting links. Chu Yung of the Sung period informs us that the Five Elements are the Five Organs of the human body, and that the fluids correspond to the Five Intestines. The Five Organs are the ear, the eye, the nose, the mouth, and the body serving to produce the five sensations. Wang Ch'ung (Vol. I, p. 194 and 381) is of opinion that the Five Virtues are closely connected with the Five Intestines which are their necessary substrata. By a destruction of these inner parts of the body the moral qualities of man are destroyed as well. According to this view the elements appear as moral qualities only after having been transmuted into parts of the human body. Other writers assume a direct process of transformation. We have seen the Chin-shih maintaining that in heaven the fluid of the Five Elements becomes the Five Planets, on earth the Five Substances, and in man the Five Virtues and the Five Businesses (above p. 462). The Taoist T'an Ch'iao (10th cent.) also merely states that the Five Virtues are the Five Elements, setting forth the following classification :

«Benevolence is equivalent to fostering and growing, therefore it rules through wood. Justice means assistance of those in need, therefore it rules through metal. Propriety is enlightenment, whence it rules through fire. Wisdom denotes pliability, whence is rules through water, and faith is the same as uprightness, wherefore it rules through earth.

The reasoning is radier weak, but we find the same distribution of the Five Virtues in the following list of the Sung school of p2.465 thought. That its classification does not quite agree with that of the Liki and the Huang Ti suwên given above is not to be wondered at, since in reality the elements have nothing to do with moral qualities, and the supposed relations are pure imagination : 


\section{A. Forke, Introduction and Appendixes to Wang Ch'ung's}

\section{Lun-hêng}

\begin{tabular}{|l|l|l|l|l|l|}
\hline Elements & wood & fire & earth & metal & water \\
5 Parts of Body & muscles & hair & flesh & bones & skin \\
5 Intestines & liver & heart & spleen & lungs & kidneys \\
5 Souls & mind & spirit & reason & animal soul & vitality \\
5 Senses & smell & vision & touch & taste & hearing \\
5 Impulses & joy & gaity & desire & anger & sorrow \\
5 Virtues & benevolence & propriety & faith & justice & wisdom \\
\hline
\end{tabular}

We have seen above (p. 443) how Ptolemy joined the parts of the body and the senses to the seven planets, and how Proclus made the different spheres of the human mind correspond to the spheres of the stars. In this respect they were only the successors of the Chaldeans and Egyptians, who first connected the parts of the human body with the twelve signs of the zodiac. A human body was thought extended over the vault of heaven, its head resting on Aries. Then its neck lay on Taurus, its shoulders and arms on Gemini, the breast on Cancer, the flanks on Leo, the stomach and the bladder on Virgo, the buttocks on Libra, the genitals on Scorpio, the thighs on Sagittarius, the knees on Capricorn, the legs on Aquarius, and the feet on Pisces. In the Kabbala the three elements, fire, water, and air were combined with the three parts of the body : the head, the breast, and the belly. The Seven Planets correspond to the Seven Orifices of the Head, and the Twelve Signs of the Zodiac to the Twelve Human Activities (p. 444). These ideas were taken up by Agrippa as appears from his table (p. 445). A similar scheme was in vogue among the Central American Mayas. (Cf. P. Carus, Chinese Thought, 1907, p. 87.) The Chinese do not lay much stress upon the relation between the parts of the human body and the planets, but it exists, since the planets are nothing else than manifestations of the Five Elements in the celestial sphere, the parts of the body, its sensations, feelings, and moral qualities being manifestations of the same elements in the human sphere.

\section{Local and Numerical Relations of the Elements}

It has been shown that at a very early date the Five Elements were referred to the Four Seasons, a fact evidenced by the Tso-chuan and the Liki. It is not difficult to guess - strict proofs we have not - how the elements were assigned to the seasons. Fire could only be joined to the p2.466 hottest 


\section{A. Forke, Introduction and Appendixes to Wang Ch'ung's \\ Lun-hêng}

time of the year, when the sun sends its fiery rays, summer. Conversely, water, considered as the extreme Yin and the product of cold, had to be combined with the coldest and darkest season, winter. Wood could serve to symbolise the new growing of the vegetation in spring, and metal the cutting of the cereals and other plants, used by man, in autumn. For earth there was no special season first.

The obvious analogy between the Four Seasons and the Four Quarters then led to the connexion of the elements with the Four Points of the Compass. Within the space of a Year the four seasons : spring, summer, autumn, and winter follow one another, and during one day the sun successively passes from the east through the south and the west to the north, to begin the same course on the following morning. What more natural than the equation :

$$
\begin{aligned}
& \text { wood, fire, metal, water }=\text { east, south, west, north. } \\
& \text { spring summer autumn winter. }
\end{aligned}
$$

With spring the new year begins, as in the east the sun begins its course ; in summer, and in the south the sun is hottest, summer being the season, and the south the region of the greatest heat ; in autumn, and when the sun is in the west its heat decreases ; in winter, and in the north the heat is gone, and we then arrive at the cold season and the region of cold. Here we have a seat for earth also viz. the centre, so that the Five Elements correspond to the Five Points. Our point of observation is the centre, and we have earth under our feet. The south is filled with the element fire, the north with water, whereas wood permeates the east, and metal the west. Facing the south, the chief direction according to the Chinese view, we have fire in the front and water in the rear, wood on our left, metal on our right side, and earth in the centre where we stand. These positions, first assigned, to the elements by $\mathrm{Ho}$ Kuan Tse (p. 446) are merely derived from their combinations with the Five Points.

The Four Quarters or, more correctly speaking, the Four Quadrants of Heaven, Sse-kung, have been symbolised by four fancy animals : the Green Dragon in the east, the Scarlet Bird in the south, the White Tiger in the west, and the Black Warrior or the Black Tortoise in the north, to which Huai Nan 


\section{A. Forke, Introduction and Appendixes to Wang Ch'ung's}

\section{Lun-hêng}

Tse still adds the Yellow Dragon corresponding to the centre ${ }^{1}$. Each of these four animals embraces seven of the twenty-eight Constellations or Solar Mansions. We find the same names in the Shi-chi chap. 27 (Chavannes, Mém. Hist. Vol. III, p. 343 seq.) and in the Lun-hêng Vol. I, p. 106 and 5342. Wang Ch'ung seems to regard them as heavenly spirits formed of the fluids of the Five Elements and as constellations at the same time. Pan $K u$ likewise speaks of the essence of these animals, but instead of the Scarlet Bird he gives the Yellow Thrush and the Phœnix ${ }^{3} \cdot$ p2.467 It is not improbable that the ancient Chinese really saw the shapes of animals in these constellations and took them for celestial animals imbued with the fluids of the four elements : wood, fire, metal, and water, for the Yellow Dragon of Huai Nan Tse belongs to the earth and is no constellation. The classes as well as the colours of these four animals harmonise with those of the Liki. The dragon is a scaly animal, the scarlet bird feathered, the tiger hairy, and the tortoise shellcovered, and their colours are green, red, white, and black like wood, fire, metal, and water. The yellow colour of the thrush and that of the phœnix or argus pheasant though not red, would still accord more or less with the colour of fire.

From the Tso-chuan and the Liki onward the Ten Stems or cyclical signs of the cycle of ten have been combined with the elements. The principle has been explained above (p. 452, note 2 ). To distinguish each of the Five Seasons of 72 days governed by one element, a couple of these signs, as they follow one another in the regular series, are used. The days are numbered by means of the sexagenary cycle, and each Season or element is designated by the two Stems beginning the compound number of the first and second day of the season. The two first days of spring are chia-tse and yiChou, therefore the whole season and its element wood have the cyclical signs chia and $y i$. The first and the second days of summer are after the sexagenary cycle a ping-tse and a ting-ch'ou day, therefore the whole season of summer and its element fire are connected with the Stems ping and ting. The second characters of the component numbers belonging to the Twelve

\footnotetext{
1 Huai Nan Tse III, 3v.

2 The translation 'Blue Dragon' must be changed into 'Green Dragon'.

3 Po-hu-t'ung II, 2 v.
} 


\section{A. Forke, Introduction and Appendixes to Wang Ch'ung's \\ Lun-hêng}

Branches, tse and ch'ou, are left out of account. So the Ten Stems : chia yi (wood-spring), ping ting (fire-summer), wu chi (earth-latter part of summer), kêng hsin (metal-autumn), jên kuei (water-winter) serve to denote the commencements of the seasons or the periods when each element begins its reign ; they are time marks so to say.

In the Liki only the Ten Stems are thus used, Huai Nan Tse, moreover, conformably to the method alluded to in the Tso-chuan, joins a couple of the Twelve Branches to the Five Elements. Their meaning is quite different, they are local marks showing the point of the compass where the respective element is located, for the Chinese denote the Four Quarters and their subdivisions by means of these Branches. According to the position of the elements, the Branches designating the east, south, west, and north points and the intermediary points nearest to these, are added to them. So we have :

$$
\begin{aligned}
& \text { wood = yin mao, E.N.E and East ; } \\
& \text { fire = sse wu, S.S.E and South ; } \\
& \text { metal = shên yu, W.S.W and West ; } \\
& \text { water = hai tse, N.N.W and North. }
\end{aligned}
$$

p2.468 With good reason Huai Nan Tse III, 17v. leaves out earth, on the ground that it belongs to all the four seasons. Earth being in the centre cannot well be combined with a sign connoting a point of the compass on the periphery. Later authors have done it all the same. Tai T'ing Huai attributes to earth the four remaining cyclical signs : shên, Hsü, ch'ou, and wei viz. E.S.E, W.N.W, N.N.E, S.S.W. If this has any sense at all, it can only mean that earth is to be found in every direction, approximately denoted by the four characters. In Couvreur's Table only the signs ch'ou and wei are assigned to earth.

It is well known that the Twelve Branches also serve to mark the twelve double-hours of the day, but I doubt whether all sinologists are aware of the reason of this peculiar use. Even when denoting the hours of day and night, the Branches have no temporal, but only a local value, marking the direction where the sun stands during a certain hour. In spring and autumn, when day and night are nearly of equal length, between 5-7 a. m. the sun stands in, or 


\section{A. Forke, Introduction and Appendixes to Wang Ch'ung's \\ Lun-hêng}

passes through mao = East, whence the hour from 5-7 a. $\mathrm{m}$. is called the mao hour. At noon, 11-1 p. m. it passes through $w u=$ South, between 5-7 p. m. through $y u=$ West, and at midnight from 11-1 a. m. the sun, though not seen by us, traverses tse $=$ North. Originally the Twelve Branches merely mark the points of the compass, their designation of the twelve hours is only a secondary use based on the course of the sun through these points.

The ordinary numerals attached to the elements in the Liki : earth $=5$, water $=6$, fire $=7$, wood $=8$, and metal $=9$ are said to refer to the 10 stages or turns in which originally the Five Elements were evolved from Yin and Yang, or Heaven and Earth. This is again in accordance with the above mentioned obscure passage of the Yiking. Tai T'ing Huai states that

$$
\begin{aligned}
& \text { 1st Heaven engendered water, } \\
& \text { 2ndly Earth engendered fire, } \\
& \text { 3rdly Heaven engendered wood, } \\
& \text { 4thly Earth engendered metal, } \\
& \text { 5thly Heaven engendered earth, } \\
& \text { 6thly Earth completed water, } \\
& \text { 7thly Heaven completed fire, } \\
& \text { 8thly Earth completed wood, } \\
& \text { 9thly Heaven completed metal, } \\
& \text { 10thly Earth completed earth. }
\end{aligned}
$$

p2.469 Now all elements are given the number of their completion : water $=6$, fire $=7$, wood $=8$, metal $=9$ except earth which bears the number of its generation, because, says a commentator, generation is the principal thing for earth. This reason is as singular as the whole theory of this creation in ten stages.

\section{The Different Modes of Enumerating the Five Elements}

There are at least four different ways of enumerating the elements, each series having its special meaning : 


\section{A. Forke, Introduction and Appendixes to Wang Ch'ung's \\ Lun-hêng}

a. The order in which the elements are believed to have originally been created: Water, fire, wood, metal, earth.

We found this series in the Shuking p. 433 and the Chi-chung chou-shu p. 437. Whether it really has the meaning disclosed by the Sung philosophers, is open to doubt. According to the T'ai-chi-t'u this series refers to the substances, showing the order in which they were produced, in contradistinction to the fluids whose successive revolutions are expressed by series b): wood, fire, earth, metal, water. Chu Hsi speaks of the order in which the Five Elements were first created by Heaven and Earth. He holds that the vague and shapeless elements water and fire came first and were followed by the solid substances wood and metal which required earth as a substratum from which they issued. But in this case earth ought to take the third place in the series and not the last.

b. The order in which the elements or their fluids follow and produce each other in the course of the seasons: Wood, fire, earth, metal, water.

This is the order of the Liki. During each season one element predominates. The others are not completely destroyed, but they have dwindled away and have no power until their turn comes, when they are resuscitated and become preponderant. The elements thus succeeding each other are said to produce one another. Both Huai Nan Tse III, 17 v. and Tung Chung Shu XI, 2 v. expressly state that wood produces fire, fire produces earth, earth produces metal, metal water, and water wood. The former regards each element producing another as its mother, the latter as is father, and the element thus generated as the son or child. According to this terminology wood for example would be the mother or the father of fire, and metal the son of earth. This analogy has induced both authors to judge the relations of the elements by the moral and the family laws, which leads to strange consequences. As men under given circumstances act in a certain way, the elements are believed to affect each other in a similar p2.470 manner. This view has been adopted by other writers as will appear from some instances given ad c.

The theory that the Five Elements produce each other in the order of this series is to a certain extent based on natural laws. One may say that wood 


\section{A. Forke, Introduction and Appendixes to Wang Ch'ung's \\ Lun-hêng}

produces fire, and fire leaves ashes or earth. In the interior of the earth metal grows, but how can metal produce water? Here is a hitch. The Chinese try to avoid it by asserting that metal may become liquefied or watery, and in this respect they are at one with Agrippa who likewise, as we saw, looks upon all metals as watery. But liquid metal is not real water, and it can never be transformed into water in the same way as wood becomes ashes or earth metal. Moreover, water alone cannot become wood, there must be earth besides - not to speak of the necessity of a germ - and to produce metal, earth and fire must co-operate. This has been pointed out in the Hsing-li h'uit'ung stating that, for the production of metal, fire and earth, and for that of wood, water and earth are wanted, so that in both cases earth cannot be dispensed with.

c. The order in which the elements subdue or overcome each other: Water, fire, metal, wood, earth.

This series occurs in the Shuking and the Tso-chuan (p. 432), and the author of the latter work knows its principle, for he informs us that water overcomes fire and fire, metal, and calls the stronger element the husband, the weaker the wife. The full list of the antagonistic elements is given by Huai Nan Tse IV, 8 v. Tung Chung Shu XIII, 5 v. remarks that of the elements in series b. those placed together produce one another, whereas those separated by one place vanquish each other. If we take the series : wood, fire, earth, metal, water, then wood subdues earth and earth, water ; fire subdues metal, and metal wood, \&c. The series must be regarded as an infinite ring ; from the last link one returns to the first.

How this mutual antagonism of the elements is to be understood we best learn from the Huang Ti su-wên :

«Wood brought together with metal is felled; fire brought together with water is extinguished; earth meeting with wood is pierced; metal meeting with fire is dissolved; and water meeting with earth is stopped.

In other words: water extinguishes fire, fire melts metal, metal cuts wood. That growing wood perforates the surrounding soil, and that earth stops the course of water, when there is an inundation for example, seems a 


\section{A. Forke, Introduction and Appendixes to Wang Ch'ung's \\ Lun-hêng}

little far-fetched, but we must bear in mind that the Chinese reasoning is not always as strict and logical as we would like to have it. The explanation given in the Huang Ti su-wên most likely completely satisfies p2.471 the Chinese mind. I would prefer the explanation of de Saussure, Toung pao 1909, p. 259 that earth vanquishes water by absorbing it ; and the same thing may be said of the relation of wood and earth, in so far as growing plants draw from the soil all the substances necessary for their development. This may be looked upon as a destruction of earth by wood.

In connexion with this theory some writers make interesting observations on the way in which the elements affect each other. Wood, says Kuan Yin Tse, when bored, gives fire, when pressed, gives water. Metal is such a substance that, when struck, it produces fire, and when melted it becomes water. The Chang-huang t'u-shu pien points out the following changes undergone by the elements, when operated upon by one another: Earth becomes softened by water and hardened by fire. Metal becomes liquid by fire and continues unchanged by water. Wood grows by water and is consumed by fire. Fire grows by wood and dies by water. Water is cooled by metal and warmed by fire. In Ch'u Yung's Ch'ü-yi shuo the action of some elements is spoken of in a way, that a tacit reproof may be read between the lines: Fire is produced by wood, but it consumes it ; metal grows in earth, but it hoes it $i$. e., both elements show a very unfilial behaviour towards their parents. Wood subdues earth, but earth nourishes wood ; earth subdues water, but water irrigates earth $i$. e., earth and water requite the maltreatment by their inimical elements with kindness. Tai T'ing Huai is quite outspoken on this subject and sets forth the curious law that, when an element is vanquished by another, its son always will revenge the wrong inflicted upon its mother element upon the aggressor and subdue him in his turn. E. g., when water overcomes fire, earth, the son of fire, will subdue water, and when fire overcomes metal, water, the son of metal, will subdue fire. There really is such a relation between the various elements according to the Chinese theory of their mutual production and destruction. This destruction is considered a natural rebuff, after an element has been produced and exceeded a certain limit, or it may have been brought about by men on purpose, in order to shape or transform certain substances, or avert calamities. Thus fire is employed p2.472 to melt 


\section{A. Forke, Introduction and Appendixes to Wang Ch'ung's}

\section{Lun-hêng}

metal and cast vessels and utensils, and earth is formed into dikes and embankments to check inundations.

In the occult arts of the middle ages the sympathies and antipathies of the elements play an important part. Agrippa (loc. cit. p. 229) contends that fire is hostile to water, and air to earth. A sympathetic action is exercised by a magnet attracting iron, an emerald procuring riches and health, a jasper influencing birth, and an agate furthering eloquence. Contrariwise, a sapphire is believed to repel plague ulcers, fever, and eye diseases, amethyst acts against drunkenness, jasper against evil spirits, emerald against wantonness, agate against poison. The panther dreads the hyena so much, that, if the skin of a panther be suspended opposite to the skin of a hyena, its hair fall out. In accordance with this doctrine of Agrippa the famous physician Theophrastus Bombastus Paracelsus, 1493-1541 A. D., based his cures on the sympathetic action of the elements. Since every part of the body pertained to a planet, all the substances belonging to the same star were considered to be efficacious antidotes against all ailments of the part in question. Gold e. g., passed for a specific against heart diseases, because gold and the heart both pertain to the sun (eod. p. 232). Even animals have recourse to this sort of cures. Agrippa relates that a lion suffering from fever cures itself by eating the flesh of a monkey, and that stags, when hit by an arrow, eat white dittany (Eschenwurz) which extracts the arrow.

d. The order in which the elements are usually enumerated at present : Metal, wood, water, fire, earth.

This series seems to be used for the first time by Pan Ku in his Po-hu-t'ung II, 1 r. I found only one attempt at explaining this order by Chu Hsi, which is very unsatisfactory. Metal, he says, is the mother of all fluids, and the body of Heaven is dry metal. Because all things begin to grow after they have received the fluid, therefore wood follows metal, \&c.

Perhaps the principle underlying this series may be that first the two substantial elements are given, secondly their two transformations, and thirdly one second transformation. Metal and wood are transmuted into water and fire, and fire again is changed into earth (embers).

Accordingly the above four orders of the elements may briefly be thus 


\section{A. Forke, Introduction and Appendixes to Wang Ch'ung's \\ Lun-hêng}

characterised :

a. series of the creation of the elements

b. series of their mutual production

c. series of their mutual destruction

d. series of their transformation.

\section{The Regular Changes of the Elements timing the Seasons}

Apart from the transformations which the elements undergo when meating, they are subject to regular modifications during the seasons, which repeat themselves every year. In the course of a year, they grow, reach p2.473 their climax, and decline again. While one element is at its height, another has fallen off, and a third is still growing. The times are usually denoted by the Twelve Branches, which, as a rule, are merely local marks. Here they are almost equivalent to the twelve months, for the sun stays about a month in each of the twelve constellations or branches which, therefore, serve to designate the months.

Huai Nan Tse III, 16 r. gives us the following comparative table :

$$
\begin{aligned}
& \text { Wood is born in hai (N.N.W. - 10th moon) } \\
& \text { Wood is full-grown in mao (E. - 2nd moon) } \\
& \text { Wood dies in wei (S.S.W. - 6th moon) } \\
& \text { Fire is born in yin (E.N.E. - 1st moon) } \\
& \text { Fire is full-grown in wu (S. - 5th moon) } \\
& \text { Fire dies in Hsü (W.N.W. - } 9 \text { th moon) } \\
& \text { Earth is born in wu (S. - 5th moon) } \\
& \text { Earth is full-grown in Hsü (W.N.W. - 9th moon) } \\
& \text { Earth dies in yin (E.N.E. - 1st moon) } \\
& \text { Metal is born in sse (S.S.E. - 4th moon) } \\
& \text { Metal is full-grown in yu (W. - 8th moon) } \\
& \text { Metal dies in ch'ou (N.N.E. - 12th moon) } \\
& \text { Water is born in shên (W.S.W. - 7th moon) } \\
& \text { Water is full-grown in tse (N. - 11th moon) } \\
& \text { Water dies in ch'ên (E.S.E. - 3rd moon). }
\end{aligned}
$$

After this scheme each element is alive nine months, and dead three months. Its body then still exists, but it is lifeless $i$. e., inactive. In the next year it is revived again, and the same process, its growing and decaying begins afresh. Each element is full-grown and shows its greatest development in the second or the middle month of the season over which it rules, wood in 


\section{Lun-hêng}

the second month of spring, and fire in the second month of summer, or the fifth month. The position assigned to earth is peculiar. It is just one month behind metal, consequently earth would govern a season almost falling together with autumn, but a little later.

Elsewhere Huai Nan Tse makes the elements pass through five different stages, adding to those given above 'old age' and 'imprisonment'. Thus we have the following comparative list ${ }^{1}$ :

\begin{tabular}{|l|c|c|c|c|c|}
\hline & strong & old & born & imprisoned & dead \\
\hline Spring & wood & water & fire & metal & earth \\
Summer & fire & wood & earth & water & metal \\
& earth & fire & metal & wood & water \\
Autumn & metal & earth & water & fire & wood \\
Winter & water & metal & wood & earth & fire \\
\hline
\end{tabular}

p2.474 Later authors go still more into details. Sun Chao of the Ming dynasty informs us that the 'Classic of Huang $\mathrm{Ti}^{2}$ distinguishes twelve changes undergone by each element during a year. He treats the elements like human beings and therefore takes the names of these changes from human life. They are : birth, bathing, being an official, a minister, a sovereign, decline, sickness, death, burial, cessation, stirring up, and growing as an embryo. Sun Chao characterises the twelve stages which follow the Twelve Branches a little differently : 1) Water exists as a sperm in sse, 2) in an embryonic state in $w u, 3$ ) develops in wei, 4) is born in shên, 5) is washed and bathed in $y u, 6)$ receives the cap and the girdle in Hsü, 7) begins its official career in hai, 8) obtains imperial glory in tse, 9) becomes old and decrepid in ch'ou, 10) sick in yin, 11) dies in mao, 12) and is buried in ch'ên. ${ }^{\mathrm{s}}$ The life of each element, its development, its acme, and its decline, in all their phases are compared to the life of man. It is washed like a baby, capped like a youth, must become an official - the ambition of every Chinaman becomes even an emperor, and then gradually declines. The same list holds good for the other elements likewise, but the cyclical signs indicating the months change. Thus fire exists in a spermatic state in hai, wood in shên, and metal in yin.

\footnotetext{
1 Huai Nan Tse IV, 9 r.

2 Huang Ti su-wên is meant.
} 


\section{A. Forke, Introduction and Appendixes to Wang Ch'ung's \\ Lun-hêng}

\section{The Element Earth and its Season}

When the Five Elements were joined to the Four Seasons, there was one element too much which could not be combined with a season. This element was earth. Why was just this one left out ? Perhaps simply hecause in the two oldest series a. and c. of the Shuking earth came last. The Chinese give other reasons. Both Tung Chung Shu X, 10 r. and Pan Ku II, 1 r. urge that earth is the noblest of the elements. Earth (the element) 上, says the latter, is but another name of the Earth 地. As such it governs the other elements and cannot be classed with them. This is true in so far as Heaven and Earth are held to have produced the elements. Besides we saw that wood and metal are believed to be products of earth, so that this element must be ranked as a sort of primary element. Though it did not produce water and fire, it supports them as it does wood and metal.

p2.475 But although there was no season left for earth, the Chinese did not like to drop this element altogether in their calendars. Since locally it was placed in the centre, they also inserted it into the middle of the Four Seasons, between summer and autumn, without attributing a special season to it. This was done in the Liki ${ }^{1}$. Subsequently earth was conceived as the element of 'late summer'. The next step was to make Five Seasons instead of Four, each of 72 days, and to assign the third, 'late summer', to earth. This step was taken by Kuan Tse (sec above p. 450) by Huai Nan Tse III, 9 v. and by Tung Chung Shu, Ch'un-ch'iu fan-lu, XIII, 9 v.

\section{The Five Elements under their Religious and Metaphysical Aspect}

The veneration of the Five Elements or properly speaking of the deities

1 Cf. Legge's translation p. 280 and 281, Note 1. 


\section{A. Forke, Introduction and Appendixes to Wang Ch'ung's \\ Lun-hêng}

presiding over the elements reaches back to the commencement of the Chou dynasty. In the Chou-li we met with the Five Sacrifices offered to the Five Heavenly Emperors, the deities of the five directions whose altars were erected in the four suburbs and the centre. They were old legendary rulers deified as the spirits of the Five Points and the Five Elements. Subsequently, they received five assistant spirits, also sons of old emperors, credited with the power of mastering the elements, and therefore revered as the spirits of the Five Elements and the Four Seasons. The spirit of Earth alone had no special season. They partook of the sacrifices made to the Five Emperors ( $p$. 434). In the Liki each season has a couple of these deities, a Heavenly Emperor or divine ruler and his attendant spirit.

The Five Sacrifices to these deities of the elements were performed by the emperor and the princes in the proper season. The Five Sacrifices of the house viz. the outer and the inner door, the hearth, the inner court, and the well were likewise referred to the five elements (cf. p. 439, Note 1). They were offered by the great officers, scholars and common people performing only one or two of them ${ }^{1}$. At the sacrifice the part of the victim which is supposed to correspond to the respective element was essential. Besides, the entire ceremonial to be observed by the emperor at these religious functions was more or less connected with the theory of the Five Elements. The hall occupied by the emperor was situated so as to be turned towards the quarter ruled by the predominating element. The colour of his horses, his flag, his robes, and his jade ornaments had to correspond to the colour of the worshipped element. His food, meat as well as vegetables, was similarly determined.

But not the religious life of the ancient Chinese alone, their political life is also overshadowed by the elements. In the Shuking already we found the statement that the good qualities of the sovereign : self possession, p2.476 orderliness, judiciousness, discretion, and sageness are related to the seasonable atmospheric influences $i$. e., to the fluids of the elements proper to the season, whereas their vices: excitement, confusion, fickleness, impetuosity, and dullness are the correlates of such fluids as are out of

\footnotetext{
1 See Liki, Legge's translation p. 225 and Lun-hêng Vol. I, p. 519.
} 


\section{A. Forke, Introduction and Appendixes to Wang Ch'ung's \\ Lun-hêng}

season. Seasonable fluids produce rich harvests, call forth a good government, and make people happy ; unseasonable ones have the opposite result (p. 434).

On the other hand, the actions of the sovereign and his administration have an influence upon the seasons and the weather, and thereby may bring down calamities upon his subjects. The Liki enumerates all proceedings which may be done during each season and which may not. The latter are not wicked in themselves, but they do not harmonise with the imaginary nature of the ruling element. In spring everything favourable to the cultivation of the fields must be done, and all destructive measures are forbidden. Trees must not be cut, young animals, birds, or insects not be killed. No warlike operations aiming at the destruction of human life are to be undertaken. The Liki points out all the natural calamities: heavy rainfalls, storms, pestilence, \&c. caused by unseasonable administrative acts (p. 439).

Kuan Tse prescribes five administrative measures for each season, the observation of which secures happiness and the accomplishment of one's desires, whereas its disregard entails misfortune. Even an eclipse of the sun and the moon and the appearance of a comet are the upshot of unseasonable

government. Since malpractices in the rewarding of meritorious actions are the cause of an eclipse of the sun, and since unjust punishments and a want of harmony have brought about the eclipse of the moon and the appearance of the comet, by removing these causes the effects are removed also ( $p$. 451).

According to the Huang Ti su-wên there is felicity only in the case that the element governing a season has its proper quantity, being neither excessive nor defective. That means to say that in summer, for instance, it must not be too hot, but not too cool either, and that in winter it must not be too cold, but, on the other side, not too warm. A cool summer and a warm winter are fraught with all kinds of evils. The vegetation suffers, and especially man is attacked by diseases (p. 449).

Tung Chung Shu, who more than others looks upon the elements as moral entities, puts forward a great variety of cases, in which the principal element of a season comes into collision with the other elements. The terminology 


\section{A. Forke, Introduction and Appendixes to Wang Ch'ung's \\ Lun-hêng}

sounds very abstract and profound, but the meaning is very simple. Tung Chung Shu wants to show the effect of extraordinary changes of the character of the seasons, one season assuming that of another and losing its own nature :

«When (in autumn) metal meets with water, fish hecome torpid ; when it meets with wood, plants and trees sprout again ; when it meets with fire, plants and trees blossom in autumn; and when it

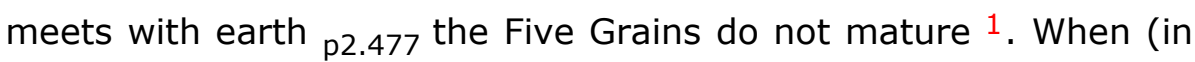
winter) water meets with wood, the hibernating insects do not hide ; when it meets with earth, the insects that ought to become torpid conte out in winter; when it meets with fire, a star falls down; and when metal meets with water, winter becomes very cold ${ }^{2}$.

Like Kuan Tse Tung Chung Shu maintains that natural calamities, the result of irregularities of the elements and the seasons, must be laid to the charge of the sovereign and his administration, and that they will cease, as soon as the latter are reformed. Thus he says of spring and summer :

«When wood undergoes an extraordinary change, spring withers, and autumn blossoms; there are great floods in autumn, and there is too much rain in spring. This has its cause in excessive personal services. Taxes and imposts are too heavy; the people become impoverished, revolt, and leave the path of virtue, and many starve. This may be remedied by a decrease of the services and a reduction of imposts and taxes, by taking the grain from the granaries and distributing it among the distressed.

When fire undergoes an extraordinary change, winter becomes warm, and summer cool. This is because the ruler is not

\footnotetext{
1 Metal is supposed to meet with the other four elements or to collide with them, as the text says. That merely signifies that, in consequence of the preponderance of these unseasonable elements, autumn changes its character and, in its temperature, resembles spring, summer, or winter. In the next clause wiuter is supposed to undergo similar changes. The consequences of these irregularities of the seasons are, most of them, taken from experience and not contradicted by facts.

2 Tung Chung Shu XIV, $1 \mathrm{r}$.
} 


\section{A. Forke, Introduction and Appendixes to Wang Ch'ung's \\ Lun-hêng}

enlightened : Excellent men are not rewarded, bad characters not removed; unworthy persons occupy the places of honour, and worthies live in obscurity. Therefore heat and cold are out of order, and the people visited with diseases and epidemies. This state of affairs may be helped by raising good and wise men, rewarding merit and appointing the virtuous ${ }^{1}$.

These ideas may seem odd, but they are not illogical. If the virtues of the ruler are manifestations of the Five Elements, an axiom laid down by the old Classics and contested by nobody, then there must be fixed relations between the two, and a change on one side affect the other. p2.478 Irregularities of the elements and the seasons must also manifest themselves in the conduct of the sovereign and his government, and any deviations of the latter, have an influence on the seasons and the weather, with which the happiness of the people living on agriculture was closely connected.

\section{Wrong Analogies}

The theory of the Five Elements is to a great extent built up on wrong analogies, but few Chinese scholars seem to have become aware of the impossible consequences to which they were led by it. Wang Ch'ung does not reject the theory altogether, but very often points out the wrong analogies, $e$. g., in the chapter on the Nature of Things Vol. I, p. 105 seq., where he says that there ought to be an internicine strife between the inner organs of man just as there is between the elements, and that the Twelve Animals corresponding to the twelve points of the compass ought to behave quite differently from the way how they do, if they were at all influenced by the elements, and in Vol. II, p. 416 seq.

In addition to this theory of the Five Elements the Chinese possess still another somewhat similar, derived from the Yiking and based on the Eight Diagrams. It is much less known and less developed than that of the Five

1 Tung Chung Shu XIV, 1 v. 
A. Forke, Introduction and Appendixes to Wang Ch'ung's

\section{Lun-hêng}

Elements, and the correspondences are quite different. The principal ones are enumerated by De Groot, Relig. System Vol. III, p. 964.

@ 


\section{Lun-hêng}

\section{APPENDIX II}

\section{The Cycle of the Twelve Animals}

p2.479 This cycle is common to the people of Eastern Asia and used by them for the numeration and designation of years. Chavannes gives a list of the corresponding cycles of the Chinese, Annamese, Cambodgians, Siamese, Chams, Japanese, Turks, Persians, Mongols, Mandshus, and Tibetans ${ }^{1}$.

In China this cycle is a correlate of the duodenary cycle of the Twelve Branches arranged as follow :

1. 子 tse, 鼠 the Rat,

2. 开 Chou, 牛 the Ox,

3. 寅yin，虎 the Tiger，

4. 卯 mao，鬼 the Hare，

5. 辰 ch'ên, 龍 the Dragon，

6. 巳 sse, 蛇 the Serpent,

7. 午 wu, 馬 the Horse,

8. 末 wei, 羊 the Goat,

9. 申 shên，猴 the Monkey，

10. 西 yu，䳽 the Cock，

11. 戊 Hsü，犬 the Dog，

12. 旁 hai, 猪 the Pig.

Wang Ch'ung (Vol. I, p. 105 seq. and 301) is perhaps our oldest source testifying to the use of this cycle among the Chinese. Since Wang Ch'ung speaks of these animals as universally known, we may safely assume that the Chinese were already acquainted with this cycle some time before Wang

${ }^{1}$ Le Cycle Turc des douze animaux in Toung pao, Série II, Vol. VII, Nr 1 (1906). 


\section{A. Forke, Introduction and Appendixes to Wang Ch'ung's \\ Lun-hêng}

Ch'ung ; say the first or second centuries B. C. (Chavannes loc. cit. p. 84). If we could trust a passage of the Wu Yüeh ch'un-ch'iu written in the 1st century A. D., it would establish the fact that the cycle was already in use about 500 B. C. The passage is plain and reasonable, but the Wu Yüeh ch'unch'iu as a whole contains so many fictions, that its testimony is of doubtful value. The statement may be reliable, but we cannot be quite sure of it.

p2.480 The cycle of the Twelve Animals cannot have been invented independently by all the nations making use of it, but must have been derived from one common source. The majority of sinologists seems to be inclined to regard it as of Turkish origin. This is the opinion of Rémusat, Klaproth, Wylie, Mayers, and Chavannes, whereas Schlegel and de Saussure have maintained its Chinese origin. Hirth advises us to be careful in asserting the non-Chinese origin ${ }^{1}$. The Chinese critics are also divided in their opinions, some look upon the Turks as the inventors, others claim the cycle for the Chinese.

Originally Rémusat and Klaproth were induced to assume a Turkish origin by their incomplete knowledge of the Chinese texts proving the existence of the cycle. They believed that it was first mentioned in the Tang-shu chap. $217 c$, p. 7 v., where it is said that the Kirghis (a Turkish tribe) were in the habit of numbering their years by means of the twelve animals. Consequently the Kirghis were credited with the invention of this cycle which the Chinese would have learned from them. But Schuyler ${ }^{2}$ informs us that it was introduced to the Kirghis from China by the Mongols, a statement for which he must have had some foundation, probably some native tradition. In that case the Kirghis themselves would decline the honour of having been the teachers of the Chinese.

Both Schlegel and de Saussure vindicate the twelve animals for China on grounds taken from old Chinese astronomy. Schlegel contends that six of the twelve animals are the well known Six Domestic Animals : the horse, the ox, the goat, the pig, the dog, the cock, and the other six have astronomical

1 F. Hirth, Nachworte zur Inschrift des Tonjukuk 1899, p. 121 (W. Radloff, Die alttürkischen Inschriften der Mongolei).

2 Schuyler, Turkestan Vol. I, p. 333. 


\section{A. Forke, Introduction and Appendixes to Wang Ch'ung's \\ Lun-hêng}

functions ${ }^{1}$. The arguments of de Saussure are not always easy to grasp, since they suppose a certain amount of astronomical knowledge which most people do not possess. He attempts to show the various astronomical, symbolical, and religious associations attached to the twelve animals by the ancient Chinese 2 .

Before entering more fully into the question we must point out a fondamental difference between the Chinese and the other nations. The latter all use the cycle of the twelve animals when numbering years, whereas the Chinese merely employ it for divination, denoting years by their duodenary cycle mentioned above. Now there are three possibilities: either this duodenary cycle and the cycle of animals are independent of one another, or the Chinese derived the cycle of animals from the Turks, or the Turks got it directly or indirectly from China.

Both cycles exactly coincide : any year bearing the first cyclical sign tse is by the Turks invariably connected with the rat, and every p2.481 Turkish dog year has in China the cyclical sign Hsü. It is highly improbable that two independent cycles should fall together, so that every new cycle begins with the same year. Such a thing is not impossible, it is true, but very improbable ; the improbahility would be 1 to 12 . Therefore we are compelled to admit an inner connection of the two cycles.

Now the Chinese duodenary cycle of the Twelve Branches reaches back to the dawn of Chinese civilisation, for we find it referred to in the most ancient literature. For the designation of years it was already used nnder the Chou dynasty. We have literary evidence showing that as far back as the 7th century B. C. the Chinese marked their years according to the position of the planet Jupiter passing through twelve constellations in the course of twelve years, the time in which this planet completes one revolution round the sun. Each year was designated by the duodenary sign denoting that part of the horizon in which the planet stayed during the year. Originally not the duodenary signs themselves but twelve other synonymous names or the

1 G. Schlegel, Uranographie Chinoise, Leiden 1875, Vol. I, p. 558 seq.

2 L. de Saussure, Les origines de l'astronomie chinoise E. Le cycle des douze animaux (T'oung-pao, Série 2, XI, 1910, p. 583 seq.). 


\section{A. Forke, Introduction and Appendixes to Wang Ch'ung's \\ Lun-hêng}

Twelve Divisions of the Ecliptic were used for this purpose ${ }^{1}$. But already in the Erh-ya of the 5th century B. C. the position of Jupiter, the year-star is marked by the duodenary cycle ${ }^{2}$. The Erh-ya being a dictionary explaining expressions of the Classics and ancient authors, its method of denoting the cycle of Jupiter must have been known prior to the 5th century, say in the 6th or the 7th. At this early time the Turks did not yet exist, not even their predecessors the Hsiung-nu ; the application of the duodenary cycle to years, therefore, cannot have been derived from them. Besides it requires much more astronomical knowledge than the Turks, who have not produced a culture of their own, ever possessed. In Chinese history the Turks do not appear before the 6 th century A. D. The cycle of the Twelve Animals is only a corollary of the duodenary cycle involving no small amount of astronomical observations. Since the Chinese did not learn it from the Turks, these must have received it from the Chinese.

The Babylonians already knew the cycle of Jupiter, and used it as early as the 3rd century B. C. ${ }^{3}$. The Hindoos also made use of it in their chronology, but there is no evidence to show that this was done before the 4th century $A$. D. ${ }^{4}$.

All chronological cycles have a beginning. They usually commence from some memorable event in the history of the people employing it. p2.482 Ulugh Beg in his treatise on the well known chronological epochs speaks of those of the Arabs, the Greeks, the Persians, the Seljuks, the Chinese and Uigurs ${ }^{5}$. The Arabs date their epoch from the Hegira, the flight of Muhammed, the Greeks from the death of Alexander, the Persians from the reign of Yezdejerd,

\footnotetext{
${ }^{1}$ See Chavannes, Mém. Hist., Vol. III, p. 654 seq.

2 Chap. 9, p. 11 seq.

3 F. K. Ginzel, Handbuch der Mathematischen und Technischen Chronologie, Leipzig 1906, Vol. I, p. 324, Note 1.

4 Lot. cit. p. 369. I do not understand what Ginzel means by saying that the cycle of Jupiter was used by the Chinese for astrology only, whereas in India the calendar was based on it (p. 493). From the 'Bamboo Annals' onward it is the basis of Chinese Chronology, all years being denoted by the sexagesimal cycle, a combination of the duodenary and the denary.

5 Epochae celebriores Astronomis, Historicis, Chronologis, Chataiorum, SyroGraecorum, Arabum, Persarum, Chorasmiorum usitatae ex traditione Ulug Beigi recensuit J. Gravius, London 1650.
} 


\section{A. Forke, Introduction and Appendixes to Wang Ch'ung's \\ Lun-hêng}

the Seljuks from the sultan Melikshāh Arslān Seljūq, the Chinese - says Ulugh Beg - from the creation of the world, in reality from the year 2637 B. C. when the sexagesimal cycle is said to have been invented by Ta Nao the minister of Huang Ti. Only in regard to the cycle of the Twelve Animals of the Uigurs Ulugh Beg states that

« with the afore-mentioned duodenary cycle the Turks deal in a shorter way. But the length of their epoch is unknown to me ${ }^{1}$.

This cannot mean anything else than that Ulugh Beg was in the dark as to the commencement of the cycle, for else he would have known its length. Ulugh Beg was himself a Turkish prince and a great scholar ${ }^{2}$. If anybody among his countrymen had been informed about this fact, he would have known it. But the Turks were not cognizant of the beginning of their own cycle or its principle. From this we infer that the cycle was not of Turkish invention, but, imported front abroad. The Turks adopted it without knowing why it was applied to the years and the twelve double hours of the day. It never quite lost its foreign character.

The Chinese have always been very slow in borrowing from other nations especially from those less civilised. Primâ facie it is much more likely that the Turks borrowed the cycle of the Twelve Animals from the Chinese than vice versa. Moreover, the combination of a number of animals with cyclical signs is quite in accordance with the Chinese way of thinking. They have symbolised the Four Quadrants or Four Palaces into which they divide the vault of heaven, by four animals : the green dragon, the black tortoise, the scarlet bird, and the white tiger, and among the numerous categories joined to the Five Elements we found the Five Sacrificial Animals : the ox, the goat, the pig, the dog, the cock (cf. p. 440), one less than the Six Animals mentioned above, which comprise the horse. The Twelve Animals of the cycle either may have only a symbolical and allegorical meaning, such as are usual in divination, or they may have been another old Zodiac of which no traces are left in literature. This view has been held by several scholars who saw in these animals old designations of the signs of the ecliptic. Ideler objects that

1 Ulugh Beg p. 50.

2 He wrote about 1444 A.D. in Transoxiania. 


\section{A. Forke, Introduction and Appendixes to Wang Ch'ung's \\ Lun-hêng}

then it would be incomprehensible how from these signs a cycle of years could have been evolved ${ }^{1}$. By no means, the cycle of Jupiter explains it most p2.483 satisfactorily. Under this supposition the ancient Chinese would have been in possession of four cycles serving to denote the hours of the day by the course of the sun, to mark the months by the course of the moon, and to designate the years by the course of Jupiter. The sun passes through each sign of these cycles in two hours, the moon in a month, and Jupiter in a year. One cycle is that of the Twelve Divisions of the Ecliptic especially in vogue during the Chou dynasty, the second that of Shê-t'i-ko mostly used in the Han time, the third the duodenary cycle now universally used, and the fourth the cycle of the Twelve Animals perhaps the oldest of all. There may be small differences between these cycles, in so far as they were referred to the heavenly equator, the ecliptic, or the horizon, but this requires further investigations by some one well versed in astronomy.

With regard to the Turkish list of the Twelve Animals we have to make the following remarks :

The Chinese Tiger is replaced by the Panther or the Cheetah, the hunting leopard = pârs [] or bârs. Now, if the Chinese had borrowed the list from the Turks, there is no reason why they should have changed the panther into the tiger, both animals being equally well known to them. Contrariwise, the tiger is very little known in Central Asia where the Turks were originally settled, though occasionally a tiger is found even there. But its home is the warmer south, India and the southern China. Consequently it would be but natural that the Turks should have replaced the tiger by the panther or cheetah better known to them, and in that case the cycle of the Twelve Animals would be of Chinese origin. Even with the panther the ancient Turks must not have been thoroughly acquainted, for their word pârs seems to be borrowed from the Persian and be the same as the Greek nápঠos and the English pard.

Vámbéry calls attention to the fact that for all the ideas referring to the higher North and its attributes, such as winter, cold, wind, snow-shoes, elk the Turks have genuine words, whereas for animals coming from the south

${ }^{1}$ L. Ideler, Über die Zeitrechnung der Chinesen, Berlin 1839, p. 80. 


\section{A. Forke, Introduction and Appendixes to Wang Ch'ung's \\ Lun-hêng}

like the goat, the panther, and others they use Persian words. By etymology he finds the regions near the sources and the upper courses of the Angara, the Jenissei, Ob, and Irtish to be the primitive seats of the Turks ${ }^{1}$.

Again, in the list of the Twelve Animals we have the Monkey, in Turkish bičin or pî́cin. There are no monkeys on the table-lands of Central Asia and, if the cycle were of Turkish invention, they would most likely not have chosen an animal alien to their own country. Being a southern animal, the monkey, likewise, was given a Persian name, for according to Klaproth pîčin would be the Persian pûjînah [] ${ }^{2}$.

p2.484 Chavannes meets these objections against the Turkish origin of the cycle by the supposition that it was invented by Turkish tribes in Gandhâra and Cashmere, referring to the Indoscythian king Kanishka of the first century of our era (p. 122). But, as we have seen, the cycle must have been known to the Chinese before this time already. Moreover, it is very doubtful whether the Indoscythians really were Turks. The language of their descendants, the Tochari, recently discovered and deciphered rather points to an Aryan people ${ }^{3}$. Chavannes seems to think of the Cakas as well, who are said to have conquered the south in the 2 nd century B. C. They may have been Turks, although this is not beyond doubt 4 , but if Chavannes supposes that the cycle of animals was known to the Turks more than 8 centuries before its first mention in the inscriptions of the Orkhon, we may make the same conjecture for the Chinese, going back 8 centuries from Wang Ch'ung's time, our earliest authority on the cycle in China. That would bring us back to the 8th century B. C., a time for which the Cakas are out of the question.

But the animal which in my opinion turns the balance to the Chinese side is the Dragon. The ancient Turks neither had the idea of this fabulous animal so intimately interwoven with Chinese mythology nor a name for it, and therefore simply adopted the Chinese name. All authorities are agreed to see

\footnotetext{
${ }^{1} \mathrm{H}$. Vámbéry, Das Türkenvolk, Leipzig 1885, p. 47 seq.

2 Cf. Chavannes p. 53, Note 6.

3 E. Sieg and W. Siegling, Tocharisch, die Sprache der Indoskythen (Sitzungsberichte der Kgl. Preu. Akad. der Wissenschaften Vol. XXXIX 1908, p. 915 seq.).

4 O. Franke, Beiträge zur Kenntnis der Türkvölker und Skythen Zentralasiens (Abh. der Kgl. Preu. Akad. der Wissenschaften 1904) p. 46 seq.
} 


\section{A. Forke, Introduction and Appendixes to Wang Ch'ung's \\ Lun-hêng}

in lui or lu the Chinese lung ${ }^{1}$. The Turks of Constantinople like the Persians replace the dragon by the crocodile neheng, and other Turkish dialects, by fish baligh. The Chinese dragon is a saurian somewhat resembling a crocodile, living in the water, but also able to fly and to ride on the clouds. The fact that the Turks borrowed from the Chinese the notion as well as the name of the dragon, an animal which plays no rôle in their life except in the cycle, this fact makes it highly probable that the Turks took the word from the Chinese while adopting the whole cycle of animals.

Ulugh Beg in his chronological work describes 5 different systems, one of them is that of the Chinese and Uigurs. The latter were, as is well known, the most civilised of the Eastern Turks. This Chinese-Uigur chronology is completely Chinese, the cycle of the Twelve Animals forms part of it, consequently the Uigurs must have borrowed it from the Chinese, as they adopted the whole chronological system.

p2.485 As a peculiarity of the Chinese and Uigur astronomers Ulugh Beg mentions that they count their civil day from midnight to midnight, whereas the Arabs, Persians, and Europeans calculate differently. Moreover, the Chinese and Uigur astronomers divide their civil day into twelve parts each of which they call chāgh, and to each chāgh they give a special name according to a series. Then follow side by side the duodenary cycle and the cycle of the Twelve Animals.

Chāgh originally means a time, a period, in this special sense a doublehour, exactly corresponding to the Chinese shih.

The astronomers again divide each chāgh into eight parts which they call keh.

This, of course, is the Chinese ko, a quarter of an hour.

The wise men of China and Turkestan have established a cycle consisting of twelve signs for the days and the years like the parts of day and night, and

1 Chavannes p. 53, Note 6 and K. Foy, Azerbajğanische Studien (Mitt. des Sem. f. orient. Sprachen, II. Abt. 1905) p. 234, Note 4.

The $\mathrm{i}$ in lui or lüi is a remnant of the nasal $n g$. The Mongols also call the dragon luu (loo), cf. Foy loc. cit.

Hirth's view that lüi would be Chinese lei (thunder) p. 119 seems to me untenable. 


\section{A. Forke, Introduction and Appendixes to Wang Ch'ung's \\ Lun-hêng}

have given it the names before mentioned $i$. e., those of the duodenary cycle and the cycle of the Twelve animals. Consequently these cycles were not only used for the notation of the double hours, but for that of the days and the years as well, and also for the months as Albiruni informs us ${ }^{1}$. In addition, Ulugh Beg proceeds, the Chinese have a cycle of ten combined with the former to a cycle of sixty, but the Turks merely use the duodenary cycle.

This shows that the cycle of the Twelve animals was a true chronological series exactly fulfilling the functions of the Chinese duodenary cycle.

If we had no other evidence, the adoption of the Chinese names for double-hour and quarter of an hour, to which must be added the expression 'intercalary' shûn = jun e. $g$. māh shūn 'intercalary month' and sāl shūn 'intercalary year', would prove that the Turks owe their chronology to the Chinese, and in this chronology just the cycle takes a prominent place.

From a study of the Turkish inscriptions Hirth (p. 126) comes to the conclusion that the calendar of the ancient Turks coincides with the Chinese and consequently, we continue, must be derived from it.

How the Turks received the Chinese calendar we learn from the Sui-shu, the official history of the Sui dynasty, when the Turks p2.486 became first better known to the Chinese. Under the reign of the founder of this dynasty Kao Tsu the intercourse with the Turks must have been very lively, for during his first years they are very frequently mentioned, several times during the same year ${ }^{2}$ :

581 A. D. in the 8th month the Turkish kagan $A$ Po sent an envoy and tribute. In the 9th month the Turkish kagan Sha-po-lio did the same ${ }^{3}$.

582 A. D. in the 4th month the great general Han Sêng Shou defeated the Turks on the Chi-tou mountain, and the minister Li Ch'ung vanquished them on the Ho-pei mountain. In the 5th month the Turks passed through the Great Wall. In the 6th month the minister Li Ch'ung defeated the Turks at Ma-

${ }^{1}$ Albiruni, The chronology of ancient nations, translated by E. Sachau, p. 83.

2 [css: cf. Chavannes, Documents sur les Tou-kiue, p. 259 seq.]

3 Sui-shu chap. 1, p. $15 \mathrm{v}$. and $16 \mathrm{r}$. 


\section{A. Forke, Introduction and Appendixes to Wang Ch'ung's \\ Lun-hêng}

$y i^{1}$ in Shansi.

583 A. D. in the 2nd month the Turks committed robberies at the frontier. In the 4th month the Prince of Wei, Shuang, vanquished the Turks at Po-tou. In the same month the Turks sent an envoy and appeared at court. In the 5th month again the generalissimo Li Huang routed the Turks at Mo-na tu-k'ou, and in the same month the commander-in-chief Tou Jung Ting defeated the Turks together with the T'u-yü-hun at Liang-chou in Kansu. In the 6th month the Turks sent envoys and sued for peace ${ }^{2}$.

584 A. D. in the 1st month a new calendar was published. In the 2nd month the Turkish Suni tribe, more than ten thousand people, male and female, arrived and offered their submission, and the Turkish kagan A-shi-na Tien with all his people did the same about the same time. In the 4th month the envoys of the Turks, the Koreans, and the $T^{\prime} u$-yü-hun were entertained at a banquet in the Ta-hsing hall ${ }^{3}$.

585 A. D. in the 5th month the great general Yuan Chi was sent as envoy to the Turkish kagan A-po. In the 7th month Sha-po-lio sent a letter to the

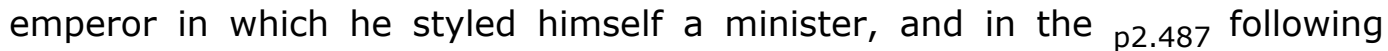
month he sent his son Ku-han-chên t'ê lo to court'. The text of the letter of the kagan has been preserved. The emperor was highly gratified by it. In his reply he said that although China entertained friendly relations with the Turks, heretofore they were two States, now there being a sovereign and a minister they were united into one. How he appreciated the new friendship appears from the fact that he had it announced in the temple to Heaven and promulgated throughout the empire. As a special honour to the kagan he resolved that in future edicts his name should not be mentioned, as the personal name of the emperor is avoided in official papers. The wife of the kagan, the kagatun, was a Chinese princess of the house of the Northern Chou, called Chien-chin kung-chu. She was received by the emperor into his own family and given the imperial family name of the Sui, Yang, and her title was changed into Ta-yi kung-chu. The son of the kagan, Ku-han-chên, was

1 Eod. p. 17r. and v.

2 Eod. p. 19r. and v.

3 p. 21 r. and v. 


\section{A. Forke, Introduction and Appendixes to Wang Ch'ung's \\ Lun-hêng}

appointed a duke of the empire with the title Chu-kuo fêng-an kuo-kung. He was feasted in the inner palace, presented to the empress, and granted rich presents in recognition of his efforts for cementing the friendship with China. The kagan, on his side, sent the yearly tribute by his son. He asked to be allowed to hunt upon Chinese territory in a certain district. Not only was this privilege granted him, but the emperor sent him wine and food for the hunt. On one day the kagan killed eighteen stags with his own hand and presented their tails and tongs as trophies to the emperor ${ }^{1}$. After all there was an intimate friendship between the two nations for the time being. Under these circumstances we are not surprised to read that in :

586 A. D. in the 1st month the calendar was communicated to the Turks ${ }^{2}$.

The T'ung-chien kang-mu chap. 36 p. 9 remarks that this was the first instance of China issuing her calendar to foreign barbarians. From that time the Chinese have always regarded the acceptance of their calendar as a sign of submission.

The cycle of the Twelve Animals forms part of the official calendar. So we find in the calendar for 1904 at the end the preceding 120 years, p2.488 all with their cyclical signs and corresponding animals, and the number of years elapsed up to 1904. Every one may look up in this list the year of his birth with all necessary particulars e. $g$. :

Kuang-Hsü 30th year, chia-ch'ên, fire, one year, dragon, male 6th mansion, female 9 th ${ }^{3}$.

Kuang-Hsü 29th year, kuei-mao, metal, two years, hare, male 7th mansion, female 8th, 5th intercalary month, \&c.

I suppose that the calendar of the Sui dynasty was similarly arranged and that at all events the Twelve Animals were mentioned, which for every one are of great importance, being believed to influence his destiny. Then in 586

\footnotetext{
1 Sui-shu chap. 84, p. 8v. seq.

2 Sui-shu chap. 1, p. 23 r.

3 The Nine Mansions into which the compass is divided. Why they are thus attributed to males and females, and what the intercalary month means perhaps Chinese horoscopists can tell.
} 


\section{A. Forke, Introduction and Appendixes to Wang Ch'ung's \\ Lun-hêng}

A. D. the Turks would have received the cycle of the Twelve Animals with the Chinese calendar.

It is possible that the ancestors of the Turks obtained a knowledge of Chinese chronology at a much earlier date, for we learn from the Shi-chi chap. 26 p. 3 v. that

« after $Y u$ and $L i$ the house of Chou begin declining : ministers of tributary States controlled the government, the astronomers did not record the seasons, and the sovereigns did not announce the first day of the month. Therefore the descendants of the astronomers ${ }^{1}$ dispersed, some in China, others among the $I$ and Ti.

From these mathematicians or astronomers the northern barbarians may have learned something about the Chinese calendar, in the 8th or 7th century B. C. and perhaps at that time already they became acquainted with the cycle of animals which subsequently became the basis of their own chronology.

That the other neighbours of the Chinese all derived the cycle of animals from China can easily be shown by the way in which they adopted the denary cycle of the Ten Stems :

The Manchus use the cycle of animals instead of the duodenary cycle like the Turks, and for the Ten Stems they make use of the Five Colours in their correct sequence, doubling each colour: green, greenish; red, reddish ; yellow, yellowish ; white, whitish ; and black, blackish. By the combination of these two cycles they form the sexagenary cycle. So they call the 11th year the green dog and the 25th, the yellow mouse ${ }^{2}$.

p2.489 The Mongols either use the Chinese Ten Stems as denary cycle, having translated them phonetically, or the Five Chinese Elements, adding either the word male or female - the Chinese yin and yang of course - or the Five Colours with a male or a female suffix ${ }^{3}$.

\footnotetext{
1 On this expression see Chavannes, Mém. Hist., Vol. III, p. 326, Note 5. One commentator explains it as 'those knowing the stars' another 'experts in chronology'.

2 L. Ideler, Über die Zeitrechnung der Chinesen, Berlin 1839, p. 83.

3 Eod. p. 85.
} 


\section{A. Forke, Introduction and Appendixes to Wang Ch'ung's \\ Lun-hêng}

The Tibetans do the same, but do not employ the Five Colours ${ }^{1}$.

The Japanese have recourse to the two Chinese cycles written with Chinese characters, but for the denary cycle they also may use the Five Elements which by the division into male and female are brought to the number of ten ${ }^{2}$.

Now, what historical evidence is there proving that the Chinese received the cycle of the Twelve Animals or other astronomicai knowledge from the Turks? None. A Turkish inscription of the year 692 A. D. is the first monument dated by means of the cycle, whereas in Chinese literature we find it universally known in the 1st century A. D. The ancient Turks were uncivilised and could not write ; the culture which they afterwards possessed they had acquired from their neighbours. Consequently they have no ancient literature, and we cannot expect any information on the origin of the soidisant Turkish cycle from this side.

The only argument of $E$. Chavannes in support of the Turkish origin of the cycle which has some weight is that the cycle of animals has been much more in vogue among the Turks and Mongols than among the Chinese, being the base of chronology of the former. It must have been invented by them, being much more inherent to their mind than to that of the Chinese who never quite assimilated it, and therefore, says Chavannes, must have borrowed it from the Turks ${ }^{3}$. De Saussure has well answered this objection ${ }^{4}$. The Chinese duodenary cycle was too abstruse for those people which, therefore, adopted it under its more popular form, the cycle of the Twelve Animals, which after all is nothing else than a category corresponding to the twelve cyclical signs. With the twelve animals they could connect same ideas, with the technical signs not. It is for the same reason that the Manchus, Mongols, and Tibetans replaced the denary cycle by the Five Colours or the Five Elements divided into male and female, yin and yang. It cannot be said that the Chinese have never assimilated the twelve animals so as to use them in chronology,

1 Eod. p. 88.

2 Eod. p. 89.

3 Chavannes p. 94.

4 De Saussure p. 638. 
A. Forke, Introduction and Appendixes to Wang Ch'ung's

\section{Lun-hêng}

because they did not require them for that purpose, having three other cycles

at their disposal. They always used them and still use them in divination, as they do most of those categories attached to the Five Elements.

@ 


\section{APPENDIX III}

\section{On Some Implements Mentioned by Wang Ch'ung}

\section{Fans}

(a)

p2.490 Wang Ch'ung speaks of fans in two places (Vol. II pp. 35 and 317 calling them by the two different names which they have in Chinese : 扇 shan and 筆 sha. The dictionary Fang-yen ascribed by many to Yang Hsiung of the 1st century B. C. states that the expression shan was in use in the regions west from the Pass, which probably means Tung-kuan where the three provinces Shansi, Shensi, and Honan meet, and the expression sha, east of it.

The Pên-tsao kang-mu infers from the character 扇 that in ancient times fans were made of feathers and bamboo for their fabrication, whence the combination with 竹 'bamboo' in the character 筆. The first conclusion seems to be wrong, for the primary signification of 栨 is not a fan, but the fold or the leaf of a folding door, a 'Thür-Flügel', 'I'aile d'une porte'. The character is a logical aggregate 會意 in which 㞋, not 犲 is the chief meaning ${ }^{1}$. The meaning fan is a derivate. It is something resembling the fold of a door in so far as it may be moved to and fro, and thereby causes wind.

In Chinese literature, and in the modern language the word 扇 shan is by far the commoner of the two.

The use of fans must have been common in China in the Chou dynasty, for our literary evidence reaches to that period. We read in Kuan Tse XIV, 9 r. about a prohibition of fans and straw hats ${ }^{2}$. That would carry us back to the

${ }^{1} \mathrm{Cf}$. the explanation given by Wieger, Leçons étymologiques p. 196.

2 Cf. above p. 450. 


\section{A. Forke, Introduction and Appendixes to Wang Ch'ung's \\ Lun-hêng}

7th century B. C. Pao Pu Tse of the 4th century B. C. says that as long as the wind does not abate, fans are of no use, and that while the sun does not appear, candles cannot be extinguished. p2.491 Huai Nan Tse XVIII, 16 r. compares certain people to those digging a well after a fire and using a fan, while wearing a fur-coat. Tung Chung Shu (2nd cent. B. C.) in his Ch'un-ch'iu fan-lu states that the dragon attracts rain, and that the fan expels heat.

In poetry the fan has been sung of many a...me, and the T'u-shu chi ch'êng and other encyclopedias contain quite a collection of such poems. The oldest and the best perhaps is the famous one on a silk fan round as the full moon by Pan Ch'ieh Yü ${ }^{1}$, aunt to the historian Pan $K u$, who himself wrote some fine verses on bamboo fans.

The material fans were made of was feathers, especially those of pheasants, peacocks, kingfishers, swans, \&c., bamboo splints, rush-leaves, palm-leaves 2, silk, paper, bark, and ivory. I doubt whether the first fans were really made of feathers as some authors maintain. A priori it is more likely that the leaves of the fan-palm were first used as fans, and that artificial fans came later.

Of the celebrated Chu Ko Liang it has been recorded that at a battle he gave his signals with a fan of white feathers, and that his army advanced or stopped accordingly.

Fans were often ornamented with precious things such as mother-ofpearl. Chao Fei Yen, the successful rival of the afore-mentioned Pan Ch'ieh Yü, who was raised to the rank of an empress by the Han emperor Ch'êng Ti, is said to have been in possession of fans of mother-of-pearl, of king-fisher feathers, and of peacock feathers.

Sometimes the handle of a fan was made of jade or precious stones. In 477 A. D. the empress-dowager prevented the vicious emperor Fei $\mathrm{Ti}$ or Ts'ang Wu Wang of the Liu Sung dynasty, a mere boy, with a fan made of

1 See my translation in 'Bluethen Chinesischer Dichtung', 1899 p.11.

2 Pfizmaier in his 'Denkwürdigkeiten von chinesischen Werkzeugen und Geräten' (Journal of the Wiener Akademie der Wissenschaften 1872, Vol. 72 p. 247-322) mistranslates this expression [] (Livistona) or [] by mallow. Mallows cannot be used for fans. 


\section{A. Forke, Introduction and Appendixes to Wang Ch'ung's \\ Lun-hêng}

feathers with a jade handle. The emperor was so much displeased with this gift, because the feathers and the handle were not ornamented, that he resolved to have the donor poisoned. He had already ordered his chief physician to prepare the poison, when he was prevented by his attendants from carrying out his wicked design.

p2.492 Silk and paper fans were often inscribed with poetry, or some picture, especially landscapes, was painted upon them. This custom prevails up to the present day. Persons proficient in calligraphy are often requested by their friends to write some lines on a fan. The Nan-shih relates a characteristic anecdote : Chêng Hsin, the son of Prince Hung of Lin-chuan, did not study as a boy. He used to carry a white round fan. The Prince of Hsiangtung wrote eight characters on the fan making fun of its bearer, who did not understand the meaning and used his fan as before.

The usual forms of fans were round like a disc, quadrangular, hexagonal, or shaped like a wing. The people of $W u$ are believed to have been the first who cut off the wings of birds and used them as fans.

In some old sources the term 'waist fan' occurs, e. $g$. in the History of the Southern Ch'i dynasty, 479-501 A. D. This seems to mean a fan hung up at the girdle. Pfizmaier calls it a 'Lendenfächer', a rather clumsy expression. This fan cannot be a folding fan as some commentator suggested, for in the 5 th century folding fans were not yet known in China.

The common name for a folding fan is chê-shan or ché-tieh shan, a fan that may be folded together. Another name is sa-shan, a fan that may be opened. The old name is said to have been chü-t'ou-shan, a fan the heads of whose ribs may be joined together. This variety of fan seems not to have been invented in China, but to be of foreign origin. All authorities are unanimous in stating that the Chinese first became acquainted with folding fans by a Korean embassy, opinions differ only about the time. The Yu-huan chi-wên, a reliable source of the 13th century, records that in the 9th month of the 6th year Hsüan-ho $=1124$, Korea sent two envoys Li Tse Tê and Chin $\mathrm{Fu}$ Chê to the Chinese court, who at a private audience brought with them 


\section{A. Forke, Introduction and Appendixes to Wang Ch'ung's \\ Lun-hêng}

three boxes of pine-wood fans and two folding fans. A verse of the famous Su Tung P'o, 1036-1101, and some other poems of the same epoch prove that from the beginning of the Sung dynasty in 960 A. D. folding fans were at least known in China.

\section{Su Tung P'o says that}

« the Korean fans of white pine wood, when spread out, cover more than a foot, and folded up, they only measure two fingers.

But though known, folding fans were not yet in vogue at this early date, and it was not before the reign of the Ming emperor Yung Lo p2.493 (14031405) that their use became common, and they soon supplanted the stiff fans. Yung Lo, delighted with the handiness of the fans, brought by the Koreans as tribute, ordered Chinese artisans to imitate them. At first it was not fashionable to use this new kind of fan, and only courtesans liked to carry them, but after some time honest women also discarded the round fan in favour of the more convenient folding fan.

It is mentioned that these folding fans are manufactured by the Japanese likewise, who make the ribs of black bamboo and bespatter the paper with gold. The author of the Pêng-chuang Hsü-lu tells us that the foreign missionary Matteo Ricci presented him with four Japanese folding fans, measuring not more than a finger when folded, very light, but strong and beantiful, and causing much wind.

In the first place the Chinese use their fans as we do for creating a light draught to cool themselves, but they also employ them as shades, holding them up towards the sun, and to protect themselves from wind and dust. In China, not only women make use of fans, but even soldiers and officers may be seen with them, and Europeans in China soon learn to follow their example.

Fans are often given by friends as a present, notably those with autographs or paintings by their own hand, a custom even followed by the emperor who may honour some subject by the gift of a fan. Some instances are given in the Yü-hai. The Yün-hsien tsa-chi mentions the fact that the people of Loyang would at the dragon-boat festival present each other with 


\section{A. Forke, Introduction and Appendixes to Wang Ch'ung's \\ Lun-hêng}

fans supposed to avert sickness.

At certain times the use of certain kinds of fans was forbidden by sumptuary laws, or at least subject to some regulations. We learn that the Han very much appreciated quadrangular bamboo fans, and that according to their ordinances the emperor took a feather fan in summer, and a silk fan in winter. The latter was probably merely decorative, whereas the feather fan produces much wind. In the time of Han $W u T i$, princes and marquises were not allowed to use fans made of pheasant feathers, and all below a duke had to use round fans. In $402 \mathrm{~A}$. D. the Chin emperor $\mathrm{An} T i$ forbade the use of silk fans and gambling.

There are some fan-like contrivances also called fans by the Chinese. The Chou-li already mentions great State fans or flabelli, and so does the p2.494 Liki. They were used in the 10th century B. C. and they may still be seen today especially at funeral processions. The Chinese name of these flabelli is sha. Couvreur has a drawing under this character. In ancient times they were carried in one of the carriages of the empress to protect her from wind and dust, and at funeral processions. In the Han time they were made of a wooden frame, three feet broad and $21 / 2$ feet high, and covered with a white stuff on which were embroidered clouds, vapours, or hatchets. At the funeral of an emperor eight big fans were used, for a great dignitary six, for a prefect four, and for a scholar two (Tscheou Li par E. Biot Vol. II pp. 126, 232). The modern flabelli are made of feathers, of painted cloth, or of wood and provided with a long stick. They are carried by the side of a coffin or a princely carriage, and after the funeral stuck into the ground round the grave.

The punkah, in Chinese, Fêng-shan 'Wind fan', of which the Europeans living in China make an extensive use, is not much appreciated by the Chinese, who seldom have it in their houses. But some kind of a punkah seems to have been known in China at a very early date. We learn from the Hsi-ching tsa-chi, a work of the 6th century, that a clever artisan of Chang-an connected seven fans shaped like big wheels, each having a diameter of ten feet. When they were moved by a man, the whole room became cool.

Another instance is given of a fan used for evaporating water and thus reducing the hot temperature. In the house of a certain Wang Yuan Pao these 


\section{A. Forke, Introduction and Appendixes to Wang Ch'ung's \\ Lun-hêng}

was a very strong skin fan. When during the hot season some guest was invited to dinner, this fan was placed in front of his seat and sprinkled with fresh water. Forthwith a cool breeze came up. As soon as the guest, white the wine was circulating, looked refreshed, the fan was removed. The emperor sent some officer to fetch this fan and have a look at it, but, though it pleased him very much, he did not keep it. He said that this fan was made of dragon skin.

This invention, now often used in our modern houses with radiators, was not utilised by the Chinese either. It was one of those good ideas they often had, but which they failed to develop and take advantage of.

\section{Chopsticks}

p2.495 The use of forks at meals is a sign of higher civilisation. Not only savages, but also highly cultured people have been accustomed to take their meals with their natural forks, their fingers. The ancient Greeks and Romans had only spoons at their banquets, but no forks. These are first mentioned by Petrus Damianus, who died in 1072 A. D. He reports that a Byzantine princess introduced this innovation in Venice. For many centuries forks were regarded as an instrument of sinful effeminacy, and it was not before the 17th and 18 th centuries that their use became general in Europe.

In China chopsticks have always taken the place of forks. Both are, so to say, artificial prolongations of the fingers, invented to keep the latter clean ; forks are stiff, chopsticks moveable fingers. The early use of chopsticks testifies to the old age of Chinese civilisation.

If we can believe a notice in the Shi-chi, chopsticks were already known under the Yin dynasty, for their last emperor is said to have employed ivory chopsticks. (Shi-chi chap. 14 and 38, Chavannes Mém. Hist. Vol. III, p. 16 Note 3 and Vol. IV, p. 216). Wang Ch'ung relates the same fact in two places, Vol. I, p. 354 and Vol. II, p. 117. Sse-Ma Chêng proposes to explain the expression occurring in the Shi-chi by ivory cups, which might perhaps agree 


\section{A. Forke, Introduction and Appendixes to Wang Ch'ung's \\ Lun-hêng}

better with the context, but chu cannot mean a cup. It is the usual sign for 管 chopsticks, for which [] and [] are also written.

For the Chou epoch the use of chopsticks is quite certain. Hsün Tse XV, $11 \mathrm{r}$. says that trees a hundred feet high seen from a mountain appear like chopsticks. The philosopher Hsün Tse lived in the 4th century B. C. Huai Nan Tse XI, 2 r. connects ivory chopsticks with mounds of dregs, referring, as the commentator says, to the extravagance of the last emperor of the Yin dynasty, Chou.

In the Han-shu chap. 40 p. 6 r. Chang Liang arrived when the emperor was at dinner. In order to demonstrate his ideas Chang Liang begged to borrow the chopsticks of the emperor. Another passage of the same historical work, Han-shu chap. 40 p. 29 r. narrates an adventure of general Chou Ya Fu who died in 152 B. C. As a joke the emperor offered him a big piece of meat to eat, but uncut, and without chopsticks. Chou Ya Fu became uneasy, and asked for some chopsticks from the emperor's table ${ }^{1}$.

p2.496 The Fei Yen wai-chuan says of Chao Fei Yen that, when she was raised to the rank of an empress, Pan Ch'ieh Yü congratulated her and presented her with various objects. Amongst these was a pair of chopsticks made of rhinoceros horn to avoid poison. ${ }^{2}$ The Chinese believe that this horn indicates whether a dish is poisonous. The new empress was very capricious. When she felt the slightest suffering, she did not eat or drink alone, and the emperor was obliged to hold the spoon and the chopsticks for her.

The Liki tells us when chopsticks may be used and when not :

«Do not use chopsticks in eating millet,

and

«If the soup be made of vegetables, chopsticks should be used ; bot not if there be no vegetables' (Legge, Sacred Books Vol. XXVII p. 80 and 82.)

The meaning seems to be that chopsticks are only to be used for solid food, whereas for soup and liquid food the spoon is the proper implement.

${ }^{1}$ Cf. Giles, Biogr. Dict., No. 462. 


\section{A. Forke, Introduction and Appendixes to Wang Ch'ung's \\ Lun-hêng}

From the characters used for chopsticks it seems that in ancient times they were mostly made of bamboo. Subsequently common wood was employed as well as bone and ivory. Tutenague is also said to be a suitable material, but gold and jade are regarded as unfit. These are the chef materials of which chopsticks are still made.

\section{Burning Glasses and Moon Mirrors}

We read in the Chou-li that the officials in charge of light received the brilliant light from the sun with the Fu-sui, and the clear water from the moon with a mirror. (Le Tscheou-li par E. Biot Vol. II p. 381.) The commentators say that Fu-sui is equivalent to Yang-sui or a burning glass or a burning mirror.

Wang Ch'ung speaks of burning glasses in Vol. I, p. 378 and Vol. II, p. 351 where he informs us that they were made by liquefying five stones on the ping-wu day of the 5th moon. If this be true, the material must have heen a sort of glass, for otherwise it could not possess the qualities of a burning glass. Just flint glass of which optical instruments are now made consists of five stony and earthy substances : silica, lead oxide, potash, lime, and clay. The Taoists in their alchemistical researches may have discovered such a mixture.

p2.497 Other authors maintain that the Yang-sui as well as the Fang-chu were both metal mirrors. The Pên-tsao-kang-mu describes the Yang-sui as follows :

«It is a fire mirror made of cast copper. Its face is concave. Rubbing it warm and holding it towards the sun, one obtains fire by bringing some artemisia near it. This is what the Chou-li says about the comptroller of light receiving the brilliant light from the sun by his fire speculum.

According to the same authority the K'ao-kung-chi states that both mirrors are made of an alloy of copper and tin. Other writers describe this 


\section{A. Forke, Introduction and Appendixes to Wang Ch'ung's \\ Lun-hêng}

alloy as 'gold and tin' or 'bronze and tin'. The fire mirror must he cast in the 5th month on a ping-wu day at noon, the moon mirror in the eleventh month on a jên-tse day at midnight. These times, the middle of summer and of winter are in harmony with the theory of the Five Elements.

The secondary names of the two mirrors show that they are looked upon

as correlates and opposites, one connected with the Yang fluid or fire, the other with the Yin fluid or water. The Yang-sui is also called [], and the Yinsui (moon-mirror)[].

It is possible that the ancient Chinese also knew burning glasses to which Wang Ch'ung refers, as well as burning mirrors. Huai Nan Tse III, 2 r. mentions both burning glasses (mirrors) and moon mirrors.

«When the burning glass sees the sun, it burns, and there is fire ; and when the Fang-chu sees the moon, there is moisture and water.

We learn from the Liki (Legge, Sacred Books Vol. XXVII, p. 449) that in the Chou period the use of the fire mirror was quite common among the people, for among other articles a son serving his parents should hang on the left side of his girdle was the metal speculum for drawing fire from the sun, and on the right, the borer for obtaining fire from wood. The commentator remarks that the son used his metal speculum to obtain fire when there was sunshine, and his borer when the sky was covered.

The Fang-chu attracting water from the moon is differently described by various authors guoted by the Pên-tsao-kang-mu under the head []. One writer holds that it is a big oyster p2.498 which, when rubbed and held up towards the moon, draws some drops of water from it, resembling dew in the morning. Another regards it as a stone, others as a mixture of five stones. We find also the explanation that [] means a stone [] and [] a pearl []. The Pêntsao-kang-mu rejects all these explanations contending that the Fang-chu was a mirror like the burning speculum, and similarly manufactured. This view is supported by the above quoted passage of the Chou-li, which expressly speaks of a mirror employed to obtain water from the moon. This very pure water was perhaps used at sacrifices. 


\section{A. Forke, Introduction and Appendixes to Wang Ch'ung's \\ Lun-hêng}

According to the Chinese theory the moon is water, consequently water can be drawn from it. As a matter of fact this is an illusion, and, if the Chinese have discovered some drops upon their moon-mirrors, they were probably dew drops.

Burning reflectors were known to the Greeks. Euclid about 300 B. C. mentions them in his works, and Archimedes is believed to have burned the Roman fleet at Syracuse in 214 B. C. with these reflectors, probably a myth. Plutarchus in his life of Numa relates that the Vestals used to light the sacred fire with a burning speculum. As the Chou-li dates from the 11th century B. C. it is not unlikely that the Chinese invented the burning reflector independently and knew it long before the Greeks. 
A. Forke, Introduction and Appendixes to Wang Ch'ung's

Lun-hêng

\section{INDEX OF SUBJECTS, INDEX OF PROPER NAMES}

(vol. I, p. 538-574; vol. II, p. 499-534):

See the image file : wangchung_lunheng_index.pdf

@ 